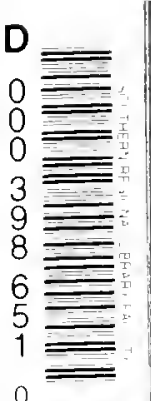

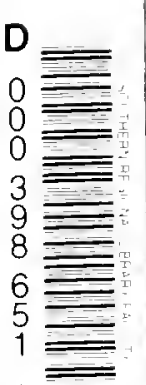

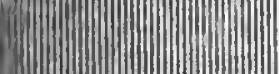




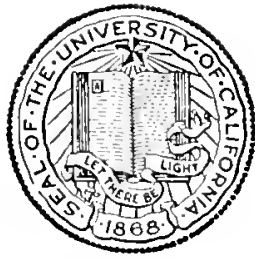

THE LIBRARY OF

THE UNIVERSITY

OF CALIFORNIA

IRVINE

GIFT OF

LEWIS HANKE 


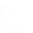






\section{LIBRARY OF CONGRESS}

\section{GUIDE}

T) THE

\section{LAW AND LEGAL LITERATURE \\ OF \\ SPAIN}

PREPARED UNDER THE DIRECTION OF

EDWIN M. BORCHARD

LAW LIBRARIAN

I3 $Y^{\circ}$

THOMAS W. PALMER, IR.

OF THE BIRMINGHAM, ALA, BAR

SHELDON FELLOW, HARVARU [NINERSITY, 1913-1914

WAMHNGTON

GOVERNMINT PRINTING OLICE

I 715 


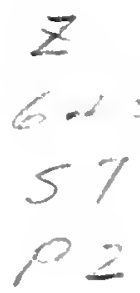

L. C. card, $15-26001$

'This rohme is for sale ly the sutemintendent of Docunents

(iovernment Printing Oflice Washington, I. C.

Price, 50 cents 


\section{PREFACE}

The I, ibrary of Congress has endea vored to neet the growing demand on the part of lawyers, legislators and students for a knowledge of the law and legal institutions of foreign comntrites by systematically acquiring the leest legal literature of the civilized states of the world. In order to make this material more readily accessible to the investigator of foreign and conparative law, the enterprise of publishing gnides to foreign law was legull.

This volume is the third in the series, having been preeded by the Bibliography of intruational law and continental laze (1913), and the Guide to the law and legal literature of Germany (1912). The Library is enabled to publish the volume at this time through the sympathetic copperation of the Harvard University Law School. The University awarded to Mr. Thomas W. Palmer, Jr. a Sleldon fellowship for the year $191.3-$ 1914 , to be devoted to the preparation of this guide. Mr. Palner spent several months in preparatory sturly in the Law Division of the I,ibrary of Congress and then visited Span, where his personal studies were aided by consultation with the foremost legal authorities of that conntry. In the plan of this work, the arrangement adopted in the guide to the law of Germany has been followed.

In the preparation of the work the thresold aim of the undertaking of publishing these guides has been preserved, namely: first, to furnish the lawyer and the student of conparative law with information as to the private and public law of the contutry; secondly, to acquaint the legislator with the recent development of legislation, particularly that designed to meet the social and econonic problens of the day; and, thirdly, to furnish the jurist and historian with a guide to the contributions to the history, theory and the philosophy of law. 
From practically all these points of view Spain offers a fruitful field for study. It possesses one of the oldest developed systems of law-a composite of Roman, Cermanic and Arabic elements, with a strong infusion of canon law; it is growing in industrial and commercial importance; it is participating actively in the legislative movement for social and ceonomic refom; and - of particular interest to us-it is the mother of the legal system of a large part of the world in which we have vital interests. In the insular possessions of the United States we have been brought into intimate contact with Spanish law and are there witnessing one of those curious and interesting phenomena of legal history, the blending of two systems of law. In Spanish-America, which socially, industrially, and commercially is awakening a constantly growing interest on the part of the United States, the seed laid by the Spanish colonizers has continued to germinate and flourish long after political cont rol ceased. The present guide. indeed, is intended to constitute the fonndation for a Guide to the law and legal literature of Latin America which is $110 \mathrm{w}$ in course of preparation.

The special thanks of the Library are dne, among others, to the following gentlemen, who by their kind and sympathetic assistance have rendered an invaluable service to the enterprise: Francisco Giner de los Rios, José Varón y Caballero, Alfonso Cabello y Guillen de Tolcdo, Felipe Clemente de Diego, Eduardo de Hinojosa, Rafacl Altamira, Constancio Bernaldo de Quirós, Fmilio Miñana y Villagrasa, Mantel González Hontoria, Marqués de Olivart, Joaquin Fernández Prida, Adolfo Posarla, Leopoldo Palacios Morini, Manuel Torres y Campos, Ramón Sanchez de Ocaña, Ramón Carande 'Thovar, Fermando Berenguer, and to various librarians, especially the librarian of the Colegio de Abogados of Madrid and the Chief of the Index Division of the National Library.

EDwin M. Borchard

Law Librarian

IILRLERT PUTANAM

Librarian of Conqress

W'ushington, D. C., December, I914 


\section{CONTENTS}

Prefier

Contents

Bibliograply

Legislation

Court reports

I $\mathrm{i} \underline{\mathrm{q}} \mathrm{p}$

General works

Legal education

Jurisprudence and philusophy of haw

Legal history

Civil corle:

History

Legislative history.

Foral systems and custunary law

Contents. .................. 45

General literature $\ldots . . \ldots \ldots \ldots \ldots$

Individual parts of the code and related sinfijects 52

Persons. . . . . . . . . . . . . . . . 52

Property-Literary and industrial property. . . 54

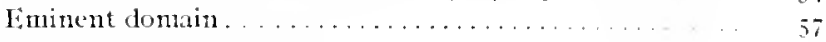

Succession and deseent . . . . . . . . . . . . . . 58

Obligations and contracts. . . . . . . . . . . . . . 50

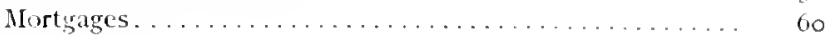

Commereial law:

Commercial ende:

Histury . . . . . . . . . . . . . . . . . . . $6_{3}$

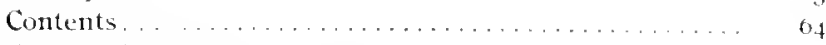

General literature ...................... $0_{5}$

Specinl and reluted subjects:

Stock exclanges................... 7o

Banking liw . . . . . . . . . . . .

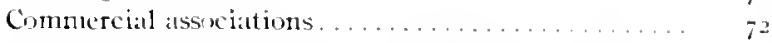

Railrouds and public service componies . . . . . . 73

Insurance . . . . . . . . . . .

Bills and notes........ ... . . . . . 70

Maritine law ......................

Consular law . . . . . . . . . . . . . . . . .

Bankruptey . . . . . . . . . . . . . . . . .

I,imitation of actions. . . . . . . . . . .

Commerciul courts . . . . . . . . . . . . . . . . $s_{1}$

Cliambers of conmerce. . . . . . . . . . . . . $\delta_{2}$

Commercial treaties . . . . . . . . . . . . . 8,3 
Civil prencedure: Page.

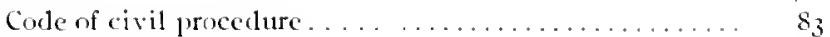

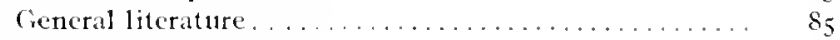

Judiciary act . . . . . . . . . . . . . . . . . $s_{7}$

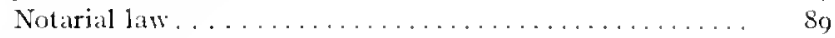

Costs and fees. .......................

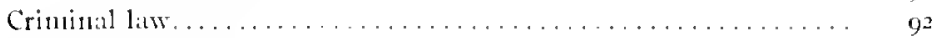

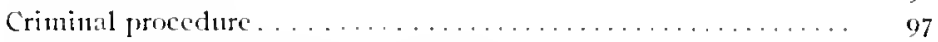

Military criminal law... ..................... 103

Crimim $\log y$ and reform of eriminal law............... 106

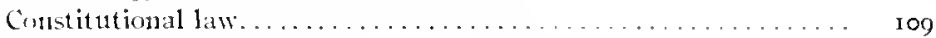

Mrministrative law....................... I1t

Nunicipal and provincial administration . . . . . . . .

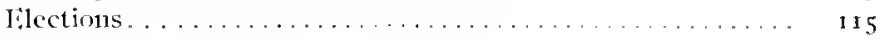

Waters . . . . . . . . . . . . . . . $\ldots \ldots \ldots$ I 5

Hunting and fishiner . . . . . . . . . . . . . . . . .

Mines. . . . . . . . . . . . . . . . . . . 116

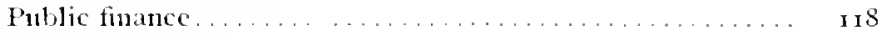

Pond liws. . . . . . . . . . .

I alor legislation . . . . . . . . . . . . . . . . . .

Workmen's insurance and employers' liability . . . . . . . . 123

Industrial conts and arbitration commissions ......... 127

Labor organizations . . . . . . . . . . . . . . . . 128

Miscellancous labor laws...................... 129

International law:

['ublic international law. . . . . . . . . .

Conflict of laws . . . . . . . . . . . . . . . . $\ldots \ldots \ldots$

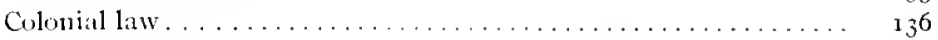

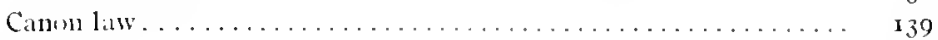

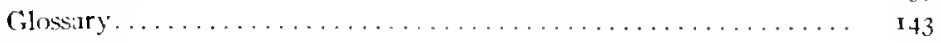

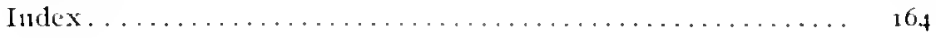




\title{
GUIDE TO THE LAW AND LEGAL LITERATURE OF SPAIN
}

\author{
BIBL, IOGRAPHY
}

The most useful bibliography of the legal literature of sipain, up to the date of its publication, is the work of 'Torres Campos ${ }^{1}$ in two volumes. Volume one extends over the period from I 800 to I 880 , and volmme two from is 880 to 1896 . 'The latter also contains useful indices, alphabetically arranged, of authors and of stibjects covering both volumes. As the author states in the introdnetion, this work is complementary to his "studies" 2 on Spanish and foreign legal bibliography which was rewarded with a golrl nedal by the Madrid Academy of Notaries in the public competition of 1876 . It also enjoys the distinction of being the first modern bibliography of its kind published in Europe. It ineludes gencral and special legal bibliographies and is arranged according to subject matter with subdivisions by "country."

The history of Spanish legal literature is discussed by Ureña ${ }^{3}$ in a learned but extrenely abstruse work publisherl in 1906. The distingnished anthor, confining himseli to a period ending at about the fourteenth century, rally presents a listory of legal science and offers a source book of carly Spanish law and legal philosophy. Useful biblingraphic notes for nearly every branch of law are included in the recent (I914) work

1 Torres Campos, Manuel. Bibliografial española contemporancal del derecho y de la pulitica. . . I ISoo-r\$SO . . AItdrid, Fernando Fé, $188_{3}$. $208 \mathrm{p}$.

Same. I881-1896. Madrid, Fernando I'é, 18198 . $168 \mathrm{p}$.

${ }^{2}$ Torres Campos, Manuel. Estudios de bibliografía española y extranjera del derecho $y$ del notariado. Madrid, Eduardo Cuesta, 1875.2611 .

${ }^{3}$ Ureña y Smenjaud, Rafael de. Historia de la literatura juridica española. zd cd. Madrid, I. Moreno, igou. $2 \mathrm{v}$. 
of Posada and other collaborators, entitled "Every day law" (infra, p. r 8).

Several Spanish legal bibliographies with descriptive notes have appeared in the English language. The "Bibliography of international law and continental law" published in Igr 3 by Dr. Borcliard" of the Library of Congress includes a section devoted to the legal bibliographies of Spain. A bibliography of early legal literature is contained in the catalogue of books on foreign law presented in 1847 by Charles Purton Cooper to the Society of Lincoln's Inn. ${ }^{2}$ Full descriptive notes are given. The lengthy introduction in Schmidt's "The civil law of Spain and Mexico" (infra, p. 37) is of bibliographic value and of especial use are the notes on the early codifications and compilations. The section on Spain by Attamira in the first volume of the Continental Legal History Series (infra, p. 36), while covering the same ground, is probably more useful and authoritative.

Kirehenheim's Centralblatt für Rechtswissensehaft, until it ceased publication in 1910 , printed annual reports of the new Spanish legal publications. Lists of new Spanish books nlay also be found in Mühlbrecht's Allgemeine Bibliographie der Staats-und Rechtswissenschaften. The reports on Spanish bibliography in the Annual Bulletin of the Comparative Law Burcau are incomplete and unsatisfactory. All the Spanish law reviews and periodicals as for instance the Revista de derecho prizado, the Revista de legislacion y jurisprudencia, etc., contain sections devoted to bibliography.

Among the various catalogues the most useful is the voluminous catalogue, published in 1908, of the Bar Association of Barcelona ${ }^{3}$ arranged alphabetically according to subject matter witl author index. The Bar Association

${ }^{1}$ Borchard, Edwin M. The bibliograplyy of international law and continental law. Washington, Government Printing Office, I913. $93 \mathrm{p}$.

${ }^{2}$ Lincoln's Inn, Society of. Specimen of a catalogue of the books on foreign law lately presented by Charles Purton Cooper. Iondon, C. Roworth and Sons, IS47. 80 p. (Spain.)

${ }^{3}$ Barcelona. Colegio de abogados. Catálogo de las obras existentes cul la biblioteca. Año igos. Barcelona, Hinrich. ${ }_{4} 86 \mathrm{p}$. 
Library of Madridt ${ }^{1}$ is at present $(1914)$ revising and enlarging its catalogue, of which the first volume appeared in 1889. The libraries of the Consejo de Estado' and of the Department of Justice ${ }^{3}$ published catalogues some years ago which still retain some bibliographic value. A recent catalogue of bibliographic interest was published by the Royal Acarleny of Jurisprudence and I.egislation; ${ }^{4}$ it eontains all the new books, both Spanish and foreign, received by its library from 1902 to 1914.

Many booksellers and publishers issue useful eatalogues of legal literature at frequent intervals. The most complete is that of Victoriano Suarez, ${ }^{5}$ a well-bound volume covering every branch of the law and conveniently indexed. The principal law publishers of Spain are Ilijos de Reus ${ }^{6}$ and Góngora $^{7}$ in Madrid. Their eatalogues also constitute useful bibliographies.

\section{LEGISIATION}

The official legislation of modern Spain may be said to commenee with the convening of the Cortes in 1810 at Cadiz during the enforced absence of Ferdinand VII. In is 2 the first constitution, which marked the beginning of the constitutional as opposed to the absolute form of the Spanish monarchy, was promulgated. Before that time the legislation consisted of nothing more than orders or edicts from the kings with codes or compilations of laws issued under royal authority. Leginning in 18 ro and continuing until 1906 , the laws (leyes) decrees

\footnotetext{
' Catálogo de la biblioteca del ilustre colegio de abogados de Madrid Vol. I. Madrid, Huérfanos, I859. 481 1).

${ }^{2}$ Catálogo de la biblioteca del Consejo de Estado. Madrid, Guildit, $187 \%$. $421 \mathrm{P}$.

${ }^{3}$ Spain. Ministerio de Gracia y Justicia. Catálogo de la biblioteca . . Madrid, Ministerio de Gracia y Justicia, 1885. $303 \mathrm{p}$.

* Catálogo de las obras recibidas por la Academia Real de Jurisprudencia y Legislación desde 1902 hasta 1914. Madrid, Hijos de Hernández. I914. $128 \mathrm{p}$.

${ }^{5}$ I,ibreria de Victoriano Suarez. Catálogo de legislación, jurisprudencia, ceonomia y ciencias sociales. Madrid, Suarez, 1913. $198 \mathrm{p}$.

${ }^{6}$ Hijos de Reus. Catálogo de las obras y publicaciones de la casil editurial de Hijos de Reus. Madrid, y gos. I 12 p. InI3 suppl. 28 I .

'Gongora. Catálogo del Centro Editorial de Góngoril. Madrid, ron 3. $881)$.
} 
(decretos) and orders (ordenes) enacted by the Cortes at the regular and cxtraordinary sessions were published officially at Madrid by the Minister of Grace and Justice. Some of the early volumes include the decrees of Ferdinand VII after his return to power. The official title ${ }^{1}$ of this collection of legislation has varied from time to time.

An index ${ }^{2}$ in four volumes covers the laws enacted by the Cortes as well as royal decrees from is $I_{4}$ to i 860 . Alarcón ${ }^{3}$ published in $185+$ a three volume repertorio of the legislation in force.

1 Colección de los decretos y órdenes que han expedido las Cortes gencrales y extraordinarias desde su instalación ... I I Io.

vols. I-2. ISIO-ISII.

v. 3-4. $18_{12-1} S_{13}$.

v. $5-6.18_{13}, 1820$

v. $7-8$. I $\$ 20-182 \mathrm{I}$.

v. 9 -10. $18 \geq 2-1 S_{23}$.

Madrid, Impr. Nacional (alsu Tomás Alban y Cua). I I $1_{3}-1823$.

Decretos del tey Fernando VII. Is $\mathrm{I}_{4}-\mathrm{I} \delta_{3} 6$.

v. I-6 with appendix. I $\&_{\text {If }}-\mathrm{I} S \mathrm{Ig}$.

v. 7-IS. IS23-I $S_{33}$.

Madrid, Impr. Real. I 8 6-1834.

Decretos de la reina isabel $I I$.

v. 19-2x. $1834-1836$.

Madrid, Impr. Real, I $8_{35}-18_{37}$.

Colección de las leyes, y decretos ... de los Cortes $y^{*}$ de los reales decretos.

v. $22-35 . \quad 1837-1845$.

Madrid, Impr. Nacional, $18,37-1846$.

Colección de legislación de Fispaña...

ง. $36-59 . \quad$ I $S_{4} 6-$ I $S_{53}$.

Madrid, Impr. Nacional, is 8 8-1 854 .

Colección legislativa de España.

v. 60-r 4 . I $8_{53}-1,8_{92}$.

Madrid, Impr. Nacional, IS5t-1 897 .

Colección legislativa de Iispaña.

v. I-23. I $898-1905$.

Madrid, Rev, de legislación, isq8-19o6.

- Colección de leyes, decretos, etc., Indices generales, cromológico y alfabético... Madrid, Impr. Nacional (etc.).

(1 $846-1860)$ Impr. Min. de Gracia y Justicia, 1862. I v.

(I $\left.8_{1}-18_{45}\right)$ Impr. Nacional, I $848.2 \mathrm{v}$.

$\left(18_{37}-18_{54}\right)$ Impr. Nacional, I854. I $\mathrm{v}$.

${ }^{3}$ Alarcón, P. A. de. Repertorio de legislación vigente.. Madrid, Tejado, $1854.3 \mathrm{v}$. 
The Gaceta de .Madril, published daily wuder the direction of the Minister of the luterior, is the official gatzette or bulletin of the governument. In it appear the laws, decrees and orders of the government as enacted and issued, as well as judicial decisions of the Suprene Court and public notices of interest to julges, courts and the local governing loodies.

flue collection of statutes currently used by practitioners is published privately in signatures by the Rerista de ligislacion y jurisprudencia. 'This publication contans, in addition to the texts of the laws, decrees, ete., a section devoted to bricf notes or discussions of legislative problems and other iteus of interest to the subseribers. It was begun in 1854 and ran contemporancously with the ollicial reports. A general index or repertorio to this series was published by Ranos? in I 882 covering the years $185+$ to 1882 . Volumes ro5-117 (1898-1902) have also been indexed tunder the direction of the editors of the Reviste. ${ }^{3}$

Another private collection was connuenced in i 897 by the Revista de los tribunales y legislución unizersal, edited by firueisco Lastres, under the title anurio de legislacion $y$ jurispradencia espanolas. Sixteen antual volumes were published up to 1913. It may be said that this publication includes both eurrent legislation and court reports. The Sevilu de los tribunales y legislacion unicersal (infra, p. 17) publishes the texts of and criticisms upon the important statutes. Under the direction of the Revista de los tribunales ${ }^{4}$ a collection of the Spanish legislation las been compiled covering the statutes from 1878 on. It is published currently. The title of the work is Repertorio de logislacion espanda but it is in fact a collection of the texts, with conplete indices appended.

${ }^{1}$ Colección completa de la legrislación española . . desde 185.3. Boletín de la Revista general de legislación y jurisprudeneia. Madrid, Rev. de legislación, $\mathrm{IS}_{54^{-19} \mathrm{I} 3}$. I52 $\mathrm{V}$.

2 Ramos, Rafaet. Repertorio general de la legislación espanola. Indice sistemático ded Boletín de . . descle $185+$ hasta $188_{2}$. Mladrid, Rev. de legislacion, $1882.762 \mathrm{p}$.

${ }^{3}$ Repertorio por orden cronológion y alfabitico... de 1998 at 1902. Madrid, Rev, de legislacion, 100.4. 059 p.

4 Repertorio de legislación españoli publicaro por la Revista de los tribunales y de legislación universal. Mliclrid, Gúngora, IS81-1913. $35 \mathrm{v}$. 
Attention may also be called to the guide or index (diccionario-guia) published by Gómez Herrero ${ }^{1}$ in which, under an alphabetical subject arrangement, the statutes are listed. The legislation indexed covers the period 1808 to 1900. A useful index in two volumes of all the legislation published officially from 1810 to 1859 was published in 1860 by Caso. ${ }^{2}$

Collections of legislation on special branches or subjects are mentioned under their appropriate headings (infra). The current legislation of Spain is reviewed in a fragmentary way in the Annual Bulletin of the Comparative Law Bureat of the American Bar Association. It may be noted also that the Revista de legislación unizersal y jurisprudencia española contains a monthly summary of current Spanish legislation.

\section{COURT REPOR'TS}

Judicial decisions (sentencias) in Spain, collectively called jurisprudencia, are not binding precedents, although they possess great persuasive force. They were formerly a direct source of law, but the present civil code (art. 6, section 2) in summing up the recognized sources of law omits judicial decisions. In default of express legislation, primarily local customs, and secondarily general principles of law, govern. But the change from a direct to an indirect source of law has had little practical effect on the influence of decisions upon the courts. The decisions interpreting the codes and stat utes are said to be strictly adliered to and contradictory interpretations not to be countenanced by the Spanisl courts, but on examination of the reports of many years such conflicting decisions are found not infrequently. Only the reports of the Supreme Court are published and these only constitute jurisprudencia.

The Supreme Court (Tribunal Supremo), the indirect successor of the Consejo ral de Castilla, was created by the Cortes of Cadiz through article 259 of the Constitution of I 8 I2. It experienced the same vicissitudes, however, through

${ }^{1}$ Gómez Herrero, Teodoro. Diccionario-gnía legislativo español. Madrid, Ricardo Fé, 1 $\$ 90-1903$. 5 v. and 2 suppl.

${ }^{2}$ Caso, José Indaleco. Guía legislativa. Indice general de las leyes, ete., en la colección legislativa oficial de España desde is 8 o liasta el día... Marlrid, Alejandro Gromez Finentenebro, I859-1860. $2 \mathrm{v}$. 
which the Constitution passed and it was not until 1834 that it was finally organized. The Supreme Court ${ }^{1}$ published in I 909 a brief sketch of its history and the names of all its judges sinee 1812 . Oficial reports ${ }^{2}$ were published from the year 18,6 to 1904 . Beginning with $187+$ the civil and criminal reports are issued separately. The reports are to-day published officially in the Gaceta (supra, p. 11), which is bound and kept in all the law libraries. Because of the unwiekliness of these reports, however, the privately issued collections are preferred.

The Supreme Court from its establishment to i 875 had a special clamber, sala, for appeals against the administration. In 1875 this judicial power was conferred on a division or committee of the Council of State, which eventually (188S) becane the Tribunal contencioso-administrativo del Consejo de Estado. This existed until $190+$ when the Tribunal contencioso-administrativo was made the present third sala of the Suprene Court, with the sane jurisdiction. 'The decisions and decrees of the Council of State ${ }^{3}$ were published officially from i 860 to 1903 under the title first of sentencias of the Council of State, and later as jurisprudencia alministrativa. These volumes are individually indexed both chronologically and alphabetically.

A complete and important collection of reports is edited privately by the Revista de legislacion $y$ jurisprudencia in loose sheets appearing monthly. These reports are issued contemporaneously with the official reports and are now used by the profession to the same extent as the official reports.

1 El tribunal supremo. Notas relalivas á su origen y vicisitudes y relacion de su personal desde isi2. Madrid, Fortanet, igog. $97 \mathrm{p}$.

2 Colección legislativa de lispaña. Sentencias del Tribunal Supremo de Justicia. Madrid, Ministerio de Gracia y Justicia, $18.46-1 S_{74}$. So $\mathrm{r}$.

Same. Materia civil. Madrid, Ministerio de Gracia y Justicia (ete.), I874-190.4. $55 \mathrm{~V}$.

Same. Materia criminal. Madrid, Ministerio de Gracia y Justicia (c1c.), is $74-1004.56 \mathrm{r}$.

(From is95 to inot the reports were published by the government in the publishing house of the Revisua de legislación.)

${ }^{3}$ Colección legislativa de Iispana. Sentencias del Consejo de Estado. (ctc.). Madrid. Ministerio de Gracia y Justicia (etc.). IS60-1903. 
The civil reports ${ }^{1}$ begin in 1838 , the criminal 2 in 1870 , and the administrative ${ }^{3}$ in 1850 . Reports of civil and administrative law are likewise issued in the form of fortnightly advance sheets by private publishers in Madrid (La jurisprudencia del dia). This constitutes a useful addition to the practicing attorney's library and is extensively used.

The Revista de los tribunales published separately up to I 894 lengthy digests of the civil (1839-r904, 20 rols.), criminal (1870-1894, 2 vols. 12 app.), and administrative (1 $880-1894$, I2 vols.) decisions of the Suprene Court, and also those involving mortgages (1 $874^{-1} 894$, I I vols.). From 1894 to 1914 all branches appear together in twenty volumes. The doctrines established by the court are given clearly and concisely. The Revista publishes the digests weekly as a detachable section of the periodical.

The reports have been indexed or digested in whole or in part in the separate divisions. Pantoja published a repertwio of the civil reports in 4 wo volumes with four appendices extending over the years $18_{3} 8$ to $188_{7}$. The work has appeared in a third edition. The period from i $\$ 83$ to 1909 has been covered by the editorial board of the Revista de legisla$\operatorname{cion}^{5}$ under the direction of Eduardo Dato, formerly Minister of Grace and Justice and now president of the Consejo de Ministros. This is designed more especially for the use of the subscribers of the reports published by the Revista de legislacion. The criminal law reports from the establishment of the speciat criminal chamber of the Supreme Court in 1870 until

- Biblioteca juridica de la Revista general de legislación y jurisprudencia. Sección de jurisprudencia civil. Madrid, Rev. de legislación, $1838-1913 . \cdots, 123 \mathrm{v}$.

2 Biblioteca jurídica de la Revista general de legislación y jurisprudencia. Sección de jurisprudencia criminal. Madrid, Rev. de legislación, I870-1913.-. S8. v.

"Biblioteca jurídica de la Revista general de legislación y jurisprudencia. Sección de jurisprudencia administrativa. Madrid, Rev. de legislación, $1850-1913 .-$. 81 v. [volumes 33-to have never been publishedl.

${ }^{4}$ Pantoja, José Mlaría. Repertorio de la jurisprudencia civil española

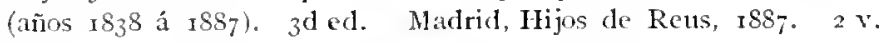
4 app.

${ }^{5}$ Repertorio doctrinal y legal de la jurisprucencia civil (años ISS3 á 1909) por la Redacción de la Revista general de legislación y jurisprudencia. zd ed. Madrid, Hijus de Reus, 1912. $6 \mathrm{v}$. 
I882 were digested in five volumes by Pantoja. The administrative law reports fron i $\$ 46$ until the abolition of the contentious administrative juriscliction in i 868 were digested by Pantoja, ${ }^{2}$ and from the establishnent of the Contentious Administrative 'T ribunal in 1888 until 1904 by the board of the Revista de legislacion ${ }^{3}$ under the direction of Fiduardo Dato. This likewise is designed as an aid in using the reports of the kezish de livislacion. The reports of the special administ rative court from the date of its organization to 1896 were oflicially digested. ${ }^{*}$

There are several collections and digests of decisions on specinl branclies of the law or interpretations of codes, e. g., commercial law, the civil cole, che. These publications are cited under their appropriate headings.

An extensive digest of reports from 18,38 to 1887 in the form of an encyclopedia of the points of law raised and decided in the Supreme Court was compiled by SienzHermua." The work is especially arranged with reference to the civil code, although supplenents cover criminal and administrative law.

\section{GENIERAI, WORKS}

There are several extensive general encycogedias and dictionaries of Spanish law. An encyclopedia pullished in 1864 by a socicty of lawyers and writers, mnder the direction of Sanguineti, ${ }^{6}$ purports to be a general compilation of all the

I Pantoja, José Maria. Repertorio de la jurisprudencia crimirtal. Madrid, Hijos de Reus, $1875-1885.5 \mathrm{v}$.

${ }^{2}$ Pantojı, José Maria. Repertorio de li jurisprudencia actuinistrativa (años s 8.46 á s868). Matrid, Hijos de Re11s, 1860). 1600 p.

${ }^{3}$ Repertorio doctrinal por orden alfabéticu de $l_{i}$ jurisprudencia administrativa española por la Redaccion de la Revista de legislación bajo la direccion tel Fiduardo Dato. Madrid, Ilijus de Rens, I8S8I904. $2 \mathrm{~V}$.

* Repertorio alfabético por materias de todas las sentencias y autus dietados por el Tribunal de lo contencioso-administrutivo desde st creación hasta el dia 15 de 1806 . Madrid, Rev. de legisliteion, r\$g6. $659 \mathrm{p}$.

${ }^{5}$ Sácnz-Hernúa y Iispinosa, P. Diccionario recopilathr de los pruntes de derechn resueltus an sentencias det Tribunal Supremn de Justicia

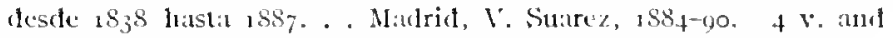
3 suppl.

o Samguncti, Carlos Massa. Diceimario jurílico-achninistrativo... Hadrid, Rev. de legislación (ete.), $1858-1864.5 \mathrm{v}$. 
laws. Escricle ${ }^{1}$ in ${ }^{8} 8,1$ published a general encyclopedia of the legislation and court reports, which, in its later editions, is still cited as authority in Spanish-American courts. In this work he was assisted by some of the leading jurists of Spain. A lengthy and ambitions legal encyclopedia was begun in $18+8$ by Arrazola, ${ }^{2}$ a Justice of the Supreme Court, in collaboration with many others. By 1870 twelve rolumes had appeared, but only the first three letters of the alphabet lad been covered. The work has never been completed. The latest legal encyclopedia is now in course of publication under the direction of Pedret, Oliver Rodríguez, and Torres Ballasté. ${ }^{3}$ Eight volumes and two appendices have appeared, but they cover only a few letters of the alphabet. This work when completed will be an exhanstive repository of the law, on the order of Fuzier-Herman's Répertoire for France. It gives defintions, expositions, and even the full texts of the important statutes. In the useful three-volume work of Martinez Moreda, ${ }^{4}$ published in 1905 , the legal terms and words ordinarily used are defined, especially those dealing with civil and commercial law. As it is inexpensive, it is widely used.

Martinez Aleubilla ${ }^{5}$ has furnished what is probably the most extensive and what has become the standard cneyclopedia of Spanish law. The work originally comprehended nine rolumes, but new appendices are constantly published. The publishers announce that a new edition condensing the appendices is now ( 1914$)$ in conrse of preparation. Alen's ${ }^{6}$ dictionary of

${ }^{1}$ Esscrielne, Joaquin. Diccionario razonado de legislación y jurisprudencia. Nueva ed. Madrid, Fduardo Cuesta, $1874^{-1} 8_{7} 6 .+v$. rst ed Paris, 183I; ad ed. Madrid, I839-1840; 3d cd. (with suppl.) Madrid, $1 S_{47}-1851$.

2 Arrazola, Lorenzo (and others). Fuciclopedia española de derecho y administración ó nuevo teatro universal de la legislación de España é Indias. Madrid, Rev, de legislación, (ete) 18+8-1870, 12 v.

${ }^{3}$ Pedret y Torres, Victor; Oliver Rodriguez, Finrique; and Torres Ballasté, Juan. Enciclopedia juridica española. Barcelona, Fran cisco Seix, IOIO-IOII. $8 \mathrm{Y}$. and 2 app. through 1912.

4 Martínez Moreda, Mateo. Diccionario de legislación vigente. Madrid, Felipe González Rojas, I905. $3 \mathrm{v}$.

${ }^{5}$ Martíncz. Alcubilla, Marcelo. Diccionario de la admitnistración española. 5th ed. Madrid, Administración, 1892-94. o v. and $2 \mathrm{I}$ pendices througli IOI2.

- Alen y Carrera, Matuuel. Diccionario de la administración municipal de España. zd ed. Madrid, A. Peréz y Cis, rgos-ri. 8 v. 
mumicipal administration erecupies a broader field than the title indicates and is a work of much practical use. The editors ${ }^{1}$ of the Gaceta have published an encyclopedia of law, with commentaries on all legislation to r 907 . Three supplements extend the work throngh $19 \mathrm{ro}$. There may also be mentioned Hermur Lspinosa's diccionario of the law as ereated by jurlicial decisions extending over the years 1838 to 1 soo.

The leading general periodieals of Spanish law are the Revisla de levislacion y jurisprudencia and the Rezista de los tribundes, both published in Madrid. The former was established in 1852 by Reus, and is now direeted by the well known jurist and publicist, Eduardo Dato. Both journals have as contributors the leading jurists of the country. Articles on subjects of legal interest and discussions of points of law are included as well as acconnts of new legislation and recent important decisions. Prof. Clemente de Diego of the University of Nadrid with the collaboration of Jose MaNavarro de Paleneia established in 1913 a new legal periodical (Revista de derecho privalo) devoted exelusively to the study of practical questions in Spanish civil, mercantile and adninist rative law. It has enjoyed a remarkable snccess in its first year of existence. Another new general law magazine (Juris) appeared in Jannary, 1914, edited by Ednardo Barriobero of Madrid, a lawyer of reputation and a member of the Cortes. Its published numbers have received some adverse criticism.

A pretentions enterprise was begun in $188_{5}$ by Romero and Gareía Moreno, ${ }^{3}$ assisted by many lawyers and publicists, with the purpose of collecting and compiling the texts of the laws and codes of the nations of modern times. Appendices

${ }^{1}$ Nuevo y completo diccionaris alministrativo . . por la Redacción de "Gaceta Administrativa." Madrid, Gaceta Adm., roı. 3 v. with 3 suppl.

${ }^{2}$ Hermur Fspinosa, Pedro Sáenz. Iniccionario recopilador de los puntos de derecho resueltos en sentencias del tribunal supremo de justicia desde 1835 hasta fin de Dicicmbre de 1895 . Marlrid, Huéranos, 1886-1800. $+v$ and 3 alp carrying the work to rsoo.

${ }^{3}$ Romero y Girún, Vicente and Carcía Moreno, Aleju. Colecciún de las instituciones politicas y juridicas de los pueblos modernos. Madrid,

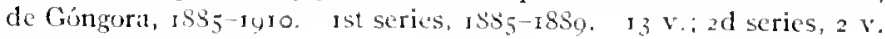
and Io aple.

$772391^{\circ}-15-2$ 
have extended the work to ig10. It may be noted that two cutire volumes are given over to a commentary on the Spanish civil code. An extrencly useful and interesting book entitled "Every day law" (Dercho usual) was published in $1913^{-1}+$ by 'osada ${ }^{3}$ with the object of presenting in language intelligible to the layman a brief exposition of all branehes of the law. Posada contributed sections on "general ideas of law," political and administrative law, social and labor laws; Clenente de Diego, Sclia, Bernaldo de Quirós and Sangro prepared the seetions on eivil, mereantile, international, eriminal and procedunal law respectively.

A treatise for the practical use of nembers of the clergy covering eivil, procedural, criminal and administrative law was prepared by Pellicer. ${ }^{2}$ A second edition was published in 1910 .

There are several publishing houses in Spain which regularly issne mannals and annotated editions of all the codes and important statntes, revising them as changes in the law may requite. Hijos de Rens and the Centro Editorial de Góngora of Madrid are the chief and most reliable of such establishments. MI. Soler of Bareelona edits convenient pocket mantals on every branch of the law. Abella, the director of El consultor de los ayuntamientos y' de los juzyados municipales of Nadrid, who publishes the most complete collection of manuals and annotated texts in the field of administrative law, edits most of the codes and other laws as well. 'Two lawyers of Madrid, L.cón Medina and Manuel Maranón have compiled annotated collections of legislation ineluding civil, eriminal, administrative and special laws. These collections are the ones currently employed by the profession. It may also be mentioned that J. Vila Serra of Valencia publishes small editions of the codes, varions manu's's and collections of special statutes and laws.

${ }^{1}$ Posada, Adolfo; Clemente de Diego F.; Sela y Sampil, A.; Bernaldo de Quirús C.; Sangro, P. Derecho usual. Madrid, La lectura, 1914. ${ }^{2} \sigma_{7} \mathrm{p}$.

2Pellicer y Guít, José. Tratado teórico-práctico de derecho civil, procesil, penal y administrativo para uso del clero. $2 d$ ed. Zaragoza, Cecileo Gasca, roro. $2 \mathrm{v}$. 


\section{IRCAI, LDUCATION}

The subject of legal education in Spain has never attracted much attention. While the overerowded law sclools conprise the largest departments of the universities, little or no modern literature has appeared in regard to the prelininary traning of lawyers and the general advancenent of the

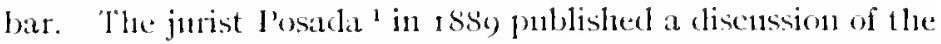
teaching of law in the Spanish universities and advanced sonte ideas for its reformation. The education of applicants for the bar and the social standing of the Spanish lawyer of the first half of the nincteent h century are described briefly in an carly number of the Law Magazine, volune 13 ( 1835 ) pages $306-309$. For purposes of comparison there may be noted an article in the July (I914) issue of Case and Conment, volume 21, pages 142-143, on legal edncation in Spain at the present tine. A brief acconnt of the existing state of legal education and the requirements for admission to the bar in Spain and in Porto Rico was presented by a Porto Rican attorney, RodrignezSerra in an address before the Anerican Bar Association in 1910, and reprinted in the Report for that year, rolume XXXV, pages $840-845$.

Altamira las discussed the state of the teaching of the history of Spanish law in the roog Bulletin hispanique, volume I 1, pages 172-199. Numerous articles of more or less interest by varions authors may be found in the Revista de leyislarion. and the Revista de los tribunales in regard to legal education in general and to the teaching of special branches of law.

\section{JURISPRUDENCE AND PIILLSOPHY OF LAIV}

The Spanish word jurisprulencia, as defined by a leading Spanish dictionary (Aleu), is the practice or custom (habito) of interpreting rightly the laws and of applying them opportunely to the cases that arise. It is used also to denominate ats a whole the decisions (scnlincias) of the suprene Court. But a broader neaning is of ten applied-the science of law or general jurisprudence, a conception better known to the AngloAnerican lawyer.

${ }^{1}$ Pusala, Adolfo. Ia enseñanza del derecho en las miversidades. Madrid, lie, rsso. I $30 \mathrm{p}$. 
Four great cpochs may be said to mark the growth and progress of the study of the science of law and its closely related subject, the philosophy of law in Spain-the early or primitive period, the Renaissance, the period of the influx of the French encyclopedists, and finally the Constitntional perind of the igtli contury cxtending to and inchinding the present day.

little is known of the early or first epoch. Tlie solumes of San 1sidoro" (570-63(1), "Libri stntentiurum" and "Ety'mologiarm libri", of the collection of his works edited by $\mathrm{I}$. Arevalo, have given hin proninence in the field of jurisprudence. The Catalan jurist, Rainundo Ltulio, nuay also be mentioned as of inportance during the primitive period, althongh he lived several centuries later than Isidom.

During the perind of the Renaissance nnmerous legal therrists and philosophers appeared. One of importance was Francisco de Vitoria" ( $+480-\mathrm{r} 546)$, whose influence was felt in the field of international law as well. The sections "De civile potestate" "DE potestate pontificis", and "DE Indis ct jure belli" in the work "Relectiones theologicae XIII" are of especial worth. Vives ${ }^{3}(\mathbf{I}+92-1540)$ made several contributions to the literature of the period, anong which may be enumerated "De causis corruptarm artium", "De comunione rerum, principes Germanice inforioris", "Praclectio in leges Ciceron is", and "Didisciplinis", collected with other monographs in eight rolumes. Mariana's work concerning the king and the institution of kingship has appeared in three Spanish cditions. Suarez, a Jestuit, suins tp with the greatest completeness and elaboration the scholastic doctrines of the law in a work published in 5613 . It has undergone many editions of various worth. An "idea of a politic-Christian prince represented in a htundred undertakings", ineluding introductions to the poliey and prineiple of the state, is an interesting subject treated by

1 Isidoro, San. Opera omnia, ... de Faustino Arévalo . . propitiones, notas, collationes. Rome, Aut-Fulgoni, 1797-I803. ro v.

${ }^{2}$ Vitoria, Franciseo de. Relectiones theologicae XIII partibus per varias sectiones in duos libros divisae. Salamanca, i 565 by P. Af. Muñoz, his diseiple. Madrid, M. Martin, $-67.607 \mathrm{p}$.

"Vives, Inis. Opera omnia. Valencia, Bened, Monfort, r $72-0.8 \mathrm{v}$.

4 Mariana, J. De rege et regis institutione. Toledo, Pedro Roderico, I $500.446 \mathrm{p}$.

sSuápez, F. De legibus ac Deo legislatore. Salamanea, Gómez de Lonreyro, I6I2. $1266 \mathrm{p}$. 
Saavedra Fajardo,' a writer of some reputation. Gracian's" works, "The discreet", "The hero", "lhe political Fernando", and the "Mamul oracle and ant of prutence", are worthy of reference. A list of the writers of this epoch woukd be incomplete which does nol mention the nimes of Cines de Sepulleda, Vazque\% Manchaca and Baltasar de Ayala.

'Foward the second half of the eighteenth century' the influence of the French encyelopedists dominated legal seience in Spain. A few representatives of the old traditions remained, among others fiather Ceballos and liather Alvarado. The change of the attitude of the Chureh from the liberalism of the middle ages to the eighteenth century absolutism seens to have had the reverse effect upon the jurists, who turned from absolut ism to liberalism.

There are a few valuable contributions to legal literature during this period. The Count of Camponanes " published in $17^{88}$ a discussion of the "impartial suit over the cedesiastical monition of Parnia" and an earlier treatise on the royal rights of mortmain in 1765 . Jovellanos ${ }^{4}$ in ${ }_{17} 87$ prepared a discussion of the agrarian law (published 1795) which, as well as his article in defense of the Central Council, is of some merit. of especial interest are his political ideas expressed in the second part of the last-named article. Martinez Marina ${ }^{5}$ has

1 Savedra lajardo, I), de. Idea de un princige politico cristiano repre. sentada en cien empresas. Last cd. Valencia, Salvador Jauli, I8001801. $2 \mathrm{v}$. [Ist ed. Monaco, Nicolas Eurico, 16.7o. $753 \mathrm{1}$.]

2 Gracian, Baltasar. Iil discreto. Barcelona, Juan Deden, $1647.3881 \%$

Same. El heroe. Amsterdam, Diego Dial, I639. $7+7$ 1)

Same. El político Don liernando. Huesca, Juan Nogues, 1644. 2221 .

Same. IAl oráculo manual $y$ arte de la prudencia. I,isboa, Henrique Yalente de Oliveiva, $165 \%$. $272 \mathrm{1}^{\text {. }}$

3 Campomanes, Conde de. Juicio imparcial sobre el nonitorio de Parma. Madrid, 1788 .

Same. Tratado de la regalia de amortización. Macirid, 1765.

* Jovellanos, Gaspar Melchur de. Informe. . en el experliente de la ley agraria . . Madrid, Sanchil, I,95. 1491 .

Same. Memoria en defensa de la Junta Central. Malrid, j\$10.

s Martínez Marina, Francisco. Teoria de las Cortes a grandes juntas nacionales de los reinos de Icon y Castilla . Matrid, Fernin Villalnando, $18 r_{3} .2 v$.

Same. Fnsayo histórien-critien sobre la antigua legislación y grineipales cuerpos legales de los reimus de Leon y Castilla . . Madrid, Hija de Joarum (i. Carra, $1808.450 \mathrm{p}$. 
produced two leading works-the theory of the Cortes or the great national congresses of the kingdonns of I,eon and Castile and the historico-critical essay on ancicnt Spanish legislation. I'lorcz Estrada, ${ }^{1}$ whose treatise on political economy experienced four editions to 1835 , discussed in the conrse of a later work (1839) the social question, origin, latitude, and effects of the law or rights of property. There must be cuumerated also the names of Benito Jerónino Feijo, and the Counts of Floridablanca and Cabarrús who were among the great jurists of this period.

The constitutional novement in Spain begins with the convening of the Cortes of Carliz in 1812 and this may be said to constitute the fourth epoch in the listory of the philosophy of law. It extends to the present day. Anong those who represent the first half of the ninetenth century Donoso Cortes, Balmes and, in the second hall, Sanz del Rio liave exerted a lasting influence. Donoso Cortés ${ }^{2}$ represents a very conservative theological school. Ile brought himself into prominence at the age of 27 by a series of lectures on political law delivered in the Ateneo of Madrid. A complete edition of his works was published in 1854 . His essay on catholicism, liberalism and socialism exereised particular inlluenec. Bahnes ${ }^{3}$ was of the theological school, but in truth he was a philosopher. His works include many dealing with general philosoplyy. Ilis politico-legal theories are comparable to those of Donoso Cortés, except that Balnes defends the old form of nonarchy as distinguished from a constitutional

I Florez listrada, Alvaro. Cursu de conomía política. „th ed. Madrid, Miguel de Burgos, $18_{35} .2 \mathrm{v}$.

Same. La cuestion social, origen, latitud, efectos del derecho de propriedad. Madrid, IS39.

"Donoso Cortés, Juan. Obras de . . [ " Lecciones de derecho político pronunciad as en el Atenco de Madrid," vol. I, pp. I I 5-272; Principios constitucionales aplicados al proyecto de ley fundamental, etc. vol. I, 1) 300-347. Ensayo solure el catolicismo, el liberalismo y el socialismo. vol, 4. pl. [-400]. Madrid, Fe jado, $1854 .+\mathrm{V}$.

Aalnes, Jaine. Éscritos politicos de... Madrid, Operarios, 1847 . Sos p..

Sane. Ia Sociedad, revista religiosa, filosófica, política y literaria. 5th eal. Barcelona, barcelonesa, IsSg. 4. v, in 2.

Sime. Fi criterio. Barcelona, Antonio Brusi, I8 46.3841 .

Same. Niscelánea religiosa, politica y literariat. Barcelona, Bareelonesa, 1900. 3i7 1). 
monardy. Anong the writings of merit tonching npon the philosophy of law and jurisprudenee are a one volume collection of "political writings," of which the essay, the "thought of a nation," is of especial value, a two rolune review of society from a religious, philosophical, political and literary viewpoint, and the work "Elcriterio." A volume of selected misedlaneous political and religions articks was published recently (rgog). Sanz del Rio,' a follower of Krause, has enjoyed perhaps the greatest influence anong the liberals. Snch modern leaders as Giner de los Rios, Salmeron and Azcírate are his deciples. Hesides his purely philosophical works, he has published the "Ideal of humanity for life," an adaptation of the book of Krause on ethics, polities and sciology.

The most important and best representative of the Catholic school is Prof. Juan M. Orti y I ara, still active at the age of eighty-nine." IJis "Introduetion to the study of law and principles of natural law" is one of the leading works of Spanish lin. Ite has written sereral essirys and interestiner introduetions to translations of foreign works. His address on "Opposed theories of the purpose and end of the state from the conception of its evolution or creation "before the Acadcmy of Moral and l'oliticit Sciences at tracted much at tention.

Frof. Giner de los Rios, ${ }^{3}$ professor of philosoplyy of law in the University of Madrid and the leading Spanish contemperary anthority on the subject, is a disciple of Kratuse and Sane del Rio. IIe has published a collection of essays or studies on legal and politieal questions in a 879 , sercral notes to Ahrens' juristic encyclopedia and the wotk "The social person" ( I Syg). Two of his inportant contributions to the philosophy of daw

1 Sam del Rio, Julian. Ideal de la linmanidad para la vicla. ad ad. Madrid, I87 . $2 \mathrm{v}$.

2 Orti y Lara, Juan Mamenel. Introdncción al estudio ded dercelos y prin eipes de drerclo matural. Madrid, $13-8$.

Same. 'Teerias opuestas contre si acerea del estado y su fin, segun efue proceden del concepto de lat evolución ódel concepto de lat createini Madrid, Jaime Rates, 1uos. (Vol. VII, [1]. 100-28s of Discursos de recepción de lat academia de eicucials morales y politiens.)

${ }^{3}$ Ciner de los Rios, Iranciseo. Iistudios juridicos y puliticos. Marlrid, V. Suarez, $18 ; 5.34+1$.

Sanne. Ia persma sreial. Estudios y frignentos. . Madrict, $V$ Suarez IS(m). 4.331 , 
have been published with the collaboration of the late Calderón. These are a "Resumen" of philosophy of law 1 (1898) and "prineiples of natural law." 2 The former work, of which only one of two projected volunies has appeared, contains a summary of the principal problems of the philosophy of law, a preliminary article relating to the ordinary understanding of law, and an int roduction dealing with the conception, encycloperlia, sonrees and method of philosophy of law with generat, special and organic parts of this seience. Calderon ${ }^{3}$ hinnself has produced many leading essays and monographs gathered in the volume "Irifles" and others.

The works of the late costa, who died in 1911, make him one of the foremost Spanish jurists. Hfe, too, is a disciple of Krause, alt hough his theorics, ete, indicate the great infuence of the historical school of Sarigny and I'uchta, especially of the former. Costa ${ }^{4}$ has dealt with such interesting topies as "The life of law" (an essay concerning customary law), "Theory of the juridic fact, indiviclual and social," and "The problem of ignorance of law." In addition, he has published a collection of legal and political essays. He has inftuenced more than anyone else the development of the study of the customary law of Spain. Another collection of political and philosophical studies of importance came from the pen of Prof. Azcárate, ${ }^{5}$ the president of the noted Institute of Social

1 Giner de los Rios, Francisco and Calderón, Alfredo. Resumen de filosofia del derecho. Madrid, V. Suarez, isg8. 390 p.

" Giner de los Rios, Francisco and Calderón, Alfredo. Prolegómenos del derecho. I'rincipios de derecho naturil sumariamente expuestos . Madrid, Biblioteca de linstrucción y Recreo (no date). 290 p.

"Cilderón, Alfredo. Nonadas. Jilboa, Inipr. Artística de Miiller y Zavaleta, $1896.322 \mathrm{p}$.

"Cista, Jonquin. La vida del dereclo. $2 d$ ed. Madrid, "Biblioteca Costar," Ior 272 p.

Sime. Teoría del liceho juridien individual y social. Madrid, Rev. de legislación, $\mathrm{I} S 8 \mathrm{o} .37 \% \mathrm{p}$.

Simme. El problema de la ignorancia del dercelio y sus relaciones con el status individual, el reforendum y la costumbre. Madrid, San Francisco de Sales. 1001. 105 1).

Same. Fistudios jurídicos y políticos. Matirid, Rev. de legislación, 1884. $\$ 39 \mathrm{p}$.

5 Azcárate, Gnmersindo de. Estudios tilusóficos y politicos. Madrid, 18,8 .

Same. linsayo de una introducción al estudio de la legislación contparada y programa de esta asignatura . . Madrid, Rev. de legislación, $1874 . \quad 1881 \%$. 
Reforms. Azcirate is of the Krausian school and also a follower of Sinz del Rio. He prepared, in 1874 , an interesting int roduction to the study of comparative legislation, followerl by an ontline of his comse on this subject in the University of Marlud law sefool. Most of his works deal with political connony, companative law and social seience, and have cittsed hinu to be regarded as a leader in these fields.

An important contribution by the late I'rof. Gil $y$ Robles' appeared in 1895 as a prologue to the Spanish translation of Stahl's "History of the philosophy of the law." The author, who is of the Catholic school, is onc of the most important of modern conservative theorists. His treatise on politieal law according to the Christian principles of philosophy and law also warrants mention. His monographs on "absolut ism and democracy" and the "legal methodology" show evidences of the inlluence of Krause.

I'rof. Dorado Montero ${ }^{2}$ is the nost important spanish atthor of a philosophy of law from a positivist point of vicw. liowever, in his pendil studies, for which le is best known, he shows the intluence of Kratuse. Ilis leading cont ributions to the litcrature of jurisprudence and philosophy of law are the "Bases for a new penal law," the "Social value of laws and authorities" and the "Law and its priests," a substantial book on the most interesting problems of the philosophy of law. Rivera Pastor, who show's inclinations toward Stammler, published, comparatively recently (1910), an interesting disctission of the doctrines of law and of the state and in 1913 a monograph on the "logic of liberty", published in volume

${ }^{1}$ Gil y Robles, Enrique. Tratados de derecho politico según los principios de la filosofia y el dereclo cristianos. . Salantanca, Silnanticuse, $1889.2 \mathrm{v}$.

Sinne. Fil absolutisno y la denocracia. Salananca, J. Nuñez I zquierdo, 1 Sor. $61 \mathrm{p}$.

Sante. linsayo de nuctodologia jurielica. . Salamanca, Salmanticense, $1893.223 \mathrm{p}$.

${ }^{2}$ Dorado Montero, Pedro. Bases para nu nuevo deredo penal. Batrelunk, M. Soler [1902]. 200 p.

Same. Valor sudal de leyes y atuturidades.. Barcelonal, M. Sieler [1003]. 201 $\mathrm{p}$.

Same. El derecho y sus sacerdotes. Madrid, Rev. de legisheion, Igoy. 592 ).

${ }^{3}$ Rivera I'alstor, I'rancisco. Ias doctrinas del derecho y del estado. Madrid, V. Suarez, rolo. 2 I 1 p. 
$\mathrm{X}$ (1913), pages fo1-448, of the Anales de la junta para amplicación di cstudios. Rios Urruti, also a disciple of Stanmler, has contributed to the new neokantian philosophy of law his monograph "The problem of the eontinnity in polities" (volume II, 191 I, PP. I-24, 152-162, La lectura) and some others, as well as his introduction to the translation of Jellinek's "General theory" of the state."

There are many others who have enriehed Spain's legal literature in this field. Among these, Concepcion Arenal occupies a prominent place. She was an extraordinary penologist and noralist, and probably the foremost woman publieist of the world in this field. The jurists and publieists, Santanaría de Paredes, Alas, Posada and Novarro Flores can not be omitted in a roll of Spanish writers in the general branches of jurisprudenee and philosophy of law.

A notable achierement in Spain for the advaneenent of the science of jurisprudenee and comparative law was the establishment in Madrid of the Instituto Ibcro-Americano de Dercho Positio Comparado in December, 1908. The founders eomprise numy of the leading publicists and jurists of Spain. The purpose of the Institute is to promote and improve juridieal and soeial relations between Spain and the Spanish-speaking nations of America, although all the American and European nations are invited to take part in its program.

\section{LEGAI, IIISTORY}

The history of Spanish law assumes far more than a loeal iuportance. In the early Spanish codes and compilations may be traced sone of the most lasting institutions of Roman law, and they were the medium throngh whieh Spain earried her law into the new world. The adminst ration of the Philippines and other former Spanish possessions by the United States has brought us into intinate contaet with nuch of the law of these early compilations, and revived an interest in their study.

1t is impossible to trace the law and legal institutions of Spain to the time anterior to all foreign contact. The Ilserlints and the Celts are sometimes considered indigenous inlabitants of Spain, lut, acording to better opinion, they were invaders. He do not know whether or not there 
existed among them ntilizable texts of law. The Plusencian and Greek coldnizations, which followed the oecupation of the Herians and celts, have likewise left us no texts. J. Costa ${ }^{1}$ has in several works published the resules of his researches into this period of Spanish legat history, and "has allempted to differentiate the sources of the customs or laws of the first inhabitants of Spain known to history." Ilis Plan de historia offers especially a complete guide to the institutions of the Roman and civil taw introlneed into the Peninsula during the period of Roman rule (200 B. C. to foo A. D.).

The Visigoths, a branch of the great nation of the Goths, made the concluest of spanin in the fifth century and created a new Gernuanic law by the sicle of the Roman law. This Ronan law the conquerors recognized as freculiar for SpanishRomans and they cotified it during the reign of Alaric. This compilation is known in history nuter the name of the Breviary or cole of Alaric $(506)$ and, anong scholars of the present day, as the Lex romana zisigothorum. it is interesting to note that no Spanish edition of this cocke exists. The cdition generally recommended is the recent German translation made by I'rof. Max Conrat (Cohn)" from Hacnel's ${ }^{3}$ Latin colition, which furnishes a systematic classification by subject matter. The Gernan intluence on Spanish law is admirably described in a monograph by Hinojosa. ${ }^{4}$

The customary laws of the Visigoths were codified hy their King Euric $(467-485)$ who is accorded the honor of having been the compiler of the earliest code of the laws of Spain. It

I Plan de historia. Insayo de un plan de historiablel dereclo espanum en la antiguedad. By Joaruin Costa. (Revista general de legislacion y jurisprudencia, vol. 68,1886 , pP. $527-557 ;$ vol. $70,188_{7}$, il?.

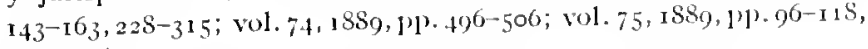
$44(-453)$.

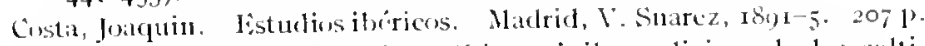

Costa, Joaquin. Organización politica, civil y religiose de les celei. bericos. Madrid, Ml. Murillo, is7?- is l'.

2 Conrat (Colnu), Max. Breviariun Alariciannm; rönisebes recht in fränkischen reich in systematischer darstellung . . Leiprig, J. C. Hinrichs, 1903 . Sis 1 .

"Hancl, Gustavos. Lex romana visignthornm, Lipsia, H. G. T(1)bseri, $18+4 \% .408$ p.

"Hinojosa, Vidnardo le. Das germaniscle clement im spaniselen rechte. Weimar, Hermann löhlams Nachf. I9ro. 79 p 
is not certain that we possess to-day the text of this code of Euric.

The two bodies of Spanish population, I atin and Teutonic, continued to live nudler this dotible system of law until the reign of Kindasinth $\left(6 f_{2}-65.3\right)$. He reduced the dival or racial legislation to one common cole based on all the prior codles and statutes. Ilis son and succeeding kings modified and added to this code, which came to be known under the name "Fuero juzgo." By this legislation the influence of the Germanic spirit became fixed as one of the universal factors in Spanish law and temporarily, at least, destroyed the work of Romanization. In an old volume ( 1819$)$ of the Edinburgh Review (rol. 31, pp. 94-132) there is a short description in English of the Gothic laws, espccially the criminal trials, written in an interesting but "story-like" style.

The "Fuero juzgo" is known under the following names: "Codex lequm," "Liber gothorum," "Lex wisigothorum," "Liber judicum," and "Forum judicum"; the latter title was changed at the beginning of the thirteenth century into "Fucro juzgo" by which it is now known. "Fuero juzgo" is really a contraction of "Fucro de los juccs," or the law of the judges. It arose, as has been shown, from the gradual fusion or analgamation of the Roman and Gothic law. The doctrines of civil law which are at greatest variance from the strict Roman law are those relating to marriage, conjugal property, family relationship, some principles of property, and much of the law of persons. On the other hand, the preponderance of the Roman law is seen in nuatters of inheritance, especially testamentary, and of preseription and contracts; though, as regards the form of these last, a broad and liberal principle prevails very different from the rigid classification of the Roman law.

In form the "Fucro juzgo" las little pretension to method and logical arrangement. It contains a preliminary title and 12 books which contain 54 titles, subdivided into some 578 laws, parts of which are attributed to different kings. The preliminary title treats of the election and duties of monarehs and the duties of their subjects, and includes the public law of the Visigothic monarely formed in the Fonth Council of Toledo. Although imperfect, this title includes in reality one of the earliest written constitutions of Iurope in which are 
recognized principles as liberal as those known to any modern nonarchical constitution. Wit hin the i 2 books are contained laws for the making of laws, procedure, fanily relations, administration of estates, contrats, mortgages, crimes, torts, real property, maritime commeree and variots questions. An anly edition of this colle las been translated into linglish by S. l'. Scott ${ }^{1}$ under the anspies of the Comparative law Bureat of the Ancrican Bar Asseciation. The translation and the skill of the editor are severely crilicised by some of the leading atthorities in this fichl. Judge Lobingier presents a good smumary of the contents of the Futro juzyo and a deseription of its sources in the lllinois I ait Review volume 8 (191,3) pages j-18.

For historical purposes and for accuracy the edition of the "Fuer juzgo" by Zemmer," published tunder the seetion of "Leges" in the "Monumenta germania historica," is probably the best. The Royal Academy ${ }^{3}$ of Spain prodnced in is I 5 an clition which, as a literary and philosophical work, is desening of much commendation. It can not be relied on for practical reference, however. It embodies a learned dissertation on the law of the Visigoths and a preliminary title, "De electione principum", not to be found in the foreign editions.

IFollowing the Arabic conguest of the Visigoths in the eighth century, a vast and varying body of law arose which added to the complexities of Spanish law. Altamira ${ }^{4}$ in his recent $(1914)$ work on questions of the history of law, discusses the Moslem rule in its influence upon Spanish law and presents a compact résume of the period. For a thorough study of the influence of the Moslen rule a brochure of Ureña may be recomnended. 'This article was reprinted in his history

${ }^{1}$ Scott, S. P. The visiguthic code. Boston, Boston Book Co., rgto. $420 \mathrm{p}$.

a Monumenta germaniae historiea. Leges, Sectio 1, tomus I, l,eges visigothorum edidit Karolus 7enmer. Hannoverac, Impensis Bibliopolii Hahniani, I902. 1)p. 3.3-456.

${ }^{3}$ Fuero juzgoen latin y castellano, cote jado con los mas antiguos y preeiosos codices por la Real Acadentia Fispañula. Madrid, lbarra, 1815. $2.3 \mathrm{IP}$.

- Altamira y Crenea, Rafael. Cuestiones del historia de derceluy y legislación comparada. Madrid, Sucesores de Hernindez, I9I. $402 \mathrm{P}$.

"Ureña y Smenjaud, Rafael de. La intluencia semita en el derecho medioval de lispaña. Madrid, Rev. de legislacivin, asgs. $4+\mathrm{p}$. 
of Spanish legal literature, which is a summary of the lectures on the history of Spanislt legal literature delivered by Ureña at the University of Madrid, 1907-r9o8. The lectures include a study of the legal literature of prinitive, Roman, Cothic and Arabie Spain. In Martínez Marina's 2 historical work there nay be found an acconnt of the institutions of public and private law in this period.

The rulers of Castile, whose power becanne predominant among the small states that had been established, promulgated several general codes and compilations of laws. Among these the Futo virjo (1212) was more particularly designed to define and sanction the prerogatives of the nobility. An edition of this compilation was published by Asso and Man$n 1^{3}$ in $177 \mathrm{I}$ in their collection which includes, in addition, El ordenamiento de leyes de Acali, with notes and reports of the Cortes convened in the reigns of Sancho $1 \mathrm{~V}$ and Ferdinand 1V. 1t is also fully treater of in the works of Manrichalar and Manrique in their history of Spanish legislation (infra, p. 38$)$.

The Fuero aicjo was followed by the important code which Alfonso $X$ issued in 1254 , known commonly as the Fuero Real. This was an example of the unitive tendency manifested at different tines. The code, which became a model, was based on all the fueros and especially the Fucro juzgo, with modifieations, embracing, in four books, political, procedural, civil, criminal and commercial law. The original text was modified by Alfonso $\mathrm{X}$ himself in $127 \mathrm{~S}-1279$ and by the Cortes of Valladolid in 1293 .

There are several editions of this cole, although none of any critical valte. The leading and most reliable was edited with a commentary in Latin by Díaz de Montalvo in 1500 , and another by the Acadeny of History of Madrid ${ }^{4}$ in ${ }^{8} 3_{3} 6$,

${ }^{1}$ Ureña y Smenjaud, Rafael de. Historia de la literatura jurídica espanola. Intento de una historia de las ideas juridicas en Fispaña. ad ed. Madrid, I. Moreno, 1906. $2 \mathrm{v}$.

${ }^{2}$ Infra, 1). 37.

3 Asso y del Ria, Ignacio Jordan de, and Mannel y Rodriguez, Miguel de. Iil fuero vicjo de Castilla . . y con otros mss . . Con notas históricas, y legales. Madrid, de Camara de S. M., I771. 56,143 P.

${ }^{4}$ Opúseulos legales de Rey Don Alfonsocl Sabio. Publicados y cotejados con varios codices antiquos por la Real Aeademia de la Historia. Mudrid, Real, $18_{3} 6,2 \mathrm{v}$. 
published in their two volume colketion of eodes. This collection in volume one includes "El Especulo, or "Mirror of all the laws", and in volume two, the Fucro heal and some of her leyes of lesser importance. "There is also an eflition publisled in the collection of the publishing homse of La P'ublicitut!' This is a full and complete collection of ancient codes including the Furo jusgo, the Fucro viejo, the Leyes del evtilo, the Furro real, the Ordenamiento de thali, the Sicte partides, Espéculo, Ordenanad de Castilla, Nueza recopilarion, Nozisima recopilacion, Autos acordalos, and the Ordenanza de Bilbao. The text of Diaz de Montalvo ${ }^{2}$ was republished in $1-8$ i witl references to similar passages in the Particlas. The Latin comment to his edition of 1500 is appended.

Alfonso $\mathbb{X}$ promulgated other groups of statules after the Fucro real, e. g. the Leyes nueves, which dealt with only a few topies, such as the relations between Christians and Jews in the matter of loans, civil procedure and inheritance. There was also prepared in 1258 , under the command of Alfonso $\mathrm{X}$ or on lis private initiative a compilation of a legal character analogots to the Siptenario conceived of and partially prepared by Fernando III, which compilation directly preceded the Partidas and followed the Especulo. The title Espéculo (or Espejo) or "Nlirror of all the laws" was a name mutuch used at the time throughout Europe to designate doctrinal treatises. The Especulo was utilized by lawyers of the tine as a text and reference book. The Madrid Acadeny of History issued an edition of the Especulo in 1836 .

The great legal compilation, the Código de las . Siete Partidas (or the Code of Seven Parts) was begun in $125^{6}$ and was completed abont 3265 . Its preponderant elements were the canon law and Roman law. In fact the general character of the Partidus is that of an encyclopedia or systematic compendiun of these two legal systems. The redaction of the Partidas was the work of several jurists, whose names are not cited in the text, and was done mider the supervision of Alfonso, who was hinself an author of zeal. This work also

1 Los códigos españoles, concordados y anotados. Madrid, "La Publicidad," I $S_{47}-\mathrm{I} S_{5} \mathrm{I}$. I $2 \mathrm{v}$.

2Diaz de Montalvo, Alonso. Jil Fuero real de Fispaña, por Don Alfonso IX: glosarlo ad icionado, $y^{*}$ concordaro con las Sicte Partidas $y$ Leyes del Reino. Madrid, Pantaleón A $\angle n i r, 1,81.2 \mathrm{v}$. 
bears the name of Libro de las leyes. The book is divided into seven general headings, as follows: ist, The catholic faith; 2nd, 'mperors, kings; 3 rd, justice; 4th, marriage; 5 th, contracts; 6hl, wills; 7 th, criminal law. S. P. Scott of the Comparative Law Bureau has translated this code into English and the Burean announees that it will soon be published $(1914)$. The best edition for practical purposes and the one used by the courts is that of Lopez, ${ }^{1}$ published under royal anthority in the years $1829^{-1} S_{31}$. 'The edition of 1807 , by the Spanish Academy of History ${ }^{2}$, is inaccurate for practical purposes, and in a decision of the Supreme Court of March 27 , 1860 , it was decided that in case of contlict between this edition and that of Lopez, the latter should prevail. A reprint of this work was published in Paris about forty years later. Judge Lobingier recently published in the Annual Bulletin of Comparative Law Bureau, volume 6 (19r3), pages 33-50, a brief analysis of this great Spanish law bonk of the Middle Ages, and in an article in the California Law Review [vol. 1 (1913) pp. $487-498$ ] the sume aut hor discussed it anch its predecessors.

The Partidas dial not become the law of the land until nearly a century after its first appearance. But as a direct result of it and of the renewed prestige of Roman law the struggle between Romanism and the native law arose and continted for several centuries. The Ordenamiento de Alcalá was published in 1348 by Alfonso XI. It presents, in the order of their authority, the different sources of law, such as the statutes enacted in the Cortes, the fucros ete. The Partidus was made a supplementary law and was given royal sarsetion. No edition of the Ordenamiento can be recommended. The lext as it appears in the collection of Asso and Manuel (supra, p. 30) is equal to any, but it is admiltedly defective.

The various coles, fueros, and compilations existing at this period of the law caused a great complexity of the positive law, and the resulting conlusion and donbt continually led to attempts to deternine what was obligatory in any case.

${ }^{1}$ Iópez, Gregoria. Las sicte partidas. . glosadas par . . Madrid, leon Anlarita, $1839-18_{3} \mathrm{I} .4 \mathrm{~V}$.

2 Fas sicte partidas. . cotejadis con varius codices antiguos . . Par la Real Aesdemia de la Ilistoria. Madrid, Impr. Real, 1807. $3 \mathrm{v}$.

Sume. Nueva ed. Paris, Castellana, 1846. $2 \mathrm{~V}$. 
The changes in the political order cluring the reign of lierdinand and Isabella produced a great development of legislation. These rulers attempted to introduce sone order into the system of legislation by lle publication of the Ordenamiento real (1490) and the Leyes de Toro (1502). Instead of simplifieation they only tended to increase the confusion. The first Ordenamiento was popularly kuown as the Ordenamiento det Doctor Montalio, because it was edited by a distinguished jurist, Alfonso Díaz de Montalvo, together with Galindez de Carvajol, under a commission from Queen Isabella. It was a collection of laws, but did not attain legal authority. The last edition of this corle was issued in the collection of the publishing louse of La I'ublicidal in is72. The Leyer de Toro or the "Laws of Toro" was in no sense a code, but it had as its object to explain and supply defeets in existing legislation. It inclined usually to the Roman and canon law in the struggle between Ronan law and native law. A commentary on this statute by Llamas ${ }^{1}$ appeared in a second edition in 1852 . Pacheco's 2 connentary of this law may also be noted.

The spread of the Justinian and eanon laws in the lesser kingdonns of the Peninsula, e. g. Aragon, Catalonia, Narvarre, Basque provinces, and Guipuzcoa, marks an important erent in the history of the law. These kingdoms, now provinces, began to secure special rights and powers, many of which are yet retained. These form a body of law entitled "dercho foral" (infra, p. 4.2), which often discloses conflicts with, and raises obstacles to, attempted current legislation. The abundance of legislation during the period of the absolute monarchy, along with the tendency toward codification in systematic form, caused repeated petitions in Castile for new collections, and in the other hingdoms for the continuation of those already instituted in the preceding period. In the reign of Philip II the Nucia recopilacion (1567), intended as a general code, was finally promulgated, and furmishes some

1 I lamas $y$ Molina, Sanchu de. Leyes de Toro. Conentario, criticojurídico-literal a las leyes de Toro. al col Madrid, Sinchez, I852. 600 \%.

2 Pacheco, José F. Conentarios de las teyes de Toro. Madrid, Gello, $1862-1876.2 \mathrm{v}$

77:31-15-2: 
guide to the general law of the Kingdom, although it is far from satisfactory. It tumed out to be 10 more than an elaboration of Montalvo's compilation in its identical elements.

The earlier codes retained in the main their authority. Many statutes were enacted and pragnaties and orders were issued by the House of Austria; the greatest in number and importance being those relative to the colonies (Leyes de Indias, 1680). The attempts and st ruggles in Castile for an anthentic compilation were reenacted in Aragon, Catalonia, Valencia, and other kingdoms and provinces. This period, known as the "Hapsburg period," was prolific in legal literat ure.

The house of Bourbon abrogated but little of the Castilian law. No new codes were introduced and only a few institutions of the existing codes were changed. The 1700's constituted a period of great reforms in the social and political life of Spain. In successive and enlarged or revised editions of the Nucva recopilacion (between 1567 and 1777 ) there were brought together new royal orders and the important deerees or decisions of the Council of Castile (Consejo de Castilla). The Bourbons ended the work of political mification begun by the Austrian house by annulling many of the special laws enjoyed by Catalonia, Majorea, Valencia and Aragon-in each state those regarding the public law (with slight exceptions), and in Valeneia those regarding the civil law as well. The colonial statutes relating to industry and public instruction were modernized as were also, in part, those which defined the relations of church and state. The legislative diversity, both as between the different ancient kingdoms of the Peninsula and also within Castile itself, continued particularly in the civil law. The jurists of the eighteenth and early nineteenth centuries proved unequal to the task of fusing all these elements into one code or even into two, one of public and one of private law.

The compilation of laws known as the Novisima rccopilacion (1805) is a chaos of general provisions, applying particularly to Castile, but also affecting the whole of Spain. Within 12 books are nuingled provisions governing the Cortes, fucros, kings and Council of Castile from the medieval period down to the date of publication. The "Novisima" did not satisfy the necessity which it assumed to nuet, that is, of concen- 
trating the legislative law. There is a six volume edition of the Noaisima recopilacion ', published in Madrid in is $\$ 29$.

The ancicut coles of Spain were reprinted in full, in a larese volune, in 1885 , by Hartinez Aleubilla. ${ }^{2}$ A glossary of ancient legal terms is given. It appears to be the most contpact and practical collection.

It is a remarkable feature of the legislat ion of Spanil that at no tine was any attempt made: to prommlgate a new code which would abrogate the old one. Hence, lo determine the law on any given sub ject all the different corles nust be examined, with the linitation that the latest in point of tine is first in authority. The Fucro aicjo has been so modified and changed by subsequent enactnents that it can no longer be consulted for any useful purpose. All that remains useful of the Ordenamiento real and the Leyes de Toro has been incorporated into the Nuevand, finally, into the Noz'sime recopilacion. The Norisima recopilacion is the latest as well as the highest anthority, but when it is silent some diversity of opinion exist as to which of the remaining codes ought to prevail. Sonte anthors give the preference to the Partidus, others to the Fuero juzqo, or to the Furo real-the getweral legislation of Spain being found in these four codes or connpilations.

In the last century of reform and innovation in Spain, mmerous constitutions were adopted and repealed until the adoption of the Constitution of 1876 , now in force. Civil, comnercial, crininal and military law have all been enbodied in separate codes which are complete and are applicable thronghout the entire kingdon. A judiciary act and codes of civil and eriminal procedure have also been enacted. The most inportant step in recent Spanish history was the appointnent in 1910 of a commission to revise and recodify the civil, penal and procedural codes and the judiciary laws. This commission is composed of nine members under the ox officio presidency of the Minister of Grace and Justice and has

1 Novisima recopilación de las leyes de Fsaña, dividida cil 12 libros. Madrid, Jutian Viana Razula, $1805-1820.6 \mathrm{v}$.

"Martinez Aleubilla, Marcelo. Cóligos antiguos de España . . desde el Fuero juzgo liasta la Novísina recopilación. Madrid, Administración, $1885.2,050 \mathrm{p}$. 
been commanded to proceed at once with the task assigned. Nothing of importance, however, has resulted publicly from the four years' existence of this body.

In suggesting and recommending works on legal history, it must be confessed that there is a great inadequacy of historical accounts. Those we have are fragmentary, and are usually either histories of the development of certain institutions followed from text to text through the so-called codes with indication of the changes that these record, or are histories of brief periods of Spanish law.

In I9o8 Rafael Altamira, one of the two or three foremost legal historians of Spain, presented an account of the actual state or condition of the works on Spanish legal history to the International Congress of Historical Science. The paper was reprinted in a French magazine, the Bulletin hispanique, volume in (1909), pages 173-199. The writer criticizes the existing works on legal history, and in addition discusses the teaching of the subject. For English readers by far the best and most concise work on Spanish legal history is the chapter (pages 577-702) on Spain in the first volume of the Continental I.egal History Series.' This contribution was made by Rafael Altamira. Within the brief space of 125 pages are covered the origin, early growth and development of the various influences on the law down through the nineteenth century, with its great legal reforms.

In 1852 the German publicist Brauchitsch wrote a short history of Spanish law. ${ }^{2}$

There are several treatises in English on the civil law of Spain which give by way of introduction brief sketches of the legal history. Among these may be mentioned Walton's ${ }^{3}$ "Civil law in Spain and Spanish America." There is also a

1 The continental legal history series. Vol. I, Historical survey of the sources, literature and general development of continental law. By R. Altamira, H. Brissaud, H. Brunner, C. Calisse, E. Hertzberg, F. Huber, M. Planiol, R. Stintzing, J. A. Van Hamel, and others. Translated by Rapelje Howell, Francis S. Philbrick, and John H. Wigmore. Boston, Little, Brown and Co., 19r2. 754 p.

${ }^{2}$ Bratchitscl, Heinrich von. Geschichte des spanischen rechts. Berlin, Allgemeine dentsche verlagsanstalt, $1852.203 \mathrm{p}$.

${ }^{3}$ Walton, Clifford Stevens. The eivil law in Spain and SpanishAmerica. Washington, D. C., Lowdermilk and Co., I900. 672 p. 
sonnewhat older work by Schmiclt ${ }^{1}$ of the Louisiana bar which contains an historical introduction to the law and the various codes.

Among the most creditable efforts in legal history is the treatise of Sempere, ${ }^{2}$ a writer of authority. The first edition, in 1822 , was published under sanction of the Government. This work traces the Spanish law from the earliest sourecs through the Nozisima recopilacion. The third edition continues the history down to the middle of the nineteenth century. The most reputable general history of law was begun by Hinojosa, ${ }^{3}$ the learling atthority in the field, but only one volume has been published. Nevertheless, this is an important contribution and covers the period through the Visigothic domination. Hinojosa ${ }^{4}$ has also published a onevolume book of studies on the history of Spanish law, which contains among other matters a discussion of the origin of the municipal system in Leon and Castite.

Reference may be made to the historical work of Chapado Garcia ${ }^{5}$, which professes to give an account of the "preparation" to the "consumnuation" of Spanish law, but in fact is of little value. The crities are extrenely severe, charging even plagiarism. Altamira "in 1903 published a short essay" on "preliminary questions" of Spanish legal history.

There are numerous historical accounts of Spanish legislation. An essay by Martinez Marina ${ }^{7}$ on the ancient legislation and the principal bodies of laws of Leon and Castile, and

${ }^{1}$ Sehmidt, Gustavus. The civil law of Spain and Mexico. New Orleans, La., Tliomas Rea, $1851.37^{6} \mathrm{p}$.

${ }^{2}$ Sempere, Juan. Historia del derecho español. Continuada liasta nuestros días. 3d, ed. Madrid, Rodríguez de Revera, is 46.57 I $p$.

${ }^{3}$ Hinojosa, Eduardo de. Historia general del derecho español. Madrid, los Huérfanos, $1887.37^{8} \mathrm{p}$.

- Hinojosa, Eiduardo de. Estudios sobre la historia de derecho españul Madrid, los Huérfanos, 1003. 248 p.

${ }^{5}$ Chapado Gareía, Eusebie M. Historia general de derecho espanol. Valladolid, Jorge Montero, 1000. $971 \mathrm{p}$.

- Altamira y Crevea, Rafacl. Historia de derecho español. Cuestiones preliminares. Madrid, V. Suárez, 1903. $220 \mathrm{p}$.

' Martinez Marina, Franciseo. Ensayo histórico-crítico sobre la legislaeion y prineipales enerpos legales de los reinos de leon y Castilla, especialmente sobre el codigo de las siete partidas. $3 \mathrm{~d}$. erl. Madricl, Sociedad, I $845.574 \mathrm{p}$. 
chielly of the Sicte partidas, may especially be noted. An article by Torres y Aguilar, a former professor of the University of Mladrid, in volnme 6 of the Journal du troit international prizé ( I 899 ), pages $27-40$, discusses briefly the different ancient codes and their influence on nodern Spanish law, especially the conflict of laws. The most extensive history of Spanisl legislation is that of Marichalar $y$ Manrique. ${ }^{1}$ It was prepared with special reference to the civil and private law. The first rolune, after an historical introduction, begins with the Roman period. In the other volumes the legislation through the reign of Isabel 11 is discussed. The following states and provinces of the Peninsula still retaining the foral or local law are individually corered-Navarre, Aragon, Catalonia, Valencia, 1'rovinces V'ascongados, Vizcaya, Guipnzcoa, and Alava-while $i n$ addition colonial Jegislation is discussed. A few other works on Spanish legal history which might have been mentioned have been intentionally omitted because of their inaccuracy or unreliability.

\section{CIVIL CODE}

\section{IISTORI}

The Spanish civil code was pronnlgated in the Peninsula by the royal decree of July 24,1889 , and was extended to the colonies on July 31, 1889. It has not proven entirely satisfactory. This is dne perhaps to the peculiar conditions created by the concurrent existence of the foral or local haw enjoyed by several provinces and the adoption of sone I rench institutions foreign to Spain. It is interesting to note that two eninent foreigners, A. Levé, who translated the code (injra, p. 4\$) and Judge Lobingier ("A Spanish object-lesson in code-1naking") in volnme 16 of the Yale Law Jonnal, pages $f 11-f 16$, complinent it highly, whereas severe criticism is levelled against it by the two leading contemporary anthorities in Spain, Sínchez Román and Clenente de Diego, in their treatises.

Iegislative his- The history of the code begins with article 259 of the Constitution of Carliz which lays down at once the principles of

1 Marichalar, Analio, and Manrique, Cayetano. História de la legislacion y recitaciones del dercelo civil de España. Madrid, Nacional, $1501-1572.9 \mathrm{r}$. 
mifteation and codification-" A single civil code shatl he in force in all the dominions of the Spanish nonarcly." "The Cortes of Cadiz approved in 1811 the resolution of the biputado (Deputy) lispiga to codify the most important branches of the Spanish law. In furtherance of this project a committce of distinguislied men was appointed in 1813 to accomplish the work, but the violent reaction of 1814 , and the return of fierdinand VII to the Spanish throne, teminited these preparations. The Cortes during the second constitutional régine in 1821 made another attempt to accomplish codifieation but, owing to the reaction in $18_{2} 3$, it likewise failed.

Private interest kept the enterprise alive, notwithstanding the opposition in official circles, and P'ablo Gorosacal became the first to publish a project. Another was later formulited by Manuel Matia Cambronero, which was completed by other jurists in 1836 and officially presented to the Corts in 1839 , but no action was taken upon it by the legislative power.

In $18_{43}$ by royal decree a code commission, composed of $2+t$ eminent men, was established. The work done by this Commission $\left(18+3^{-18}+6\right)$ was the first officially accomplished toward a civil code (namely, books 1 and 2 , and part of look 3). Subsequently a committee of six succeeded to the workand, in 1851 , laid before the government the draft of a contplete code, chiefly based upon the Castilian civil law, with the addition of a number of prineiples taken from the regional laws and others taken from foreign systems, especially from the French. With respect to this draft, attention may be called to the contemporary work of García Goyena, ${ }^{1}$ who was the vice president of the General Code Commission and president of the section on the ciril code, as it contains a full discussion of the draft code, with an individual treatment of each article.

The committee fixed seven general "bases" for the codifieation, which was afterwards divided into sections. This project was published, from time to time, to facilitate the examination, study and criticism of the codification and to induce the different tribumals, anthorities, societies of liawyers, miversities, and persons interested to make sngyestions

${ }^{2}$ Garcia Goyena, lilorencio. Concordancias, motivos y comentarios del código civil español. Madrid, la Sociedad Tipogrifico-Fiditurial, 1852 . $+v$. 
and recommendations. The clifficulties and prejudices encountered were severe and great, as each section of the Peninsula was nnwilling to give up its own legislation. This marks the close of the first epoch in history of the civil code in which the "foral" or local laws were disregarded.

The inanguration of the attempt to harmonize may, be called the second historical epoch of the code. After the rejection of the draft above nuentioned the ideal reappeared in $18 S 0$ with the definite ain of fusing the Castilian civil law with that of the other regions of the Peninstula. To this end there were added to the corke commission members representing Aragon, Catalonia, Narjorea, Navarre, Biscay, and Galicia. Nevertheless the draft of a uniform code (or at least one general for the l'eninsula) came to nothing. The foral territories clearly manifested their intention to conserve intact their own law withont fusion with the Castilian; and, indeed, even to exclude its influence altogether.

It appears that the public authorities were doubtful about the proceedings to be followed in reference to the formation of a code. Therefore, in 188 , the Minister of Grace and Justice, Alonso Martinez, presented to the Cortes first a statute embodying the principles of a code ("Ley de bases") and afterwards the partial text of one.

His labor was rendered fruitless, however, through political changes. Several years later, in 1885, another Minister of Grace and Justice, Francisco Silvela, presented to the Cortes a draft of new "bases" upon which to form a civil code, which was enacted into law May 11, 1888. It is wortly of notice that so much importance was given to the enterprise by the general public that the Royal Acadeny of Jurisprudence and Jegislation convened a judicial congress in which the most important matters of the Spanish civil law were discussed, and certain reconmendations made.

$\mathrm{By}$ the statute of 1881 introduced by the Ninister of Grace and Justice, the govermment was anthorized to publish a code which was to be prepared by the section on civil law of the General Code Commission, and to comprise the Castilian law alone. As regards the "provinces and territories in which there exists a foral law," it was declared that this should be respected "for the tine being, in all its integrity, without alteration of their present legal systen by the publication of 
the code, " and that the code in those provinces should be merely "an anthority stpplementary to gaps that may exist in their special law." The code was accordingly published by royal decree of October 6,1885 , to go into effect sixty days after the Cort's hatd approved it. A royal order wis issued lebruary 11, 1859, decharing the code in force May 1, 1889 . Some serious defects were observed and a revision ordered. The work was done practically by one man, Azcárate, and the revised edition was ready in two nonths. This code has been in force since July $24, \mathbf{1} 859$. It is excecdingly important to notice the fact that the first edition was only in effect from Nay 1 to July 24,1889 . The code was extended to Cuba, the Philippine Islands, and Porto Rico on July 31, 1899. In 1910 a commission composed of three jurists and the President of the Supreme Court (Sala de lo ciril) was appointed to revise the civil code but to date nothing has publicly appeared from their work.

In Vohnme I of his "Estudios de lerecho civil," Sánchez Román ${ }^{1}$ gives an historical account of Spanish legislation with a complete and detailed recital of the preparation and legislative history of the civil code. These "Lishudios" will be discussed more at length under the general literature of civil law. The public debates ${ }^{2}$ in the sonulo when the bill was under discussion, particularly those of Azcárate, afford interesting reading, as do the articles published in this connection in the press, as, e. g. the anonymons ones that appeared in the newspaper, La Justicia. Altamira in his article on Spain in the first volnme of the Continental Legal History Series (supra, 1. 36) presents a terse description of the redaction of the eivil code.

The code of 1989 does not satisfy the aspirations for codification, botll because of the many gaps which it left and becanse it left untouched not a few prior laws such as the statutes of civil registry, lypothecary law, waters, mines, lunting and fisheries, etc. The question of the relation of

1 Sanchez Román, Ficlipe. Fsturlios de derechu civil chistoria general de la legislacion espanola. 2rl col. Madrid, Sucesures de Rivadeneyra. I $889-$ I9 I $10 \mathrm{v}$.

${ }^{2}$ Discusión parlamentaria del código civil . . en el Senado durante .. i 888 a ı889. Madrid, Góngora, ı8go. 832 p. 
the non-Castilian legislations (derceho foral) and the eustomary law to the civil code forms at times a perplexing problen.

FORAL SXSTEMS (Derecho Foral) AND THE CUSTOMARY LAW

As regards the non-Castilian or foral systems the code is as a rule only supplementary, though there are a few general provisions that are obligatory on these territories. Walton at pages 112 to 15 of the Int roduction to his "Civil law in Spain and Spanish-America" (supra, p. 36) summarizes the provincial or loeal laws not abrogated by the eiril code, and their order of preference. In article 6 of the "Ley de bases," the formulation of appendices of "foral institutions which it is desirable to conserve" was recommended, but nothing has been done oflicially despite the fact that its preparation was commanded by artiele 7 of the same statute. That of Aragon is already in writing but awaits revision, and of course las not been prominlgated.

The foral law of Aragotn may be fond in the extensive works of Savall ${ }^{1}$ and larral. ${ }^{2}$ The former work is old (1866) but still enjoys reegnition. The shorter disenssions of Franeo $y$ López, ${ }^{3}$ to which sone additions lave lately been made, the work of Blas, and Costa's "Civil liberty" 5 are valuable contributions and earry some anthority.

The appendix of Catalonia, prepared by 'Trias, following the deliberations and labors of the Academia de derecho of Barcelona, has been presented to the government, but likewise has not been protnulgated. 'Trias "has published sone of the results of his investigation in brief form. For researehes into

I Savall y Dronda, Pasenal and Penen y Debesa, Santiago. Fueros, observancias $y$ actos de Corte del Reino de Aragón. Zaragoza, I'ranciseo Castro $y$ Bosque, 1 S60. $2 \mathrm{v}$.

"Parral y Cristobal, Luis. Aragón y sus fucros. Zaragoza, Mariano Salas, Ino\%. $2 \mathrm{r}$.

${ }^{3}$ Franco y Lojez, Luis and Guillen y Carabantes, Felipe. Memoria sobre las instituciones que deben continuar subsistentes del dereeho eivil aragunés $y$ reformas $y$ adiciones que en ellas es conveniente establecer. Zaragoza, del Hospicio, 1886 . I $v$.

* Blas y Melendo, Andrés. Dercelo civil aragonés. zd cd. Zaragoza, Cecilin Gisea, 1898.514 p.

5 Costá, Joaquin. Lat libertid civil y el congreso de jurisconsultos aragoneses. Madrid, Rev. de legislación, $1883.536 \mathrm{p}$.

"Triss, Juan de Dios. Conferencias de derecho civil de Cátalnña. Barcelona, la J Iormiga de Orn, ISgg. I9I j. 
the Catalan law the best works are Durán y Bas's "Memoria" ' and Brocá and Anell's "Institutions of the eivit law of Catalonia." " Corolen and Pella's ${ }^{3}$ work, the Fueros of Catalonia, may also be mentioned.

The appendices for the other foral territories have not even been redacted, all hough the elenents for their formulation are to be found in the works of dlorales 'for Navarre; l'ipoll" for the Balcaric Islands; Lecauda "for Biscay; and lópez de lago ${ }^{7}$ for Galicia. The texts and full discussions of the laws of Navarte are to be found in the collection by Casteyon ${ }^{8}$ in two volumes, and a briefer work on the general fuere of Navarre by Narregui and Loptuerta ${ }^{9}$ in 1869 . A useful work despite its age is the dietionary by Vanguas ${ }^{10}$ of the foral laws promulgated in Navarre previous to isis. An old but valnable collection ${ }^{11}$ of the furos and privileges of liscay in Biboa during the reign of Charles IV is still referted to.

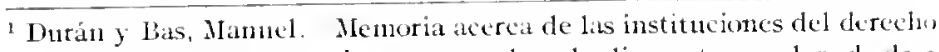
civil de Catalnna escrita con arreglo a lo dispuesto en el r. d. de 2 de febrero de is8o. Barcelona, Cása de Caridad, r88,3. $\$ 06$ P.

2 Brocá Guillermo and Amell, Juan. Instituciones del derecho civil catalán vigente. Barcelona, Barcelonesa, 2 d ed. $1886.2 \mathrm{r}$.

3Coroleu, José and I'ella y lorgas, José. Los fueros de Cataluñal. Barcelona, Administricióta, 18,5.770 1).

* Morales y Gomez, Antonio. Memoria que comprende los principins é instituciones del derecho civil de Navara, que deben quedar subsistentes como excepciön del código genteral, y los que pueden desapareeer viniendo á la unificación decretada con arreglo al real decreto de 2 de febrero de 1880 . Pamploma, Provincial, r884. 2951 '.

"Pipoll y Palon, Pedro. Memoria sobre las institnciones del dereelu civil de las Baleares, escrita con arreglo a lo disquestes cu el real decreto de 2 felorero de 1880. Palma, Ciasil de Misericordia, 1885. 551 .

${ }^{6}$ I.ecanda y Mendieta Manuel de. Legislación foral de Esplaña. Derecho civil vigute en Vizaya, precirlo de la memoria solure las instituciones civiles de aquel país. Madrid, Nuñez, r $888.272 \mathrm{p}$.

7 Iopez de Lago, Rafael. Memoria sobre furers y sociedad gallega, escrita con arreglo a lo dispuesto en el real decreto de a de fubrero de 1880. Narlrid, Min. de Gracia y Justicial, $1885.53 \mathrm{P}$.

s Casteyón, fratnciseo J. Legislación foral de Navarrit. Madtid, Nuñez, 1888. $2 \mathrm{v}$.

Narregui, Palshe and Lopuerta, Segumbo. Finero general de Navara. Paniplona, Provincial, is6o. inz p.

1) Vanguas y Miranda, José. Diccionario de los fueros del reinu de Navarro y de las leyes vigentes promulgadis hista los Cortes de los años I8I7-IS. San Sebastian, Ignaeio Ranún barojus, 1828 . 547 \%).

$"$ Fueros, privilegrios, iranquezas y libertades del $M . N . M$. L. señ rin de Vizcaya. Don Carlos It. Biblbo, Vinda de Antonio de Egasquiar, (no date). $33_{3} 1$. 
The best work of a general nature on foral law is that by Barrachina, recently published. The author discusses its relation with the civil code, its effect on the decisions of the Supreme Court, and on the laws of registration and the notarial system, and presents an account of the different foral systems, e. g., Catalonia, Galicia, Aragon, Navarre, Biscay, and the Balearic Islands. The doctrinal treatise of Falcón, ${ }^{2}$ covering the civil, and the customary law as well, is consulted frequently. The dictionary of Mouton ${ }^{3}$ deals especially with the foral and customary law. Bonel's ${ }^{4}$ four-volume edition of the civil code includes concordances with the foral law in force in the various provinces. It is not considered authoritative though frequently used. The collection of legislation by Maura ${ }^{5}$ covering Majorca, Biscay and Galicia is anthoritative. Another older collection of value covering Castile, Leon, Corona and Navarre by Muñoz ${ }^{6}$ may be mentioned.

The code clenies all value to customs as opposed to statutes, but it admits the suppletory character of local, though not of general, custons in cases where there are no legal precedents or statutes, because dealing with matters unforeseen by the legislator. It is a well-known fact, however, that customs contrary to the statute-book, alike in questions of civil, adninistrative, political or other law, continually arise, frequently prevail in practice, and of ten have general assent. This force of the customary law is discussed in chapter 4 , numbers $1-8$ of Altamira's Cuestiones proliminares (supra, p. 37).

'Barrachina y Pastor, Federico. Derecho foral español. Castellón, J. Armengot thejos, In II-I9I2. $3 \mathrm{v}$.

"Falcón, Modesto. Ixposición doctrinal del dereclio civil español, comín y foral. 6til ed. Barcelona, Ira Publicidad, Tobella, Costa y. Piñol, 1902. 4 v.

${ }^{3}$ Montón Ocampo, Luis. Diceionario del dereclo civil foral, compilado 3 consuetudinario. Madrid, P. Apalategui, rgo, $4 \mathrm{v}$.

* Bonel y Sánchez, Leon. Código eivil español, concordado y domentado con el derecho foral vigente en Cataluña, Aragón, Navarra, y demás territorias aforadas. Con la jurisprudencia, etc. Barcelona, López Robert, $1800.4 \mathrm{~V}$.

${ }^{5}$ Maura y Montaner. Antonio. Legislación foral de Fispaña. Mallorca, Vizeaya y Galicia. Madrid, Nunez, 1888 . $3 \mathrm{v}$. in $\mathbf{r}$

${ }^{6}$ Muñoz y Romero, Tomás. Colcecion de fuctos municipales y cartas pueblas-Castilla, Lcon, Corona y Navarra. Madrid, J. M. Alonso, 18.7. $3 \mathrm{~V}$. 
It must be noted that the actual civil legstation, which includes statutes and the foral legislations, does not comprise all the positive civil law of Spain, bnt that loeal and general custons molded to new conditions flity an important part. Of course, it often happens that the customary law has been reproduced in the written legislation. ()n custonary law the investigations of Costa have probalyly been the most thorough. 111902 he published his "derecho consuthlinurio" ' of Spain, with the assistance of snch eminent jurists and authors as Méntez, Altanira, Iópez, Noran and others. Mhoutón's" brief treatise on customary law discusses the law as it prevails in other continental countries as well as in Spain.

In Catalonia jurists are at present giving mucl attention to the customary law and to the question of how much weight it should be given in practice. A leading work on this topic is that of Forroella ${ }^{3}$, but unfortunately it was written in the Catalan dialeet. Probally in all of the Spanish legal works customary laws are at times mentioned and referred to. (If especial interest is the artiele, El método positizo of Altanira, appearing in the 1992 volume of the journal La nueva cirncia juridica.

The Supreme Court at Madrid passes in the last instance upon appeals from the whole of Spain, thus causing the influence of Castilian law to be felt throughout the l'eninsula. The doctrines of these decisions are having some hamnonizing effect in the confliet of the corle with the foral law.

\section{CONTENTS}

The Spanish civil code is divided into four looks, together with a short preliminary title, which sets forth the jurisdic-

r Costa, Joaquin. Derecho consuctudinario y economía popular de lispaña. Tonro I (Alto Aragón, 2 d.cd.aumentadia) por J. Costa, Tomo II (Zamora, Vizeaya, Asturias, Ciudad Real, Alicante, Leon, Jaen, Burgos, etc.) por J. Costa, S. Méntez, M. Unamuno, M. Pedregal, J. M. Piernas Hurtado, P. Soriano, R. Altamira, J. A. Iopez de la Osa, J. Serrano, V. Santamaria, E. Lopez Moran y G. González de Linares. Bareelona, Nanuel Soler, 1902. $2 \mathrm{~V}$.

2 Moutón y Ocampo, Luis. Derecho eonsuetudinario español y europeo. Madrid, "La Fditora," IgI I. $4+7$ P.

${ }^{3}$ Forroella y Bastons, Juan Btia. Lo droit civil gironi. Mataro, licticia Horta, 1899. 12+ p. 
tion and effect of the laws, and certain general rules for their application, witl a few rules on the conflict of laws.

Book one deals with the law of persons and is divided into twelve titles or sections. Tit le I defines who are Spaniards and who are foreigners, and gives the methods of naturalization. General laws for foreign and domestie corporations and associations are included. Title II deals with the origin and extinction of civil personality, and is itself divided into two chapters, one dealing with natural, and the other with juridical persons, or corporations and associations. Title III deals with donicil, and title IV with marriage, c. g. the forms of contracting, rights and obligations, and divorees, title $\mathrm{V}$ covers paternity and filiation, title VI defunes the support recunired for relations, and title VII deals with the paternal power and its effect on the person and property of the children, and includes adoption. In title VIII the results and effects of absence are shown. Title IX covers guardianship and titIes X, XI, and XII deal respectively with the family conncil, emancipation and majority, and the registry of civil status. It may be stated that the family council is one of the remarkalle adoptions of foreign institutions by the code which have often not unjustly incurred the criticism of the profession.

Book two takes up the laws of property, ownership and its modifications, and is divided into eight tilles or sections. Title I classifies property into real and personal, and divides it into things pertaining to the public domain and private ownership. Title II deals with ownership, rights of accession and rules for boundary lines. Title III treats of the obligations and rights of joint owners. In title IV sonne special forms of property are dealt with, such as waters, use of private and public waters, mineral ores, and intellectual property. In title $\mathrm{V}$ the laws of possession, its acquisition and effect are covered. Usufruct, use and habitation, easements and servitudes, and regist ration of property are covered in titles VI, VII, and VIII, successively.

Book three, which deals with the different ways of acpiuring ownership, is divided into three titles or seetions. They treat of adverse possession and acquisition of property which has lad 110 forner owner, donations or gifts, and successions. Sncessions are subdivided into testanentary and intestate. 
Book four is the longest and deals with obligations and contracts, dividerl into is sublueads or titles. Fitle I, on "obligations", disensses the general nature, extinetion and the evidence adnissible in the proof of obligations. Title $I 1$ is headed "contracts", and all the other sections are really parts of this. The essentials of a contrict, contracts relating to property on account of marriage, paraplerna, conjugal conmunity, contracts of pureliase and sale, harter or exchange, contraets of lease, rents, partnership, ageney, loans, deposit, aleatory contracts, empronises, sceurity, contraets of pledge, mortgage, quasi-entracts, concurrence and preference of credits, (civil law institutions) and prescription (both of ownership and of actions) are all dealt with in the order mentioned.

The code ends with a seetion of provisions for its applieations to aetions and rights acquired previously to its adoption and also provides for a revision of the code every ten years, a provision which has not been carried out.

\section{GENERAI, I,TTIRATLRE}

There have been two transiations of the civil code into Finglish and one into French. By royal deeree, July 31 , I 889 , the code was extended to the islands of Cuba, I'orto Rieo, and the Plilippines, to go into effect twenty days thereafter. The administration of these islands by the United States following the elose of the Spanish-Aneriean War in 1898 required the translation of this code into English. In I S99 a translation withont annotations or notes was prepared by Walton and De Ifeon. ${ }^{1}$ Walton republished this translation in $\mathrm{r} g 00$ in his "Civil law" of Spain and Spanish Aneriea," (sufra, p. 36) with eitations to the laws on which the different chapters and subjects are based, and to some Spanish-Anserican civil codes nuder the cortesponding artieles. The War Department of the United States isstred a translation ${ }^{2}$ in 1899 of the Spanish code in force in the new Anerican possessions. This translation may also be

${ }^{1}$ Walton, Clifford S., and Ponce de Leon, Nestor. The Spanish civil code, translated. Havana, La propaganda literaria, 1890. 368 p. ${ }^{2}$ Division of Customs and Insular Affairs. War Department. Translation of the civil cole in force in Cuba, Porto Rico and the l'hilippines, with alphabetical index. Washington, Government Printing Olfice, $1899.322 \mathrm{P}$. 
found in the last volume of the "Laws, ordinances, etc., effective in l'orto Rico May I, 1900." " This work includes translations of the civil, penal and commercial codes, the codes of criminal and civil procedire, the mortgage law, public service law, etc. These are all useful to the student of Spanisli law, in view of their practical identity with the laws of Spain. The translations are too literal to be considered good. A French translation " of the civil code has been made by A. Levé, a second dition of which appeared in 1904 . There is a general discussion of the code in the introduction, and the difierent sections are annotated with reference to corresponding sections in the French and other foreign codes.

Spanish editions of the civil code vary in size and manner of treatment. The editorial staff of the Revista de los tribunales publishes new editions of the code from time to time in handy and convenient form. Their latest edition ${ }^{3}$ appeared in 1912. Garcia Horeno ${ }^{4}$ recently (1913) published an edition of the code as in fores in Spain and Cuba. The amendments and additions with judicial decisions in both Spain and Cuba up to r9r 3 are inserted as annotations. Attention may also be ealled to the "reference manual" of Spanish law by Medina and Maranon," which is used currently by the profession. This small volume contains the civil and commercial codes, the nortgage law, the law of civil procedure, the Constitution of 1876 and the principal legislation through igr . Nartínez Alcubilla, "whose Diccionario (supra, p. I6) is the standard encyclopedia of Spanish law has re-

${ }^{1}$ Division of Customs and Insular Affairs. War Department. Laws, ordinances, decrees, and military urders having the force of law, effective in Porto Rico, May I, rgoo. Washington, Government Printing Otfice, I9og. $4 \mathrm{v}$.

${ }^{2}$ Levé, A. Code civil espagnol, traduit et annoté. 2 d ed. Paris, A. Pedone, r9o4: $35+\mathrm{p}$.

${ }^{3}$ Código civil español, cuidadosamente revisado. Madrid, Góngora, 1912. $4041 \%$

* Garcia Moreno, A. Código civil vigente en España y Cuba, con varias leyes y otras disposiciones complementarias . . 3d ed. Madrid, Artística española, IgI 4 . S21 p.

5 Medina, León y Marañón, Manuel. I.eyes civiles de España conformas á los textos oficiales. Novísina ed. Madrid, Los Hijos de Tello, 1911. 1+22 p.

c Marlínez Alcubilla, J. Código civil. Madrid, Administración, 19 3. $1171 \mathrm{p}$. 
cently (1913) published a most conplete atition of the code with numerous citations to his large work. 11 is in facl a digest of references to civil law included in his encyclopedia, which has grown cumbersone by many additional supplements.

The provision in the cole for complete revisions every io years has resulted in but slight changes and those usually in nunor details. There lave been numerous legislative enactments and many court decisions relating to the inclividual sections of the code. In these matters, Calvo ${ }^{1}$ has furnished an exceedingly useful aid to the study of the cole. His work, which appeared in 1912 , is an index of all the relevant legislation and court decisions chronologically arranged under each section of the code. References are made to the Gareta (supra, p. I I) and Martínez Alcubilla's monumental encyclopedia (supra, p. 16), where the texts of statutes and decisions may be found.

There are two standard commentaries (comentarios) on the civil colke, possibly of equal value. Manresa, ${ }^{2}$ a justice of the Suprene Court and a nember of the Code Commission, has published a 12 volume edition with the collaboration of various lawyers. Scaevola's "Civil code" 3 is an even more extensive commentary. It embraces $2+4$ volumes and 2 supplements, the latter dealing with certain special topies. "1he period of publication covered the years $1902-1909$, and there is now in preparation a new edition, of which nine volumes lave appeared. A part of book IV of the code has never been covered by the original work.

A scientific and thorough criticism of the code is the " $L a$ revision" by Conlas, ${ }^{4}$ who is a professor and former dean of the lizculty of law in the University of Madrid, as well as a member

' Calvo y Camina, Pedro. Ixgislación y jurisprudencia relativas al código civil. Madrid, Hijos de Rens, rgr2. 568 p.

a Manresa y Navarro, José Maria. Comentarios al código civil español. Madrid, Rev. de legislación, 1903-1907. $12 \mathrm{v}$.

${ }^{3}$ Scaevola, Q. Mucius. Código civil concordado y comentado extensamente con arreglo a la edición oficial. Madrid, Obras de Mucius Scaevola, [etc.] 1902-1909. 2.4 vols. and 2 suppl.

+ Comas, Augusto. La rcvisión del código civil español. Madrid, Huérfanus, $1 S_{95}-1902.6 \mathrm{v}$.

$77231^{\circ}-15-\ldots$ 
of the General Code Commission. He discusses the necessity of a reformation of the code and takes 11p each section inctividually. A "proyecto de reforma"1 or a proposed model is submitted by the author.

A few treatises in English on Spanisl civil law have been published, botli before and after the adoption of the code of 1889. An Englishman, Lewis F. C. Jolnnston, ${ }^{2}$ in 1825 , made a translation, with copious notes, of the "Institutes of the civil law of Spain" (6t1 ed., 1 So5) by Asso and Manuel. The translation was prepared for the benefit of English lawyers, upon the acquisition of the island of 'Trinidad by England. The work is divided into three books which treat respectively of persons, things (including crimes and punishnents) and actions (eivil and crinimal). It contains the substance of the statute and common law of Spain at that date. In $18_{5} 1$ Schnidt pul lished in New Orleans a treatise on the civil law of Spain and Mexico (supra, p. 37). The work is arranged on the principles of the spanish codes in force in i $S_{5} \mathrm{I}$, wit h notes and references. Walton's "Civil law in Spain and Spanish America" has already becin mentioned (supra, p. 36). This work is useful to Englislispeating people becanse of the lack of English works on Spanisli law, but the author is not always accurate. Its contents include a translation of the civil code and its annendments, short sketches of the cockes of civil and criminal procedure, an ontline of the law of nortgages and also a translation of the constitutions of Cuba and Nexico in force in 1900.

A two-volune clenentary treatise on Spanish eivil law, published in Irench by Eimest Lehr, ${ }^{3}$ warrants mention. The lirst volume appeared in 1880 , before the arloption of the Corie of 1889 , and the sceond rolume in 1890 .

spanish treatises on the civil law vary greatly in size and inportance. The leading work is the Estudios of Sanchez Ronain," a professor in the University of Madrid

i Connas, Augusto. Proyecto de reforma de] codigo civil esjatnol. Madrid, Iluérianos, 895 . I $900.2 \mathrm{v}$.

"Foluston, Lcwis 1:C. Institutes of the civil law of Spain by lgnatius Jurdan de Asso y Del Rio and Miguel de Manucl y Rodriguez (6th ed. Hidrid, 1S05). Transiated from the Spanish with notes, an appendix, and index. I,ondun, A. Strahan, 1825. 5351 '.

"I.chr, lirnest. lífénents de droit civil espagnol. Paris, L. Laruse et fiurcel, $1880,1800.2 \mathrm{v}$.

+ sitpra, 1. +1 . 
and at member of the Corle Comminsion. The first fohne contains a valualle general history of Spanish legislation. In separate volumes, the common and foral laws, the law of property, contracts, family relations and succession are taken up. The "notes" (afuntes) of Prof. Clcmente de Diego," alsu of the University of Nadrid, and director of the periodicial Revish de doccho prizado, are to some extent sujerseding is a treatise the work of Sánchez Román and enjoy consielerable authority. Unfortunately its value was kssened by the form of its appearance, but in this year $(191+)$ a new edition in reatable type is in course of publication. Buron ${ }^{2}$ has publisled a work on the civil law combined with a project of reforntion of the code. Prof. Calabuig, of the University of Valencia, in 19r2, published the first volume of his "Studies" on the civil law of Spain. The part already in print is complete in itsell, being a general discussion of the coneeption, the theory, and the essential elements of civil law. "lhe parte eperibl, or part dealing in detail with the institutions of civil law, is now in preparation. Talverde is at present (194 publishing at tratise on the eivil law, thece volumes of which appeared in 1913.

There are two important annotated editions of the decisions: on the civil code which may be mentioned. Mncins Scarvola," who produced the roluminous commentary on the civit code, edited a set of the reports from 1889 to 1en in seven volumes, arranged in accordance with the civil cocke. Anmul supplementsextend the work to agos. Volnmes bringing the decision down to date are in course of pullication. I convenient edition of the decisions on the civil code, followed ly four indices for easy consultation, has been compiled by a

'Clemente de Diego, lelipe. Apuntes de derechn civil. Madrid, Suarez, IgIt. $8 \mathrm{v}$.

2a liurún y Garcia, Gregorio. Derecho civil espanol según los principios, lus cudigos y leyes precedentes y la reforma da cónligo civil. Valla dolicl, Audrés Miartin, 180S-1000. 3 Y.

${ }^{3}$ Callabuig y Carra, Vicente. Fistudios solure de dercho divil cspañul. Parte general. Valencia, Hijus de l'. Vines Mtra, igra. 483 p.

- Valverde y Valverde, Calixto. Tratado de derecho civil espinini. Madrid, Marcías Picancaz, IฤI3. 3 v. to date.

${ }^{5}$ Scacvola, Q. Hucius. Jurisprudencia del código civil. Sentencias y repuestas. Expmesta y comentada. Nadrif, Imprint del antor

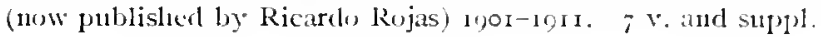


jurist who sigus his name V. A. M. ${ }^{1}$ These reports commence in 1889 and extend to the present day.

\section{INDIVIDUAL PARTS OF THE CODE AND RELATED SUBJECTS}

The various divisions of the code have been the subject of individual treatment in a number of important works, to which attention may be called. Several of the larger general works previously cited, especially the treatise of Sánchez Ronan (supra, p. 4I), include full treatments of the individual parts of the code.

\section{PERSONS}

The cocke in titles one and two of book I covers explieitly citizenship and naturalization and divides persons into two classes, natural and juridical. The formation and governing laws of eorporations and companies are discussed under mercantile law (infra, p. 72 ).

The forns and requirements for the contraction and celebration of marriage were formerly left to the canon or ceclesiastical law, but under the code of 1889 a civil nuarriage is provided for, with the exeeption (art. $4_{2}$ ) that all who "profess the catholic religion must celebrate the canonical form." A royal dectee was issued March 19, 1906, in regard to the secret civil marriage. Emile Stocquart, who has made a study of the Spanish marriage laws, published several interesting articles on the subjcet. In r 904 he published a description in French of the law of marriage under the early Spanish codes, in volume 36 (1904) of the Revue de droit international, pages $585-603$. Some years previously he discussed in English the Spanish marriage laws and their extra-territorial cffect, in volume 25 (IS91) of the American Law Review, pages 82-95. He compared the Spanish and French laws in the third volume (1910) of the Annual Bulletin of the Comparative Law Bureau, pages 25-38. A practical treatise or 1 lanual on marriage by I, astres, ${ }^{2}$ in his "popular jurisprudence" series, appeared in a

IV. A. M. Jurisprudencia referente al cóligo civil glosada, concordada, ete. ... Midrid, Ricardo Rojas (now published by Leopoldo Martínez), 1894-1012. Ig V.

2 Lastres, Francisco. F1 matrimunio. 31 ed. adjustada al códigu civil. Madrid, V. Sturez, rSSy. 2 I 4 p. 
third edition innuediatedy following the promulgation of the code of 1889 . Cardenas ${ }^{1}$ in volume II, pages $1-117$, of his “juridical studies” presents two interesting listorical nonographs on the effects of nuariage on projerty. An interesting article on the Spanish law concerning breach of promise to marry as conpared with Anerican law appeared in volune 43 (1909) of the Anerican Law Review, pages $759-769$. It is in fact an opinion by Jugge 1,obingier in a case in the Plinlippine Islands.

All positive law relating to women in Spain, witl annotations and comments, was compiled by Diez Enríguez ${ }^{2}$ in 1903. Books on the legal condition of wonan by Ferreiro Lago, ${ }^{3}$ and the "married woman and the civil code" by Villar and Martínez Acacio* nay be nentioned.

In his "popular jurisprudence" serics, Lastres has issucd treatises on filiation, family rclations, ${ }^{5}$ and guardianship," which have mndergone new revisions in accord with the civil code. The legal condition and social problem of illegitimate children appears to be a more injportant question in Spain than in America, due to the position the govermment has taken in supporting bastards. A modem discussion of this question, following the legislation to 1906 , was published $\mathrm{by}$ Angtlo. Infants' contracts, or their capacity to assume legal obligations, is covered in a work by Ranos. ${ }^{8}$

1 Cardenas, Francisco. Fistudios jurídicos. Madrid, P. Nuñez, Is\&4. $2 \mathrm{v}$.

${ }^{2}$ Diéz Enríguez, Dronisio. El derecho positivo de lat mujer. Madricl, Góngora, 1903. $380 \mathrm{p}$.

${ }^{3}$ Ferreiro Lago, R. Condición jurídica de la mujer. Fistudins filosófico, listórico y del código civil. Valladolid, Santaren Mladrazo, Inoz. $108 \mathrm{p}$.

"Villar y Peralta, Luis and Martinez Acacio, José. La mujer casada y el código civil. Madrid, Alonso, ISo.4. I35 p.

${ }^{5}$ Lastres, Francisco. Filiación. Patria potestad. Alimentos. ad ed., adjustada al código civil. Madrid, V. Suarez, i\$go. $200 \mathrm{p}$.

${ }^{6}$ Lastres, Francisco. Tutcla y consejo de familia. zd ed., adjustaclat al cóligo civil. Madrid, V. Suarez, r\$go. $201 \mathrm{p}$.

${ }^{7}$ Angulo y Laguna, Diego. Estudios sobre la condición juríclica de los hijos ilejtímos según los principios y el código civil vigente. zd ed. Madrid, Hijos de Reus, soo6. 212 p.

${ }^{8}$ Ramos, Rafael. Capacidad de los menores para contratar y obligarse

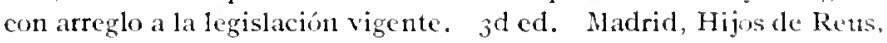
$1907.5001 \%$ 
A leading wotk on guardianship is the commentary by Penichet. ${ }^{1}$ The family council, or the consejo do familia, is peculiar to civil law countries; there is no exactly sinilar institution in the United States. It is composed of relations appointed by law (unless provided for by will) who, among other guardianship duties, perform some that fall upon our probate conris. A treatise on this subject by Arce $^{2}$ was prepared immediately after the code was adopted. A more modern (1905) work is that of Ribera. ${ }^{3}$

As has been stated, the large general works contain full, and possibly the best, accounts of the individual parts of the code. This is true of the registry of civil status. The laws coneerning registration of births, deaths, marriages, cte., are more rigidly enforced in the countries of Europe than they luave been in to this time in the United States. The legislation governing the eivil register was compiled in 1907 by the editorial house of Góngora." Abella's ${ }^{5}$ manual may also be mentioned. The older treatise of Fernández Giner ${ }^{6}$ is still of value.

PROPERTY

'The law of property in a civil law country such as Spain has many difficulties for the lawyer trained in the common law. In the years 1879 to 188.3 . Azcárate ${ }^{7}$ published a lengthy history of the property law of Europe and its actual status. Laws of mortmain and entailment of estates in Spain are disenssed in the brief but raluable work of the present prime

${ }^{1}$ Penichet y Lugo, Franciscu. Comentarios á la tutela. Madrid, Hijos de Reus, I899. 4241.

2 Arce y Rodriguez, Angel de. Él consejo de familia, la tutela, y la protutela. Marlrid, T*é, I890. $232 \mathrm{p}$.

3 Ribera Cañizares, M1. Prontuario del consejo de familia, de la protutela y de la tutela. Madrid, V'. Sutarez, Igos. 2 v.

${ }^{4}$ Legislación de registo civil desde su creación lasta el día. Madrid, Góngora, I907. I v.

5 Abella, Fermín. Manual del registro civil. othed. Madrid, Admin istración de "lil Consultor," 1003. I ro p.

" Finrnández Giner, José. Tratado completo del registro civil. Madrir. Aurelio J. Alaria, IS79. I 28 p.

7 Acárate, Gumersindo de. Ensayo sobre la historia del dercelo de propiedad $y$ su estado actual en Luropa. Madrid, Rev. de legislación, $1879^{-1883} .3 \mathrm{v}$. 
minister, Naura. Antequera " has published a treatise upon the disentailment of ecelesiastical lands. The latest mannal of ciril and ecclesiastical mortmain laws by Aparici ${ }^{3}$ appeared nearly fifty years ago. (See also p. 1 rg, infra.)

\section{LITERARY AND IXDESTRAA. THUPERTY}

The subjects of literary and industrial property (propidad literaris $y$ industrial) received little treatment in the civil cole, hit are dealt with fully in separate statntes. The carliest recognition of the rights of atuthors was sanctioncel by the deerce of Charles III in 1764 . The recognition of wher kinds of intellectual property, such as paintings, musical and dramatic works, maps, etc., subsequent ly took place grallully.

In the third volume of the Law Magazine and Review (18,7 1878 ), fourth series, pages $+27^{-}+59$, there was publislied an article dealing with copyright reform in Belginm, Spain and England. The draft law as presented to the Cortes in 1877 is translated into Inglish at pages $+42-453$. This law was adopted Jan. 10, I 879 and was followed in 1880 by a reglamento or regulation for carrying it into effect. Since that date there have been but few additions to or changes in the statute." A good manual of the laws governing literury property, by Soto y Hernández, ", contains all the legislation and relevant decisions to the date of publication, including the Berne convention of 1886 . In the appendix accounts are given of the Society of Spanish authors and the Association of the Press. Another manual of convenient size was pullished by the law librarian of the University of Madrid, Cas-

'Maura y Montaner, Antonio. Propiedad de personas juridicis. Anortización, vinculación. Madrid, M. H. Hemántez, 1897. $46 \mathrm{p}$.

2Antequera, José M. La desamortización eclesiástica considerada en sus diferentes aspectos y relaciones. Madrid, Perez Dubruli, is85. 5 I 01 .

3 Aparici $y$ Soriano, Ricarto. Mamual novisima de la desimortifacion civil y celeciástica. Madrid, Tejado, 1868 . $525 \mathrm{p}$.

4 Spain has been liberal in granting copyright proteclion to foreigners. In view of the protection granter to American cirizens, the benefits of the United States colyright acts of 1891 and mon were extender to spanish subjects by presidential proclanation of 1805 (remewed in 1902 ) and 1910.

$\therefore$ Soto y Hernandez, Antunio. Manual de la propiedul literaria, artistica y dramátiea . . Madrid, Góngora, I902. $240 \mathrm{P}$. 
tillo. ${ }^{1}$ A bibliography of foreign and Spanish works on the subject is included. A work by a South American, Rios, ${ }^{2}$ of special interest to the Latin-American republics, discusses the bases for a treaty between American republies and Spain. The distinguished jurist Conzález Hontoria ${ }^{3}$ in 1899 made a colfection of the treaties in regard to intellectual property between Spain and Spanish-American countries.

Estasén " has published a complete work on the industrial law of Spain in which industrial property is fulty covered. The treatise also discusses the labor laws and until 1902 was probably the most tuseful single work on the subject of industrial law. Since the enactment of the patent and trade-mark law of 1902, however, it has lost some of its usefulness.

The law concerning the protection of industrial property is found in the statute of 1902 , la ley de propicdad industrial de i6 de Mayo de 1902 y' su reglamento de 12 de Junio de 1903 (with the royal order of July 26, 1905, explaining article 109 of the law). There were various other statutes enacted prior to this act of 1902 which was the constmation of a complete "code" on the strbject, and is now in force. It includes the laws of patents, useful models and designs, trademarks, trade names, unfair competition, and the protection of industrial prizes or honors legally awarded. The aet in complete form was translated into French by Carpentier ${ }^{5}$ in 1904. This edition is wetl arranged and conveniently indexed. The sane author discussed the law at length in volume 31 of Clunet (1904), pages $8_{32}-S_{41}$. Singer ${ }^{6}$ in his work on patents and trade-mark laws of the world devotes pages 396-401 to a discussion of patents and pages $401-403$ to trade-mark law

${ }^{1}$ Castillo y Soriano, José del. Nanual legislativo de la propiedad literaria $\mathrm{y}$ artistica. Madrid, M. Romero, igor. $285 \mathrm{p}$.

${ }^{2}$ Ríos, Cornelio. De la propiedad literaria; bases para un tratado cntre las repúblicas americanas y España, Buenos Aires, J. Penser, Ig05. I $\mathrm{v}$.

${ }^{3}$ González Hontoria, Manuel. Los convenios de propiedad intelectual entre Espana y los paises ibero-americano. Marlrid, Minuesa de los Rios, I $890 . \quad 38 \mathrm{p}$.

4 Estasén, Pedro. Derecho inclustrial de Ispaña ad. erl. IBareelona, I.. Seiz, I901. 94 r. P.

${ }^{5}$ Carpentier, Paul. La loi espagnole sur la propriété inclustrielle du i6 Mai Igo2. Paris, A. Chervalier-Mareseq Co., I904. 136 p.

"Singer, Bertholdo. Patent ancl trade-marliaws of the world. Chicago, Hammond Press ( $\mathrm{H}$. Iz. Conkey and Co.), IgI I. 539 J). 
in Spain. A translation of the texts of the law is not given. Pella ${ }^{1}$ published a nseful treatise on patents which he revised in concordance with the act of 1902 . The work is intended for the use of inventors and numufacturers as well as lawyers. A more recent prictical work by Rossello ${ }^{2}$ of Catalonia was published in 1907 , giving the court decisions on the subject. The first volume, covering inventions, of Professor Ramella's ${ }^{3}$ well-known Italian treatise on industrial property appeared in a Spanish translation in 1913. The work will enconpass two volumes when completed.

EMINENT LOMAIN

The third book of the civil code deals with the differcnt methods of aequiring ownership of property. The laws for the taking of private property for public use through the power of eminent domain may be appropriately mentioned at this point. It is interesting to note that the civil code (sec. 349) contains a provision that private property slall not be taken for public use without due compensation-correspondins exactly with our constitutional provision. Article 1456 provides that forcible expropriation on account of public utility shall be governed by the provisions of special laws. The special laws in force are comprised in the act of January ro, 1879 , which was followed on June 13,1879 , and March 10. ISS I, as is customary in Spanish legislation, by regulations for its application. Article 29 of this act, dealing with the survey of the estate and the appointment of experts, was modified by the statute of July 30,1904 .

The act of 1879 was extended in 1884 to Cuba and Porto Rico. The IVar Department in its translations of the laws of Porto Rico (supra, p. 48 ) includes this law also, with a complete index. The translation ${ }^{4}$ can be obtaned separately also.

${ }^{1}$ Pella y Forgas, José. Nuevo tratado de patentes de invencion con arreglado a la ley de propiedad industrial de i6 de Mayo 1902 y su reglemento de 12 Junio de 1903. Barcelona, José Fispaca, Ino. . $235 \mathrm{p}$.

2 Rossello, Antonio. La propiedad inrlustrial y leyes que la regulan. Madrid, Hijus de Reus, $1907.58+1$.

${ }^{3}$ Ramella, $\Lambda$. Tratado de la propiedad industrial. Tomo I. Inventos industriales. Madrid, Hijos de Reus, I013. Vol. 2 in publication.

4 Division of customs and insular aliairs. Translation of the law of eminent domain extended to Cuba and Porto Rico by r. d. of Junc $I_{3}, 188_{4}$, and regulation for its application. Waslington, Governnent Printing Ofice, rgor. 61 p. 
Abella's ${ }^{1}$ mantial of the law of eninent domain was revised in 19I. A treatise by Melgar ${ }^{2}$ published in 1889 and a later work by l'iernas ${ }^{3}$ may be mentioned.

SLCCESSHUN ANL IDECENT

The corle devotes considerable space to the matter of descent of property aud succession (sucesiones). Articles oss and 7,32, which deal with holographic instrmments, were modified by the act of July 21, 190. A special institution of the (ivil law, the compulsory portion, according to which a father or mother can not disinherit the legitinate children. was adopted in Spain. Two-thirds of the estate are thus reserved. la Coste ${ }^{1}$ has reeently written in French a nonograph on the mejora or compulsory portion, discussing its history and theory, and conparing it with sinilar institutions of foreign countries.

Spanish treatises and other rorks on succession are numerons. The sections of Sinchez Román's treatise devoted to the subject are especially valuable. A practical work is that of Ramos, in which the changes are noted and the decisions of the courts are cited up to i 898 , while a more theoretical one is the treatise of lopez y (oonlez." Fixecutors and administrators are discussed in a work published anonymonsly ${ }^{7}$ in ISgo. Villalobes Lopez's ${ }^{8}$ practical treatise on the distribution of estates may also be mentioned.

1 Abellat y liave, Iermin. Mantal de expropriacion forzosa y obras públicas. fth ed. Madris, Administraeión, IgIr. 808 p.

- Melgar y Abreu, liarnardino de. Tratado de expropiación lorzosa por causa de utilidarl pública. Madrid, M. Romero, $1889.386 \mathrm{p}$.

${ }^{3}$ Piemas y de Tineo. J. La"xpropiación forzosa. Legislacion española. Madrid. V. Suarez, I008. $256 \mathrm{p}$.

* La Coste, Georges de. Fissa sir les mejonus on avantages légitinaires dani le droit espatgmol ancien et nuderne. Paris, Arthur Roussean, I91I. $524 \mathrm{P}$.

- Ramos, Rafacl. De las stucesiones. 'Tratado téorico-práctico según el códigro civil. Madrid, Ruv. de legislación, 1896-r8gs. 2 v.

"Inpez y Gonez. Nicolás. Tratado teńrico legal del derecho de sucesión. Valladolid, Pastor, I89i, 1803. 2 v.

7nonimo Testanentarios y abintestatos. Madrid, Ricardo Alvarez, ISno..$\$ \$ 6 \mathrm{p}$.

8 Villabibos 1.ipez, Valcrio. Tratado teórico-practico de particiones de herencia conforme al código civil. 3d ed. Madrid, Hijos de Carcia, 1901. 350 1). 
OBIHOTHONS AN1) CONTRACTS

Book four of the cole undertakes in doal fully with the subject of contractual and quasi-cont ratenal obligations. the "general part" of obligations and contracts, which ineludes the lwo first titles of the fourth book and clapter II of titk" Xl't of the same book, may also be considered mercantile. laws, since their application to questions of this nature is recognized by article 50 of the code of commerce.

Probably the best anthority on the liw of olligation and contract is the fourtl volume of Sinchez Ronvin's Estudios de derecho ciall (supra, p. 41). Clennente de biego's treat. ment (supra, 1. 51) of the suljeet is consicleted by mans. however, to le of epual value. I Spanish translation of the seventl efrition of the "theory of obligations" by" the Italian

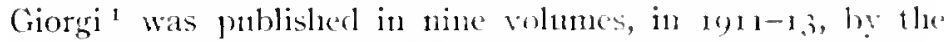
editorial staft of the Reriste foucral de legislación y jum. prudincia. This voluninous work contans, besides an int whduction by Dato, annotations of the laws of Spain and Spanish-Anerica with the decisions of the supreme Court of Spain. 'There is an elementary treatise, by Otero,? which explains in detail book four of the code.

In addition to the more general works nnmerons treatnents of special Lopies have appeared. Infants' contracts and obligations are completely discussed by Ramos (supra, p. 53). A lucid work on the contractual succession to property hy García Herreros ${ }^{3}$ warrants mention. A more scientific and profound work is that of Castillejo, which was rewarded with a prize offered by the University of Madricl. The assignment or transfer of obligations has been treated of hy Prof. Clemente de Diego ${ }^{5}$ in a recent work (1912).

'Giorgi, Jorge. Teoria de las obligaciones en el derecho civil moderno. Translation of th ed. Madrid, Rev. de legislacion, 1011-1913. $9 \mathrm{~V}$.

${ }^{2}$ Otero y Valentin, Julio. Tratado elemental del derecho de obligations's según el libro IV del código civil español. Con un prólogo de Lorenzo de Prado y Fernandez. Valladolid, Cuesta é Hijos, i8n3. $51 \mathrm{I} \mathrm{p}$.

${ }^{3}$ Garcia Herreros, Enrique. Ia sucesion eontractual. Prölogo de Ralatel de Ureña. Madrid, Hijos de Hernández, Inoz. 149 p.

"Castillejo y Duarte, Jose. La reforma contractual en el dereche de sucesiones. Madrid, Hernández, I902. I70 l".

${ }^{5}$ Clemente de Diego, F. La transmisilsilidarl de las obligaciones. Madrid, I. Suarez, 19r2. $352 \mathrm{p}$. 
Rents of lancl or ground rents (censos) are treated of in title seven. In Spanish law there are several distinct kinds of rents as the emphyteusis (censo chfitcusis), local ground rents (foros), the reservative and consignative rents, etc. Sanclez de Ocaña has published a wotk which enumerates and riscusses these fully, trating of their history and the legislative and customary laws affecting them. A manual relating to leases and loans in accordance with the civil and conmercial coles was published in $889 \mathrm{by}$ Abella. ${ }^{2}$

MORTGIGES (HPOTECAS)

The civil code provides only briclly for the contract of n1ortgage. In article 1880 it is stated that the "form, extension and effects of the mortgage and also whatever relates to its constitution, modification, and extinction, and all that has not been comprised in the chapter shall remain strbject to the provisions of the law of mortgage which continues in force." Therefore it is neeessary to cxamine the legislation sepatate from the code. Up to $186 \mathrm{r}$, both the laws and decisions o:1 mortgages wete conflicting, resulling in much confusion and instability in the value of the n110rtgage. In 1855 , a commission was appointed to frame a general nortgage law to take the place of all the special legislation with its contradictions. Two projects (projectos) were submitted by the eommission to the Cortes and finally after many revisions a general law was promtlgated, February 8, 1861. 'This law was revised in 1863 and I 865 , and finally the law which is practically the one now in force was adopted, December 21, 1869 . This law with its regulations of October 28,1870 , went into effect Jantuary $\mathbf{I}$, 1871. It continued in effect as a whole, with a few modifications due to the civil corle of 1889 , until r 909 , when some leeded reforms were instituted.

The law of mortgages is composed of fifteen titles, eomprising over foo articles. The instruncuts requiring record, the method and effects of the record, cancellation of record, kinds

'Sánchez de Ocaña, Ramón. Estudio critico de las diversas especies de censos. Madrid, los Huérínos, isg2. I66 p.

2 Abellar y Bave, Fermin. Manual de arrichlos y préstamos con arreglo A los vigentes codigos civil y de comercio. Madrid, Administración, 1850. $34 \mathrm{I} \mathrm{p}$. 
of mortgages; the manner of keeping the registries and various other topies are covered. In addition there are rules for the applieation of the law and a tariff or sehedule of fees. The law of 1909 contains six general title heads, subdivided inlo +3 articles, which extend the business use of mortgage, and change the forms of recording, as well as some provisions concerning ancicut entries.

the mortgage law was extended to Porto Rico, Cuba, and the Philippines in i 893 . The law there underwent sone necessary elanges but is in substance similar to the law of Spain. A translation of this law was made by the War Department "with the general regulations for its exceution. A translation of the general law of 1861 was made by William Grain," an Inglisiman. A short glossiry of Spanish terms used therein is included.

The many works on mortgages indieate the innportance of the subject in Spain. An edition of the law as changed by the new reforms of April 2I, 1909, was issued in 1910 by the Revista de legislación. Vila $^{4}$ published in 1913 a well annotated cdition of the mortgage law as changed by recent legislation. The work is really a bricf commentary. Aragones ${ }^{5}$ edited a "compendium" of mortgage legislation in $191 \mathrm{r}$, and also, separately, a brief discussion with the texts of the changes made by the law of 1909 . What was generally considered the best conmentary on mortgage legislation before the new

1 Translation of the mortgage laws for Cnha, Puerto Rico and the Philippines. (1S93). By Inited States War Department, Washington, Government Printing Office, I 899 . $90 \mathrm{p}$.

Same. General Regulations for the execution of the mortgage law ... Waslington, Government Printing Office, ISpo. I52 p.

:The lcy hipotecaria of Spain. Translated and edited by William Grain. ... London, H. Sweet, 1857 . It9 1".

"Nueva ley hipotecaria, públicada por real decreto de licimbre de rgog en complimento de la sexta disposición adicional de la ley de $2 \mathrm{r}$ de abril del mismo año. Madrid, Rev. de legislación, yog. $92 \mathrm{p}$.

'Vila Serra, José. Novísima legislación hipotecaria. Valencia, Inpr. del iustor, 1913. 708 1 .

${ }^{5}$ Arngones y Carsi, Pascual. Compendio de legislación hipotecartia. Madrid, V. Suarez, Inog-1911. 2 v.

Same. Modificación de algunos artículos de la ley hipotecaria por lat de 22 abril de r909. Madrid, Góngora, 1909. $135 \mathrm{p}$. 
changes in the law is that of Calindo and Escosura, the fourth edition of which appeared in 1903. It should be noted that the third edition contains the law as enforeed in Cuba, Porto Rico and the Plilippines with some comments. Another valuable commentary in current use is the work of Nartinez Noreda," although it has not been revised since 1906. A recent (1912) work is the "Mlortgage legislation" of Diaz Horeno. ${ }^{3}$ This work is arranged in form of replies or expositions to the program, or list of topics, for the first examination of applicants for registers of property. It diseusses the different topics at some length and includes the law of 19u9. The decisions of the Supreme Conrt from 1861 to becember $3 \mathrm{I}, 1900$, have been topically arranged in alphalx tical order by Ordriozola. ${ }^{4}$

Atcention may be called to a few of the more important treatises. A recent (1912) comprehensive work on the subject of nortgage, and also notarial law, in four volumes was published by Barrachina, ${ }^{5}$ an eninent jurist. The nortgage act of 1909 is thoronglyly discussed. Oliver "has written a "fundancutal and systenatic exposition of the law of mortgage" in force in the Peninsula and the foreign colonies. it work on the law of pledges and securities for loans, with cspecial reference to agriculturists and famers, was publislled Wy Ramos in 1910. It includes nore than the title inuplies as the anthor devotes a portion of the work to

${ }^{1}$ Galind"y de Vera, Leom; and Escosura y Iscosura, Rafael de la. Comentarios a la legislacion hipotecaria de lispana. 4thed. Madrid, Antonio Marzo, 1903-1904. $5 \mathrm{v}$

2 Martincz Muredab. M. Comentarios y jurisprudencia a la legislación liputecaria en furma alfabética. Madrid, Bailly-Halliere e Hijos. rool. $2 \mathrm{v}$.

"Diaz Mroreno, linstaquio. Legislaciun hipotecaria. Marlrid, A. Marzo, I011-IOI2. 2 V.

"Odriozolib y Grimand. Carlos de. Diccionario de jurisprudencia hipo. iccurit de Espraia ... desde el año 156 r hasta z r de diciembre de 1900. Misdrid, I,eupuldo Martínez, igor. 1 i $561^{1}$

" Marrachina, Federico. Derecho hipotecario y notarial. Castellón, J. Armengotthejes, $1910-1912.4 \mathrm{v}$.

"Gliver y Fisteller, Bienvenito. Derecho inmobiliario español. Iispo sichiof fundatucntal y sistematica de la ley lipotecaria. Madrid, sincesores de Rivadeneyra, I $892-1890.0311 \%$

‘ Ramles, Rafacl. Lat prenda agricola ó hipoteca nobiliaria. Madrid, Rev. de legislation, 1910. 370 p. 
discussions of the mucultivated lands and waste lands-of which there is such an immense area in Spain-the lack of farm labor, its causes and effects, etc. Deficiencies in the civil code, so far as it trats of this subject, are exposed and criticized, and at tines foreign legistation is drawn upon for comparison.

$$
\begin{aligned}
& \text { COMAERCIA, IAIV } \\
& \text { COMMLRCII, CODL }
\end{aligned}
$$

HISTOKY

The need of a unitive and general connutreial law was inperative, as in civil law, but the realization of a commercial code anticipated that of the civil code. It has been said that Spain las the distinction of prolucing the first code of mercantile law in the work in her "Ordinances" of the seventeenth century, as in them is combined in the first single body" of law every nutter of mercantile law applicable to land and sea. The statute that really covered the entire Peninsula for the first time was the "Ordinances of Bilboa," I737, which atso spread to the Anerican colonies. This code renained in force in Mexico eren after its independence nntil the Mexican code of 1884 went into effect. The "Ordinances of Bilboa" was intended as a code for merchants especially.

The moders novenuent for codification resulted in the code of May 30,1829 , which went into effect on January i, is 30. This code was practically the work of one jurist, Pedro Sainz de Anclino, the secretary of the Commission appointed for its drafting. The neccssary reform of procechere in commercial causes was secured by the law of procedure of July 2,1830 . This and the law of December 10, 1831 creating the official exchange of Madrid and regulating contracts for public and commercial securities were also the work of Sainz de Andimo. the "anthor of Spanish commercial law," ats he is referred to in listory.

Before 868 the text of the code of commeree molerwent no alteration, although some of its provisions lad been repealed, and others modified, by laws of October $2 \$$ and November a, ${ }_{1} S_{37}$, relating to the purchase of foreign ships for a merchint marine, and to stock companies. Nevertheless, the trencundous industrial and commercial development of spain during the 
middle of the nineteentli century emphasized the necessity for many reforms in the code. By the laws of December 6, I868, and July $30, \mathrm{r} 874$, inportant changes were made. The code of commerce now in force was promulgated by royal decree of August 22, 1885, and cane into force on January 1, i 886. It was extended to Cuba and I'orto Rico on January 26, rss6, atid to the Philippines in isSS. The Mexican code of I $\$ 89$, too, is practically a reproduction.

The civil code snpplements the commercial code in commercial transactions, and in this connection it may be said that the most important provisions of the civil code are book IV, title I, obligations; title II, contracts; and title XVI, obligations not based upon agreement, or quasi-contracts. These sections of the civil code are translated in the "Commercial laws of the world" (infra, 65). Several important supplementary laws have been enacted separately, c. g. the decree of December 2 I, 1885 for the organization and government of the mercantile register; laws of March $18,1874, j u l y 14$, I S91, and May 13 , 1902 in regard to the Bank of Spain; the establishment of the Mortgage Bank of Spain (Dec. 2, 1872), and of chambers of commerce, industry and navigation (Apr. 9, I 856 ), amended materially June 31, 190 I, December 13, I901, Angust 30, 1902 and February 24, rgos; the law of maritime 1mortgage; the law of April 9, 1904 on compositions with creditors in prevention of bankruptey by companies which are concessionaires of public works; the establishment of clearing houses (Mar. 30, 1905); and several important insurance laws.

\section{CoNTENTS}

The Commercial Code contains general and special rules relating to mercantile traders, associations, commerce (inclinding maritime commerce), and all commercial transactions. There are other supplenentary statutes which must be consulted in many cases. The code is divided into four books embracing 27 titles and 955 articles.

Book one treats of commerce and commercial persons in general, and registry.

Book two deals with contracts which are essentially commercial in elaracter, including mercantile partnership and corporate agreements, their expiration and liquidation, contracts 
of banks, railways, and other jublic service companies, sales, loans, contracts for lant carriage, insurance, mercantile guarantees, and, finally, commercial paper.

Book three is devoted to maritime commerce, and contains elaborate provisions in regard to the law of shipping.

Book four contains provisions in regard to suspension of payment or insolvency, (a legal institution introduced by the code), bankruptey, and prescription or linitation of actions in commercial matters.

\section{GFNeRAL, I,ITERATtRE}

The commercial laws of Spain are included in the monumental series Handelsgesetze des Erdballs ${ }^{1}$ which is now being published in Finglish translation. This great undertaking, in which numerous eninent specialists of all nations have collaborated, is a compilation of the conmercial laws of the world in three editions or (ranslations, German, French and English. The work contains the commercial, bills of exchange, bankruptey and maritime laws of all eirilized nations, together with commentarics on ciril procedure, constitution of the courts, and trade customs in the original languages with translation. The Spanisl laws will be found in voltume V'II of the German edition (also reprinted separately), and in volume XXXIl of the American edition.

The commercial code as in force in Cuba, Porto Rico and the Plilippines, was translated into English by the War Department " in I 899 and was reprinted in the "Laws of Porto Rico" (supra, p. 48) in 1909. Attention may again be called to the fact that these translations by the War Department (being very literal) have in many instances proven defective

1 The conmereial laws of the world. Anerican ed. Consulting editor, Sir Thomas Fdward Scrutton ... general editor Willianı Bowstead . . with a general introduetion by Charles Henry Huberich .. Boston, Bostron Book Co., IgIt-13. $35 \mathrm{v}$. (in course of publication).

Same. German edition. Begrïnder des werkes: Dr. Oskar Borehardt. Berlin, R. v. Decker, I9II-Igr3. It r. (in course of publication).

2 The code of conmerce in foree in Cuba, Porto Rico, and the Philippines. Translation by the United States War Department. Washington, Government Printing Office, IS99. $29 \mathrm{I} \mathrm{p.}$

$7: \div: 1^{\circ}-15-5$ 
and inaccurate. The legislative history of the Spanish code of 1829 , with a brief description of its contents, appeared in the English periodical, the Law Magazine, volume 7 , pages $158-162$, a few years after its promulgation. Foucher ${ }^{1}$ translated the code of 1829 , with the relevant laws of procedure, into Frencli. The present code of 1885 was translated into Frencli by Hewri Prudhontne ${ }^{2}$ in 1891 . Some amendments to the code have since been enacted. Mr. José A. Espiritu has presented in volume 1, number I, of the Plillipine law journal, August, 1914 , pages $22-42$, a detailed ottline of the commercial code, indicating the parts of that code which are still in force in the Philippines, and those which have been repealed by subsequent legislation. The articles by title indicate brief concordances and include annotations of recent decisions handed down since the American occupation.

Hany editions of the code have been published. Besides the official editions of the Codes of $1829^{3}$ and of $1885^{4}$ and of the Code for the Philippine Islands and other foreign possessions, ${ }^{5}$ the Revista de los tribunales ${ }^{6}$ from time to time publishes private editions, which include the latest legislation and are annotated with the decisions of the Supreme Conrt. Nedina and Maranón's compilation of the civil laws of Spain (supra, p. 48) contains the commercial codes and related laws enacted tip to 1911 . Walton ${ }^{7}$ has published a collection of the

1 Code de commerce et loi de procédure sur les affaires et causes de commorce d'Espagne. Traduit par Victor Foncher. Rennes, Blin. I 838 . $580 \mathrm{p}$.

2 Code de conmerce cspagnol. Traduit et annoté par Henri Prudlomme. Paris, Durand et Pedone-Lauriel, 189i. 3.43 p.

${ }^{3}$ Córligo de comercio. Edición ofieial. Madrid, Real, i829. 335 p.

${ }^{4}$ Cólligo de comercio, edición oficial. Madrid, Ministerio de Gracia $y^{+}$ Justicia, $1885.466 \mathrm{p}$.

5 Cúdigo de comercio para las Islas Filipinos y demás archipiélagos españoles de oceania. Tid. oficial. Madrid, Ministcrio de Uitramar, I888. $299 \mathrm{p}$.

- Cúdigo de comerció con las últimas reformas . . concordado con las leyes civiles, etc. . . . anotado con la jurisprudencia. Por la redacción de la Revista de los tribunales. I2th ed. Madrid, Góngora, I910. $876 \mathrm{p}$.

7 Walton, Clifford S. Leyes comerciales y marítimas de la AnéricaLatina comparadas entre sí y con los códigos de España y las leyes de los listados Unidos de América. Washington, del Gobierno, 1907. 5 V. (Also Irondon, Hirselifield, I908. 5 v.) 
conmmercial and maritime laws of Latin-American countries, comparing them with the Spanish commercial code and the relevant laws of the United States. The Spanish code is user as the basis and the complete text, annotated with decisions of the Suprene Court, is set forth.

In addition to the general collections of court reports there is a valuable digest of the judicial decisions relating specifically to commercial law edited by Listasén." Three volumes have appeared, in which are digested the reports for the years 1838-1892, 1892-1902, 1902-1908. In 1911 Pastor $^{2}$ published a work on the commercial code annotated by the decisions of the Supreme Court. The compiler gives the reports under a plan desigued for rapid research. Barrio ${ }^{3}$ brought out in 1910 a collection of the decisions of the Supreme Court construing the commercial code.

The commentaries on the code, while numerous, are not so voluminous as those on the civil code. The editors of the Revista general de legislación ${ }^{4}$ published in 1886 a two volume commentary, the code being compared with foreign law. García Moreno ${ }^{5}$ has issued an edition of the code designed especially for the practicing lawyer (abogudo). A uscful work for students is that of Teófilo. ${ }^{6}$

'Estasén, Pedro. Repertorio de la jurisprudencia mercantil españolı ó compilación completa ... de las diversas reglas de jurisprudencia. . Barcelona, Penella y Boseh, 1894-1903. $2 \mathrm{v}$.

Same. Repertorio de la jurisprudencia y doctrina mereantil é industrial española ó compilación . . . en forma de prontuario. Madricl, Rev. de legislación, 19I I. 3I+1).

${ }^{2}$ Pastor y Bustos, I'. El código de comercio interpretado por la jurisprudencia del tribunal supremo. Madrid, Rev. de legislacion, 1911. 2 v. (Vol. 3 in publication.)

${ }^{3}$ Barrio y Morayto, L. Espíritu de la jurisprudencia españula. I a del códiga de comercio. Nadrid, "La Iïlitora," 19ro. $575 \mathrm{p}$.

4 Código de comercio de 1885 . Comentado y concordado ... por la redaeción de la Revista general de legislación. Madrid, Revo de legislación, 1886. $2 \mathrm{v}$.

${ }^{5}$ Garc ia Moreno, Alejo. Código de comercio de 1885 con las roformas hasta $1907 \mathrm{y}$ anotado con la doctrina de lus autores $y$ todas las sentencias del tribunal supremo. Madrid, Antonio Marzo, 1902. $577 \mathrm{l}$.

6 '́eúfilo y Doroteo . . . Código de comercio profusamente anotado y precedido de una breve reseña del movimiento meteantil á través de los siglos. Mardrid, J. Corrales, I902. $312 \mathrm{p}$. 
Among the treatises on commercial law, the "Instituciones" by Estasén ${ }^{1}$ is perhaps the most complete. The work conprises eight volumes and is divided into four main divisionshistory, legislation, special industrial law and theory. It is intended for teachers of law and students as well as for courts and practitioners. A work well recommended is the Curso or lectures on philosophical, historical and positive commercial law by Alvárez del Manzano. ${ }^{2}$ One of its two volumes appeared in a second edition in 1903 . This volume is general and is complete in itself. The atrthor's original intention to isste a larger work has been carried out by his participation in the publication of the projected sixteen volume work mentioned below. Another general work is the two volume treatise of Blanco Constans. ${ }^{3}$ The author does not confine himself to Spanish law but treats of the subject in general, including the legislation in other countries.

Three well known Spanish jurists, ${ }^{4}$ of whom Alvárez del Manzano is one, undertook in I gog to publish the commercial laws of Spain and the other nations of the world. The wlole project is intended to include sixteen volumes, in which the authors plan to cover every phase of the subject. Four volumes have appeared, volume I relating to merehants and commercial transactions, volume I I dealing witl mercantile registration, volume III with accounting, and volume IV with boards of trade and trade nanes. Volune $\mathrm{V}$, which will contain general discussions of commercial contracts, mercantile exchanges, stock exchanges, and factors, and volume VI, which will deal with mereantile companies or corporations,

1 Istasén, Pedro. Instituciones de derecho mereantil. 2d. ed. Madrid, Rcv, de legislación, I907. $8 \mathrm{v}$.

2 Alvárez del Manzano y Alvárez Rivera, Faustino. Curso de derecho mercantil filosófico, histórico y vigente (español y extranjero). Parte general. 2d. ed. Madrid, V. Suarez, r903. 87 i p.

3 Blanco y Constans, Francisco. Estudios elementales de derecho mereantil según la filosofia, la historia $y^{+}$la legislación positiva vigente en España y en las principales naciones de Europa y América. Mad. rid, Ia Sucesora de M. Minuesa de los Rios, Ig0I-I902. 2 v.

* Alvárez del Mlanzano y Alvárez Rivera, Fatstino; Bonilia y San Martin, Adolfo; and Miñana y Villagrasa, Emilio. Códigos de conercio espanoles y extranjeros . . . comentados, concordados y anotados ú estudios fundamentales de derecho mercantil universal. Madrid, $V$. Suarez, rgor-1914. $+\mathrm{v}$. (Others in cutrse of publication.) 
are announced for publication during 1914 . The completion of this undertaking, aside from its contribution to the world's legal literature, should $b e$ of great practical bencfit to all Spanish-speaking count ries.

A good handbook of Spanish commercial law is the numal of Benito, ${ }^{1}$ an anthority on the subject, and the anthor of the section on Spain in the "Commercial laws of the world" (supra, p. 65). The work includes one volume devoted entirely to int roductory remarks on commercial law which was published several years in advance of the handbook. Probably the most practical mannal on the subject appeared in 1913 from the pen of Miñana, ${ }^{2}$ one of the leading modern specialists in this branch of the law. This manual includes the code, supplementary laws, acts, decrees, ete, with annotations.

A brief treatise on Spanisl and international commercial law was written by Carreras and González Revilla, ${ }^{3}$ the seventl edition of which appeared in 1910. Gual Villalbi's ${ }^{4}$ recent (19r3) treatise on international commercial law coters the conflict of laws.

MERCANTILE REGISTER.-A mercantile register for individual merchants and companies exists in Spain. It is obligatory for companies and ressels, and practically for merclants in general, to register. Sections $16-32$ of the commercial code contain the general rules. The regulations for the organization and govermment of the mercantile register were approved by royal decree December 21, 1985. An official edition ${ }^{5}$ of the stat ist ies of the Register, compiled by the general director, appeared in 1902 .

ACTS OF COMMERCE.-Book one goes into much detail concerning acts of commerce, but title IV, section 54, provides

1 Benito y Endara, Lotenzo. Manual de derecho mercantil. Valencia, Domenech, 1904-1908. $3 \mathrm{v}$.

2 Miñana y Villagrasa, Enilio. Código de comercio. Madrid, Hijos de Reus, 1913. I, $166 \mathrm{p}$.

${ }^{3}$ Carreras y González, Mariano and González Revilla, I,copoldo. Derecho mercantil de España $y$ derecho mercantil internacional. ;th ed. Madrid, los Sucesores de Hernando, rgro. $550 \mathrm{p}$.

${ }^{4}$ Gual y Villalbi, Pedro. Tratado de derecho nercantil internacional. Madrid, A. Narzo, I913. $616 \mathrm{p}$.

${ }^{5}$ Estadistica del registro mercantil formada por la dirección general de los registros. . . Ed. oficial. Madrid, Succsores de Rivadeneyra, I $90 \mathrm{I}$. I $20 \mathrm{p}$. 
that in all instances where there is no express provision in the code the common law governs. Zurita Nieto ${ }^{1}$ has given, in the first volume of his studies of comparative mercantile legislation, a discussion of mercantile contracts and merchants in general. Lastres ${ }^{2}$ has likewise published a brief monograph on conmercial transactions. The laws for commercial agents such as factors, brokers and traveling salesmen have been discussed by Benito ${ }^{3}$ in a short article on mercantile agency, published separately, and by Estasén ${ }^{4}$ in a special work.

The law governing the account current, the contract itself and its effect, is well covered in two treatises on the subject, one by Vallés ${ }^{5}$ of Barcelona, and the other by Estasén ${ }^{6}$ who cites all the decisions of the Supreme Court in point.

STOCK EXCHANGES

The bolsas de comercio or the commercial exchanges are the legally authorized public establishments in which merchants and intermediary agents enter certain kinds of cont racts. The code, in sections $64-80$, authorizes the creation or establishment of these bolsas in cities where they are needed, enumerates the the contracts to be entered into on the exchanges and provides regulations for the conduct of business. It is necessary, however, to consult the reglamento or decree for the regulation of the stoek exchanges enacted December 31,1885 , to which a few amendments liave been made. A market-overt law prevails also for sales in public places and shops. The irrevocability of the draft payable to bearer used in the exchange in cases of theft, robbery or loss is interestingly discussed in

1 Zurita Nieto, Benito. Ios actos de comercio considerados en si mismos y en relación con los comerciantes. (Estudios de legislación mercantil comparada tomo $1^{\circ}$ ). Madrid, "Fl trabajo," I899. I5I P.

${ }^{2}$ Lastres, Francisco. Los actos de comercio y la jurisdieción mercantil. Madrid, M. G. Hernandez, I888. 20 p.

3 Benito y Eindara, Lorcnzo. El mandato mercantil. Barcelona, "Fl viajante," Igo4. Pamplilet.

"Estasén, Pedro. El viajante y el representante de comercio según el derecho español. Barcelona, "Eil viajante," igo4. I v.

"Vallés y Pujals, José. Eil contrato de la cuenta corrienta. Barcelona, Guinart y Pujolar, 1906. 308 p.

${ }^{8}$ Estasén, Pedro. De las cuentas corrientes y de los contratos de cuentas corrientes según el derecho español. Madrid, Hijos de Reus, 1910. 2 II $P$. 
the work of Maluquer, annotated with the decisions of the Suprene Conrt. Many works have been published on the law governing the operation of the bolsas and related questions. Capdeville ${ }^{2}$ in his work covers reliably the practical operation of the "bolsa" as employed in Spain and elsewhere, especially. in Madrid, Paris, and Brussels. He includes a glossary of the principal words or terms used on the exchange. The eminent specialist I.ast res ${ }^{3}$ has published a work on the operations on the exchange with special reference to the public secnrities of brokers and other agents. A new (19I4) edition is now in preparation. A listory of the bolsa is included in the older brief treatise of MIontero ${ }^{4}$ covering, in addition, commerce in general and mereantile companies.

BANKING LAW

General provisions for the regulation of banking transactions are found under section 175 et seq. of the code. The banking system of Spain is based on a national bank, the Banco de España, established by royal decree of March i9, 1874. This is the only bank of issue that exists in the nation. This powerful institution is governed by the royal decree that established it; by the law of July 14,1891 ; by the law of May 13, 1902, and by its constitution and by-laws approved by royal decree of Dec. Io, 1900, and Jan. 5, 1901. Several collections $^{5}$ of the laws and statntes governing the National Bank have been published from time to time, the latest in 1914. A special edition of the review "Vida Economica,"

${ }^{1}$ Maluquer $y$ Viladot, Juan. Irreivindicación de cfectos al portador en los casos de robo, hurto o extravio. Estudio sobre las bolsas de comercio y sus agentes mediadores. Anotado con 1a jurisprudencia ... prólogo de Antonio Maura. Barcelona, Henrich y Ca., Inor. $2.38 \mathrm{p}$.

2 Capdeville, Edmundo. La bolsa al aleance de todos. Las operaciones en las bolsas de Madrid, Paris, Bruselas. Madrid, Nacional $y$ Extranjera, I905. $198 \mathrm{p:}$

${ }^{3}$ Lastres, Francisco. Operaciones de bolsa. Contratación solbre efectos públicos de los corredores de comercio ye de los agentes de holsa. Madrid, V. Suare, is 8 S. $344 \mathrm{p}$.

${ }^{4}$ Hontero y Vidal, José. La bolsa, el comercio, y los sociedacles mercantiles. 3 d ed. Madrid, Huérfanos de la Sagrada Corazón de Jesís. $\mathrm{I}^{8} 8_{3} .262 \mathrm{p}$.

${ }^{5}$ Banco nacional de Iispaña. L,eyes, estatutos y reglamento. Madrid, Bernardo Rodrignez, igri. 167 p. Suppl. I9I4. 
volume 3 (32 pages), published in April, 1914 , gives the liistory of the National Bank of Spain, texts of relevant laws, and some statistics. A general work on the question of money and bills of exchange was published by Gil ${ }^{1}$ in 1906.

The code contains in articles 2 1 2-217 special rules for agricultural banks and societies. Noguer ${ }^{2}$ has recently (I9I2) published a practical work on the agricultural cooperative credit associations in Spain, including sections devoted to historical and theoretical discussions. The author also discusses foreign institutions of a similar nature. Ramos, ${ }^{3}$ in 1903 , issucd a treatise on agricultural credit or loans. The work includes discussions of credit societies, the relevant provisions in the commercial code, the mortgage bank, etc.

Credit and loan associations dealing with mortgages on real estate were scarce in Spain prior to 1872 . Although their legal existence was recognized by royal decree of Jannary 5,1869 , the few established up to 1872 were more or less unsafe. To remedy the situation the law of December 2, 1872 , was enacted, wlich establislied the Banco hipotecario español or the Mortgage Bank of Spain. This bank enjoys some exclusive privileges and its cliarter extends for ninety-nine years. The law creating it contains thirty-eight articles providing specific rules for the carrying out of its purposes.

The establislinient of cleariug houses at Madrid and Barcelona was authorized by royal decree of March 30,1905 .

COMMERCLAL ASSOCLATIONS

The various kinds of corporations and associations of nat 1 ral persons for business purposes are dealt with in book II of the commercial code. Section 122 enumerates the three general forms recognized by Spanish law: (I) The ordinary unlimited partnership (la compania colcctiva); (2) the limited form (compañia cn comandita) in which one or more persons bring fixed capital into the conmon fund, to abide by the results of the partnership operations, directed exclusively by

${ }^{1}$ Gil y Pablos, F. Estudios sobre la moneda y los cambios. Madrid, Rev, de legislaeión, $1906.38_{3} \mathrm{p}$.

2Nogucr, Marciso. Las cajas rurales in España y en el extranjero. Madrid. Administración de Razón y Fe, rgr2. 668 p.

${ }^{3}$ Ramos, Rafael. Eil crédito agrícolo. (Cajas rurales de préstamos.) Madrid, Hijos de Reus, 1903. 2 v. 
others in the collective name; (3) the limited form or stock company (compañia anónima) which corresponds to our "corporation."

The compania on comandita is in principle the prototype of the limited partnership, tmknown to the common law, but now recognized by statute in most of our states. It is similar to the Kommanditgesellschaft in German law or the "commandite" company of ot her European countries. It is neither a partnership nor an ordinary stock corporation, as some of the members are liable to creditors to the amount of their shares only and have no voice in the management, whereas the others, the partners, who have exclusive control of the operation of the business, are liable in solido as menbers of an ordinary partnership.

Benito ${ }^{1}$ in 1904 prepared a brief lecture or conferencia on the different forms which mercantile associations may adopt. A more complete treatise on the subject, including private banks and the national bank, was published in 1907 by Estasén. ${ }^{2}$

RAILROADS AND PUBLIC SERVTCE COMPANIES.

The business of carriers and the conveyance of goods and persons by land is largely regulated by sections 349-379 of the commercial code. Sections $184-192$ deal with the organization and financial managenent of railroads and public service companies. The carriage of postal, telegraphic or telephonic correspondence, of declared valuables and of merchandise in postal packets is not mercantile according to the Spanish law, because it constitutes a public service monopolized by the State, the working whereof may be assigned to individuals under certain conditions. These are regulated by numerous statutes enacted from time to time as the service demands.

The important special laws for railways are: the general law of November 23, $1 S_{77}$; the railroad police regulation of the same date; the regulations for the application of both laws dated Nay 24 and September 8, I $_{7} 8$ S. This railroad police

1 Benito y Endara, Lorenzo. Formas que pueden adoptar las sociedades mercantiles. Madrid, Rev, de legislación, I90.4. 24 1).

2 Fistasén, Pedro. Tratado de las sociedades mereantiles y demás cntidades de carácter comercial según el dereclıo español. Madrid, Hijus de Reus, 1907. 613 p. 
regulation is an extensive law and goes into ninute details as to the regulations for the deportment of passengers, tickets, bills of lading, running of trains, etc. The latest important railroad law was passed on Mlarch 26, 1908 , on secondary railways, followed by the reglamento for its application Jan. I4, 1909. Translations have been made by the United States War Department of the railroad law and the railroad police regulation as extended to Cuba, ${ }^{1}$ Porto Rico ${ }^{2}$ and the Philippines. ${ }^{3}$

There are sereral collections of railway legislation, often combined with treatises on the subject. The most convenient and complete collection of the railway legislation, including that of street railways, is the work of Mouton ${ }^{4}$ published in 1908. This contains the general law of 1877 , the police regulation, all the statutes to 1908 , and the relevant sections of the code of commerce, etc. Each section is annotated with the court decisions in point. The work of Torino ${ }^{5}$ on the railroad legislation, which appeared in 1902 , also includes strect railways (tranvias).

An extensive encyclopedia of the legislation and also of the practical administration of railroads in their legal, technical, administrative, and conmercial aspects, the latest edition bearing date $\mathrm{J}_{\mathrm{S}} \mathrm{S}_{2}$, was compiled by Garcés ${ }^{5}$ with the collab-

Translation of the law of railroads for the island of $C_{11 b a}$ and regulations for its execution with additions to date (I895). By U.S. War Dept., Washington, Govemment Printing Office, IS99. $5^{8} \mathrm{p}$.

2 Translation of the law of railroads for the island of Porto Rico. Same, Washington, Government Printing Office, 1 \$99. 45 p.

Same. Police law of railroads and regulations for its application promulgated Fcb. 17, I888. Washington, Government Printing Office, 1899. $37 \mathrm{p}$.

3 Translation of railroad laws and regulations for the Philippine Islands ... to Aug. 1900. Washington, Government Printing Office, 1900. 7 I p.

Same. Regulation for the execution of the police law of railroads. Washington, Government Printing Office, I899. 27 p.

4 Moutón y Ocampo, Iuis. Doctrina, legislación y jurisprudencia sobre ferrocarriles $y$ tranvias . . comentadas, concordadas $y$ anotadas. Madrid, Rev. de legislación, r $908.559 \mathrm{p}$.

s Torino, José. Legislación de ferrocarriles y tranvías. Concessión y construcción. Madrid, Hijos de J. A. García, 1902. 96I p.

${ }^{6}$ Garcés, Benito Vicente. Diccionario razonado, lcgislativo y práctico de los ferrocarrilcs españoles bajo el especto legal técnico, administrativo y comcrcial de los mismos con la colaboración de José Gonzàlez Alvarez. 2d cd. Machid, Indicador de los Caninos de Hierro, I875-IS82. $4 \mathrm{v}$. 
oration of González Alvarez. A smaller work of similar nature is the Diccionario of González de las Cnevas and Sastre ' publisled a few years later. A complete treatise or railway and strect railway law decisions has been published by Foye.? The body of the work, in five volunes, was published between 1894 and 1904 , and six appendices carry the work through 1910. The organization of railroad companies and their legal character, together with their relations with employees, are treated of in a work by Martin-Gamero. ${ }^{3}$

A mannal dealing with the contract of transportation was published by Foyé ${ }^{4}$ in 1886 . Bravo Moltó ${ }^{5}$ in 1891 produced a two volume treatise on the legislation of communication and transportation in general. The laws governing the mail are discussed in a work by Gutiérrez. ${ }^{6}$ A history by Verdegay ${ }^{7}$ of the corrco (post) from its origin, with an appendix of legislation of the countries which form the universal postal union, appeared in $\mathrm{x} 89.4$.

\section{INSURANCE}

The commercial code, in sections $380-43 \mathrm{~S}$, deals fully with the contract of insurance, including life, fire, land transportation, and other kinds of risks. On May 14, 1908, a law was passed for the registration and control of insurance companies. This law has four main titles and some additional

' González de las Cuevas, José and Sastre y Rodríguez, F'. Diccionario gencral de ferrocarriles. Públicado bajo la dirección de Fernández del Rincón. Madrid, Minuesa, $188 \%$. $7+7 \mathrm{p}$.

${ }^{2}$ Foyé, R. Los caminos de hierra de España. Recopilación ordenada de las disposiciones legales vigentes . . construcción y explotación, legislación y jurisprudencia. Barcelona, Tasso, 1894-1904. $5 \mathrm{v}$. (6 app. to Igi I)

${ }^{3}$ Martin-Gamero, Andrés. Constitución y organización de las compañas de ferrocarriles $y$ carácter jurídico, condiciones y relaciones de sus empleados. Madrid, los Ferrocarriles, isgr. $306 \mathrm{p}$.

${ }^{4}$ Foyé, R. Manuel del contrato de transporte. Barcelona, Taso, I886. $368 \mathrm{p}$.

${ }^{5}$ Bravo Mloltó, Iimilio. Legislación de comunicaciones. Mladrid, Núíiez, I89r. 2 \%.

"Gutiérrez, Francisco de Asis. Legislación de correos. Madrid, Cuesta, I893. $2 \mathrm{I} 4 \mathrm{p}$.

Same. Madrid, Ambrosio Pérez y Ca., I902. 207 P.

- Verdegay y Fiscowich, Eduardo. Historia del corrco . . . con un apendice que comprende la legislación interior de los paises que forman la unión postal universal. Madrid, Ricardo Rojas, 1894.475 1'. 
provisions for its application, divided as follows: I, General provisions; II, Publicity and guarantees: III, Advisory board and inspection of insurances: $I V$, Liabilities. A provisional reglamento was promulgated by royal decree July 26, 1908 and it was not until February 2, 1912 that a final or definite regulation (reglamento definitivo) appeared. This reglamento contains 187 sections. The Ilustracion financiera ${ }^{1}$ has printed an edition of the Reglamento definitivo de seguros in a small pamphlet of 129 pages. There appear to be very few Spanish treatises on insurance; the works of French and other foreign authors are used to a great extent. Estasén, ${ }^{2}$ in 1906, published a small but good general work on all branches of insurance law.

The Workmen's Compensation Act of January 30, 1900, in article 12, authorized employers to transfer their liabilities to injured employees to insurance companies conforming to certain requirements. Companies insuring against risks of accidents to workmen sprang into existence. The royal decrec of August 27, 1900 relating to these companies and the reglamento of the Workmen's Compensation Act of July 28 , 1900 contain the laws governing this branch of insurance.

BILLS AND NOTES

A complete negotiable instrunlents law is given in the code in sections 4.3-566. The leading treatise on the subject is the work of Huguet, ${ }^{3}$ a second edition of which appeared in 1910 . The bill of exchange is especially emphasized, but all forms of negotiable paper are included in the work. Benito ${ }^{4}$ published a brief monograph on the subject in 1906.

The aral in Spanish law constitutes a document similar to our anomalous indorsement, although it may also be made

${ }^{1}$ Reglamento definitivo de seguros para aplicación de la ley de i4 de mayo de igos . . públicado por r. d. de 2 de febrero de igiz. Madrid, Ilustración financiera, I9I2. $129 \mathrm{p}$.

${ }^{2}$ Estasén, Pedro. Los seguros. ad ed. Barcelona, F. Granda y Ca., I $906.300 \mathrm{p}$.

${ }^{3}$ Huguet y Compañá, Pedro. La letra de cambio y demás documentos mercantiles... 2d ed. Barcelona, Sucesores de Manuel Soler, Igro. $527 \mathrm{p}$.

${ }^{4}$ Benito, Lorenzo. La letra de cambio. Figureas, Mariano Alegret, 1906. I7 P. 
restrictive. Estasén ${ }^{1}$ in 1902 publishcd an article on this form of commercial transaction.

the eleque or bank cheek has received individual treat ment in the work of Nlora" published in Havana. 'This book, which is a prize essay, gives the law of foreign countries as well as of Spain.

MARITIME LAW

Book III of the code deals with maritime commerce, and the whole subject, except the maritine mortgage (hifoted nazal), is practically covered. The "Regulation for merchant navigation" promulgated by the Ministry of Marine and approved by royal order of January $1,188_{5}$, is still in force in regard to the physical management of ressels. It is a police regulation.

Title I deals with the ressel and its parts and the sale thereof, voluntarily, by necessity, or judicially. Title II covers the regulations and laws governing all persons who take part in maritime commerce as owners, masters, officers and crew, and stupercargoes. Special contracts, e. g., afireightment, bottomry and insurance are treated of in title IlI The risks, damages and accidents of maritime connmerce including average, calls at a port of refuge, collisions, shipwrecks, etc., are inciucled in title $I V$. Title $V$ deals with the proof and adjustnent of average, both general and particular.

The naritime laws of Spain have been translated into English by F. W. Raikes ${ }^{3}$ of 1 ondon. The work is annotated and includes a translation also of the law of maritime mortgage. The Spanish commercial maritime law has been discussed briefly in French and compared with the law of other continental countries by two writers, Jacobs and Ouwerx."

In 1888 , Agacinio ${ }^{5}$ published an encyclopedia of the maritime legislationf from is 85 to 1888 . The first volume of an ency-

1 Escasén, Pedro. Lil aval. Fisayo juridico. Barcelona, F. Cranada y Ca., 1902. 4\$p.

${ }^{2}$ Mora, Federico. Del cheque. Habana, Gobierna y Capitania general, I88. I95 p.

${ }^{3}$ Raikes, 1 . IV. The maritime codes of Spain and Portugal. Translation. Iondon, Iiffingham Wilson, $1890.212 \mathrm{p}$.

* Jacobs, Victor and Ouwerx, Lambert. La loi espagnole relative an commerce maritime. Bruxelles, F. Larcicr, $1886 .{ }_{13} \mathrm{~S}$,

${ }^{5}$ Agacinio y Martínez, Eugenio. Diceionario de la legislación marítima. Contierie en extracto las disposiciones vigentes.. desde is $54^{-}$ 1888. Madrid, Mnfanterial de Marina, I888. 505 13. 
clopedia of maritime law including all the legislation, decrees, etc., arranged in alphabetical order, was published in 1908 by Parreño." A good treatise on maritime law is the production of Godinez. ${ }^{2}$ A sliort treatise on towage (remolque), assistance and salvage was published in $191 \mathbf{1}$ by Estasén, ${ }^{3}$ the anthor of numerous works on commercial law. In this work he includes the conventions of the intermational conferences of maritime law at Brussels in 1905 and in 1910.

A mannal of the legislation on the merchant marine, by Ruiz, ${ }^{4}$ appeared in 1904 . The question of marine jurisdiction and the laws applicable to the adniralty courts are discussed in a treatise by Moreno. ${ }^{5}$ A manual of the admiralty courts was published by González Naroto and Tapia "in I 903.

The n1aritime mortgage, hipoteca naval, is dealt with in a special statute. It has always been treated as distinct from the mortgage of other kinds of property. In 1888 , five years before the present statute, Gongález Rerilla ' published a work on the subject, treating comparatively the legislation of other countries. The same author, immediately after the passage of the law of August 21, 1893, issued a convenient manual ${ }^{8}$ of the Spanish law, comparing it with foreign law. The treatise of Ayllon ${ }^{9}$ on commerce and the naval mortgage

${ }^{1}$ Parreño y López, García. Diecionario de derecho maritimo. Cartagena, Soe. Le vantina de úrtes gráficas, igos. v. I (A-C). 76I, 31 p.

${ }^{2}$ Godinez y Mihura, Manuel. Flementos de derecho marítimo español. Madrid, Infanteria de Marina, $1392.73+1$.

3 Estasén, Pedro. Cuestiones de derecho marítino. Rennolque, asistencia y salvamento. Madrid, Hijos de Reus, 19 II. 24 I p.

* Ruiz y Gil, Cristobal. Manual de legislaeión del marino mercante. Madris, Miguel Diaz, 1904. 235 p.

s Moreno y Lorenzo, Joaquin. La jurisdiceión de marina. Tratado de todas las leyes, etc. de constante aplicación en los tribunales de miarinı. Madrid, Hijos de F. A. Gareia, is 895 . I016 p.

"González Maroto, Fernando, and Tapia y Casanovas, José. Mannal de los tribunales de marina. Madrid, Ministerio de Marina, I903, 5361 1.

־ González Revilla. Leopoldo. La hipoteca naval en Iispaña. Tistudio de legislación mercantil comparada. Madrid, Infantería de Marina, Is9s. 420 ].

¿González Revilla, Leopoldo. Manual práetieo de la hipoteca naval, comentarios y texto de la ley de ar de agosto de is93. Madrid, Góngora, I39٪. $3+4 \mathrm{P}$.

"Ayllon y Altolaguirre, linilio. Fil eomercio y la hipoteea naval. Madrid, Rojas, I893. I v. 
also warrants mention. A work relating to the maritime broker which contains the legisktion, but is otherwise not very useful, was published in 191.3 by Arriaga. ${ }^{1}$ i highly rcommended treatise on intermational maratime law by Negrin (infra. v. 133) appeared in a scond cdition in 1858.

CONST T.1R I..IW

Consular legislation bears a close relation to maritime law, as consuls in foreign ports where spanish vessels arrive are representatives of the Spanish State for all the purposes of the application of the laws which relate more or less directly to commerce and navigation, an exterritorial privilege which is both granted and limited by treatics. It is, therefore, proper to give an indication of the laws by which the consular body is controlled in these matters. The subject is now gotcrned by the organic law promulgated by royal decree April 27, 1900. Which was completed by the law of September I, 1906. The consular jurisdiction is regulated by the decrec of September 29, IS48. In addition to these there are provisions in the commercial and civil codes and many decrees and orders of lesser importance. The most recent and useful work on the subject is that by Mahtutuer ${ }^{2}$ which, with two appendices, brings the law down to 1908 . A third eppendix is now (1914) in course of publication.

B.NKRUPTCE

The Spanish law of suspension of payment and bankruptey is given in book four, title $I$, of the commescial code, as amended by the law of June 10,1 S97. This law drafted anew sections $870-873$, inclusive, on suspension of payment, or insolveney, and its effects. The divisions or sections of the code cover: I, suspension of payment and its effects;II, general bankruptey provisions;-III, the kinds of bankruptey and the rules governing creditors and persons colluding or aiding in fraudulent hankruptcies;- $-\mathrm{IV}$, composition of bankrupts with their creditors; - $V$, rights of crelitors and their clasification;-VI, discharge of the bankrupt;-VII. general provisions relating to the binkruptey of mercantike

'Arriaga, Emitiano de. lil libro de la correduria maritima, Billom. Lerchundi, I9I3. $360 \mathrm{p}$.

2 Maluquer y Salvactor, Mignet. Derecho consular esponol. Mactriu, Hijos de Reus, igos. 900 '. and 2 app. 
societies in general;-VIII, suspension of payment, bankruptcies of companies, and undertakings for railroads and other public works. The arrangements with creditors by companies which are concessionaires of public works are governed by the law of April 9, 1904.

It is important to notice that suspension of payment is a legal institution distinct from bankruptcy. It was first established by the commercial code. A solvent merchant who is in possession of sufficient assets to meet all his debts, but foresees the impossibility of doing so on their respective due dates, may place himself in a state of "suspension of paynent " on regular application. Thus a merchant is allowed to satisfy his debts before the danger of being thrown into bankruptcy confronts hinn.

The rules of procedure in bankruptcy matters are included in sections I $318-1396$ of the code of civil procedure. In the volume on Spain of the "Commercial laws of the world" (supra, p. 65), American edition, these rules are elaborated and explained (pp. $71-83$ ). In the case of suspensions of paytnent, there are 110 special rules of procedure either in the code of civil procedure of 1881 or in any other law, except that which relates to the arrangenent with the creditors of the bankrupt. Thus it is that procedure in these matters is governed by what the judges in the trial and appellate courts determine in each case in accordance with their knowledge and understanding. In sections $870-873$ a "special " law for procedure in suspension cases is referred to, but no such law has yet been enacted.

There are several good works dealing with the subject of bankruptey. The treatise of Estasén ${ }^{1}$ contaius a valuable historical introduction of $13^{6}$ pages and also a bibliography of Spanislı and foreign works dealing exclusively with suspension of payment and bankruptcy. The second edition carries the work to 1909 . Another work to be recommended is the commentary of Nogus and Martorel1 ${ }^{2}$ on book four of the

1 Jistasén, Pedro. Tratado de las suspensiones de pagos y de las quiebras. Estudio teórico-práetico ... ad ed. Madrid, Hijos de Reus, I9og. 670 p.

- Nogués, Emilio José Naría, and Martorell y Rovira de Casellas, Luis. Ouiebras y suspensiones de pagos. Comentarios al libro del código de comercio concordado y comparado . . legislación ... de Europa. zol ed. corr. con arr. ála ley de io de juniode i897. Madrid, Ja Propaganda universal, i897. 605 p. 
code of commerce. It is a practical survey of the entire Spanish law on the subject and draws comparisons with the laws of other linropean countries. A wo rolume work on the theory and practice of the law governing the meeting of ereditors and hankruptey was produced in $190+$ by Rives, ${ }^{1}$ with an introduction by Manresa. I handbook of procedure in bankruptcy, covering other nations as well as Spain, was published in 1898 by Redondo. ${ }^{2}$

Some of the provisions in the code of conmeree, especially in regard to suspension of payment, proved highly unsatisfactory. This caused numerous criticisms until the law of June 10, r897, made several anendments. A commission, previous to 1897 , had been nianed by the National Commercial Congress for the purpose of revising the above sections of the code. The dictamen presented by: Lastres ${ }^{3}$ before the Commission in $r 89.3$ is of interest in the study of this branch of the subject.

LIMITATION OI ACTIONS

Linutations of actions or prescripciones for contracts and clains, both $\epsilon x$ delicto and ex contratu, arising in mercantile transactions, are set forth in articles $942-955$, under two titles of book four.

COMMERCIA, COURTS

P'rior to 1829 commercial canses were generally heard hefore consuls and not in the regular civil courts. By the corle of 1829 the consular jurisdietion disappeared and was replaced by the Tribunals of Commerce (likewise conuposed of consuls) which had to try nercantile causes as provided in article $117^{8}$ of the code. Where there was no Tribunal of Commerce the mereantile jurisdiction was entrusted to ordinary juelges.

${ }^{1}$ Rives y Martí, Francisco de P. Teorial y práctica de actuaciones judiciales en materia de concurso de acreedores y quicbras, con sus preliminares quita $y$ esperay suspensión de pagos. $2 \mathrm{~d}$ ed. Madrid, Fortanet, ro04. $2 \mathrm{v}$.

${ }^{2}$ Redondo, Remigio Antón. Quiebras. Manual sobre el precedimiento en los juicios universales de quiebras. Madrid, Sneesores de Alba, I896. I 41 p. (with charts and forms.)

${ }^{3}$ Lastres, Francisco. Dictamen de la comisión nombrada por el congreso para informar la proposición de ley relativa á suspensión de pagos y quiebras presentada por . . Madrid, Hijos de J. A. García, I893. $40 \mathrm{p}$.

$$
77291^{\circ}-15-66
$$


By royal decree of February 7, I831, commercial courts were established at all the important cities of the Peninsula. These new courts did not give the results expected of them and many abuses were committed under their rule. They were abolished by the law of Decenber 6-8, i 868 . From that date there has been no difference between the ordinary and commercial jurisdiction in Spain, except in certain provisions of the law of procedure applying only to mercantile questions. Their reestablishment, however, is a live question at present. Lorenzo Benito,' in an article published in I 905 , asserts that the agitation in their favor is merely a protest against the defects in the adnunistration of justice which are felt quickly when they affect mercantile interests. Gómez Chaix ${ }^{2}$ in 1892 published some notes or apuntes on the comnercial conrts and their establishment in Spain. The reestablishment of the courts lias been debated considerably in the National Commercial Congress, a private organization. Arguments on both sides are printed in the reports of the congresses ${ }^{3}$ of is $89 \mathbf{r}$ and is86, and of the Congreso juritico español of 1886.

CHAMRERS OF CUMMERCE,

On the initiative of Eduardo Perez Pujol, a professor in the University of Valencia, there was created in Spain by royal decree of April 9, I886, an institution ealled "Chan1bers (Cámaras) of commerce, industry and navigation." This institution is a permanent organization with separate associations in the different cities, and in foreign ports where there are a sufficient number of Spaniards engaged in mercantile pursuits to warrant them. Its purpose is to recommend, or petition for, changes in the laws, encourage commerce, settle labor disputes when chosen as arbitrators, ete. The

1 Benito, Lorenzo. Los tribunales de comercio. Barcelona, "El viajante," I905. $32 \mathrm{p}$.

${ }^{2}$ Gómez Chaix, Pedro. Apuntes acerea de los tribunales de comercio y st1 establecimiento en España. Malaga, Poeh y Creixell, IS92. $148 \mathrm{p}$.

${ }^{3}$ Actas del congreso nacional mercantil de noviembre-dieiembre de I88I. Tema 2d. Madrid, El porvenir liberario, i882. 38I 1'.

Same. De mayo de I 886 Tema $5^{\circ}$ and I 882 Madrid, El porvenir liberario, 1887 . I $v$.

"Actas del congreso jurídico español de is86. Tema I2th. Madrid, El porvenir liberario, isso. I $v$. 
"Chambers" by law numst necessarily be consulted on proposed treaties, the regulation of rates, public labor contracts and on reforms of the code of commeree and mereantile procedure. It is in the nature of a board of trade with some of the powers of onr Interstate Commerce Commission. The laws which now regulate the Chambers of Connerce are the act of June 29, 1911, and the decree of December 29, 191 . For a discussion of these camaras a brief monograph or lecture by Benito, ${ }^{1}$ published in 1 Sgy, is suggested.

COMMERCIAI, TREATIES

Treaties have little effect upon the commercial rights of foreigners because, by virtue of the provisions of article it of the present commercial cole, foreigners in Spain may carry on commerce like subjects themselves, without any special linitations or conditions. Besides this, Spain has given her arlherence to the Universal Conventions on Posts, Telegraphs and the Protection of Trade Narks and Patents. The modem commercial treaties of Spain may be fonnd in the extensive collection of Spanish treaties by Olivart (infra, p. 130). The commercial treaties concluded between the United States and Spain prior to $189 S$ were replaced by the general treaty of July 3, Igor (Malloy's Treaties, I910, II, 1701).

\section{CIVIL, PROCEDURE}

CODE OF CIVII, PROCEDURE.

Civil procedure in Spain is groverned by the act or code of civil procedure (ley de enjuiciamiento ciril) of February 3 , I88I, with some amendments, and the judiciary act (loy orgánica sobre el poder judicial) of September 15, IS7o, with its supplementary law of October I 4 , ISS2. Until i $S_{55}$ civil procedure, except in minor cases, was practically governed by the Partidas and the Norisima recopilacion. The constitution of $1 S_{12}$ in article 12 brought about some reforms, and a few inportant statutes were later enacted, notably, the provisional regulation for the adninistration of justice on Septenber $26,18_{35}$, and the law in regard to the courts of first instance on May 1, is $S_{4}$. The first ciril procednre act was adopted October 5,1955 , and was extended to Cuba

${ }^{1}$ Benito, Lorenzo. Las cámaras de comercio. Madrid, Rev. de legislación, I899. Pamphlet. 
and Porto Rico, December 9, I865. The act of 1855 was completely revised and in the form of the present act or code was again promulgated February 3, IS8I. An important amendment was enacted May I I, I 888 , and others have followed from time to time. The code of r88r, considerably modified, was extended to Cuba and Porto Rico, September 25, I885, and a law almost identical with the Cuban law was extended to the Philippines, February 3, I888.

Procedure in commercial cases is governed by the code of civil procedure since the abolition of the commercial courts in r868. Oniy in the voluntary or noncontentious jurisdiction are there special provisions for procedure in commercial matters. There is no separate procedural statute for bankruptcy, as the code fully covers the subject. A statute bearing a close relation to the code of civil procedure is the law of Norember 12, 1 $\$ 69$, modified by the law of April 9, rgo4, on insolvency and foreclosure proceedings against railway and other public service companies. The act of December $4,188,3$, amended by royal decree January 7 , r8s, regulating costs in courts of justice and notarial fees (aranceles judiciales y notariales), may be noted.

The code of civil procedure, having been enacted before the present eivil code was adopted, contains in some instances conflicting provisions, and in others lacks the corresponcling provisions of the civil code, as in the case of the family conncil. In form it is complicated and somewhat longer than the civil code. It is arranged in three books, which together contain 2,182 articles. Spanish civil procedure is divided into two divisions or jurisdictions, according to the general nature of the action, contentious (contenciosa) and voluntary or noncontentious (ioluntaria). Book I contains provisions concerning jurisdiction and procedure common to all cases. Book II covers the contentious juriscliction which is employed in actual controversial litigation. Title $\mathrm{V}$ of book II provides for a unique arbitration of civil suits out of court (juicios arbitral $y$ de amigables componedores), a Spanish institution which has proven eminently successful. Book 111, which is devoted to voluntary jurisdiction, is divided into two parts. Part one covers civil cases in general, and part two commercial cases. Voluntary jurisdiction, which corresponds to the noncontentious jurisdiction of Germany, 
France and other linropean conntries, is employed when, without any contest between the parties, judicial intervention is necessary for the official legal authentication of certain acts, e. g., acts in the nature of ex parte proceedings, as those for adoption, appointment of guardian, adninistration of estates, cte.

\section{GENERAL L,ITERATURE}

There is no English translation of the Spanish code of civil procedure, but the cole of Cuba and Porto Rico was translated by the War Department ${ }^{1}$ in 1901 and reprinted in Iaws of Porto Rico (supra, p. +8 ). Convenient editions of the Spanish code are published by the Revista de los tribunales. ${ }^{2}$ The eighth edition appeared in igr2. The corle also appears in Medina's collection (supra, p. 48). Rives, ${ }^{3}$ an authority on the subject, has recently (1912) published what is considered the most important annotated edition of the code, including the latest related statutes and the relevant judicial decisions. The code of Cuba and Porto Rico was likewise publislied by the Revista de los tribunales." The official edition of the Philippine code ${ }^{5}$ before the American oceupation was published in $\mathrm{r} 888$.

Two excellent commentaries on the code have made their appearance. The first is the work of Nanresa, "which contains an exhaustive treatment of every section of the law. Three editions have appeared; the last, in r 9 ro, was edited by Rives who has clianged the text somewhat. The second important

1 Translation of the law of civil procedure for Cuba and Porto Rico with annotations, etc., and amendments made since the Anerican occupation. By the War Department, Division of Insular Alfairs. Waslıington, Government Printing Office, rgor. $5+4 \mathrm{p}$.

${ }^{2}$ Ley de enjuiciamiento civil de 3 de febrero de $188 x$ con las reformas . . anotada . . 8th ed. Madrid, Cóngora, rgra. 855 p.

${ }^{3}$ Rives y Martí, Francisco de P. Ley de enjuiciamiento civil de 3 de febrero de $188 \mathrm{r}$, acomodada a los últinos textos, ete. . . con notas y la jurisprudencia. Madrid, Hijos de Reus, Igr2. 2 v.

4 Ley de enjuieiamiento civil para las islas de Cuba y Puerto Rico. Por la redacción de la Revista de los tribunales. $3 \mathrm{~d}$ ed. Madrid, Góngora, r896. $73 \mathrm{r} \mathrm{p}$.

${ }^{5}$ Ley de enjuiciameinto civil para las Islas Filipinas y demás archipiélagos españoles de oceania. Ed. of Madrid, Ramón Moreno and Ricardo Rojas, r888. 556 p.

6 Manresa y Navarro, José Maria. Comentarios á la ley de enjuiciamiento civil. 3 d ed. Madrid, Hijos de Reus, Igro. $7 \mathrm{v}$. 
commentary was prepared by the Revista general de legislacion under the direction of Reus. ${ }^{3}$ Special attention is given to the citation of the relevant decisions of the Supreme Court. This work has appeared in its second edition. A useful work for the practitioner is the manual by Silvela and Barrioberro. ${ }^{2}$ It is divided into five parts. The first deals with civil procedure and contains 78 forms, including those for every possible civil action. The second covers criminal law, and suitable forms are given. The third takes up special jurisclictions, as trials in the Senate, military courts, etc. The fourth discusses ecclesiastical courts, while the fifth contains general comments by the authors.

Among the general treatises on procedure that warrant mention is the work of Lastres. ${ }^{3}$ This also includes criminal and ecclesiastical procedure. Another treatise of even more importance is that of López-Moreno, ${ }^{4}$ which includes criminal law and is annotated with the laws of all leading European 1uations. A complete treatise covering both civil and criminal procedure and notarial law is the "practical forensics" of Miguel Romero. ${ }^{5}$ Gutiérrez-Cañas's "Ensayo" is an original and fundamental discussion in four volumes of the philosophy, technique and ethics of juclicial procedure.

For procedure in bankruptcy and suspensions of payment reference inay be made to the work of Rives, ${ }^{7}$ the second edition of which appeared in 1904 .

1 Reus, Emilio. Ley de enjuiciamiento civil de 3 de febrero de $r 88 x$ concordada y anotada con gran extensión . . jurisprudencia . . por la redacción de la Revista general de legislación y jurisprudencia... 2d ed. Madrid, Hijos de Reus, 1907-1910. 1-4, 6 v.

${ }^{2}$ Silvela Loring, Jorge and Barriobe ro Armas, Juan. Manual de práctica forense. Madrid, Hijos de Reus, rgo5. $618 \mathrm{P}$.

${ }^{3}$ Lastres, Francisco. Procedimientos civiles, criminales, canónicos y contencioso-administrativos . . seguidos de t111 manual de formularios. IIth ed. Madrid, V. Suarez, I902. 2 v.

4 López-Moreno, Santiago. Principios fundamentales del procedimiento civil y criminal .. Madrid, V. Suarez, rgor. 2 V.

${ }^{5}$ Miguel y Romero, Maura. Práctica forense. $2 \mathrm{~d}$ ed. Valladolid, Fistación, Igo.4. $2 \mathrm{~V}$.

${ }^{6}$ Gutierrez-Cañas Gutierrez, Denetrio. Ensayo sobre la filosofía del procedimiento judicial, la técnica y la moral en el foro. Valladolid, Nacional y Extranjero, Inoo-05. $4 \mathrm{v}$.

7 Rives y Martí, Francisco de P. Teoría y práctica de actuaciones judiciales en materia de concurso de acreedores y quiebras. Prólogo del José María Manresa y Navarro. zd ed. Madrid, Fortanet, 1904. $2 \mathrm{v}$. 
The judiciary act, which comprises 9,32 articles, has becrl supplenented by special statutes. The most important is the recent law of unumicipal justice of Angust 5, 1907 . Others worthy of mention are the laws of April 5, and May 8, 1904, creating a speeial chamber of the High Court of Justice to take jurisdiction of contentious administrative suits, aud the law of jurisdictions of Mareh 23, 1906 . The act in annended form was extended to Cuba, Porto Rico, and the Philippines, Jannary 5,1891 .

The kingdom, including the Balearic and Canary Islands, is divided for the purpose of the administration of justice into municipal terminos, partidos and distritos. On the civil side three grades of conrts are provided for: (1) courts of the first instance (juzgado de primera instancia); (2) conrts of appeal (audicnias territoriales) for each district; and (3) the Suprene Court (Tribunal Supromo), located at Madrid. It is interesting to note that the jury is only employed in certain criminal, but not in civil, suits.

The contents of the act and an explanation of the judicial system in Spain and of the laws of procedure, especially as regards commercial matters, are discussed in pages $34^{-86}$ of the "Commercial laws of the world" (supra, p. 65). The various courts and the judicial system of the Spanish Monarchy are briefly deseribed in volume 2 ( (1914) of Case and Comment, at pages $547-550$. The judiciary act as extended to the Anerican colonies was translated in 1899 by the United States War Department." Several supplementary statutes, likewise translated, are appended. The judicial organization of the Philippines before and after the Anerican occupation, with references to the Spanish system, is discussed in the contse of an article on the administration of justice in the Philippine Istands by the Solicitor-Gencral of the Islands, George R. Harvey, in rolume nine (1914) of the Illinois Law Review, pages $73^{-97}$. Land registration, appointment of judges, admission to the bar, and other interesting topies are included.

1 Compilation of the organic provisions of the administration of justice in force in the Spanish colonial provinces and appendices relating thereto. Translated by the U. S. War Dept. Washington, Gurernment Printing Office, I899. $\quad 1 ; 0 \mathrm{p}$. 
Bravo Moltó ${ }^{1}$ in his two volume work on judicial organization includes an historical account of the courts of Spain. Sánchez de Ocaña ${ }^{2}$ also published a work on the same subject, which includes a copy of the act fully annotated. Ugarte $^{3}$ has urged some reforms in the administration of justice, which he las embodied in his work (1 9o6). The most recent statute affecting the judiciary act, the law of August 5, I907, on municipal courts, has received full treatment in the commentary of Rives ${ }^{\star}$ and in the snall but useful manual edited jointly by Rodríguez and Gutiérrez Jiménez. ${ }^{5}$ Judge Zaragoza ${ }^{6}$ of the court of first instance in Madrid edited an annotated text of the law in 1908 intended as a practical guide for the law courts.

When private rights were violated by official acts of the administration the questions of claims, or the litigation arising therefrom, were tried, from September is, isS8 to 1904, in special district courts with a separate appeal court in Madrid, the Tribunal centencioso-administrativo. The statute of September 18 , I888, was amended to a great extent by the law of June 22, 1894 , in regard to the powers and jurisdiction of this court. The law of April 5, 1904, abolished the court and created a new chamber (sala) of the Supreme Court to exercise the same powers and fulfill the same duties under the stat ute of I 894. Caballero "has published a three volume work on the subject of contencioso-administrativo, or the law governing claims against the state, but the work has not attained nuch promi-

1 Bravo Moltó, Emilio. Organización judicial vigente con una introducción 1tistórica. Madrid, Nuñez, r8go. $2 \mathrm{v}$.

2 Sánchez de Ocaña, Ramún. Organización judicial vigente. Leyes orgánicas de I5 scpticmbre I870 y de It uctubre is8z anotadas $y^{\prime}$ concordadas. Madrid, Góngora, i 804 . 800 p.

${ }^{3}$ Ugarte, Janier. Reformas en la administración de justicia. Apuntes para su estudio. Madrid, V. Suarez, 1906. 237 p.

${ }^{4}$ Rives y Martí, Francisco de P. Ley de 5 de agosto de Igo7 reorganizando la administración de justicia en los juzgados municipales, comentada y concordada . . Madrid, Hijos de Reus, rgog. 627 p.

${ }^{5}$ Rodriguez, Antonio G., and Gutiérrez Jiménez, M. Justicia municipal; manual práctico para la aplicación de la ley de 5 de agosto de I907. Madrid, J. Palacios, I008. 393 p.

' Zaragoza y Guijarro, José. Ley de justicia municipal . . annotada, ctc. . . Madrid, Gaceta de Madrid, igo8. 298 p.

“Caballero y Montes, Jusé;. I o contencioso-administrativo. Zaragoza, Escar, Igoz-1904. $3 \mathrm{v}$. 
nence. It is generally conceded by crities that the commentary of González ' is the most reliable and important on the subject. Two older treatises still retain enough authority to warrant mention-one by Alfaro, ${ }^{2}$ published in 1875 , and the other by Gallostra, ${ }^{3}$ published in 1881 . The latter ${ }^{4}$ also published a brief collcetion of the judicial decisions (jurisprudencia) in 1867 . Attention has already been called to the collections of reports of decisions and digests (supra, p. 12).

\section{NOTARIAL, LAW}

Notarial law bears a close relution to the volumtary jurisdiction of the code of civil procedure, but is governed by separate statutes. It is of far more importance than the similar institution of Anglo-American law, and the practice of the profession of notary requires long training. As public officials they are not permitted to hold other governmental positions and are governed, as the lawyers, by a College of Notaries (Colcgio de notarios). The function of a notary is to execute and certify contracts and other extrajudicial inst ruments, and to protest negotiable paper. They are required to keep the original documents and execute copies. Under Spanish law practically all deeds, contracts, and agreements of importance must be certified to by a notary, and are called thereafter instrumentos pitlicos.

The Spanish notarial law was promulgated Nay 28, 1862. This was amended by the addition of 124 articles, November 9, I 874 , and after this date numerous supplementary statutes were enacted. The law in modified form was extended to Cuba and Porto Rico on October 29, 1873. The law in force in the Philippines at the time of their acquisition by the United States was passed February 15, 1889, and the rules governing its application followed on April i , 1890.

${ }^{1}$ González, Alfonso. Ia materia contencioso-administrativa, comentario á la legislación vigente, jurisprudencia ... Madrid, I. Martínez, I903. $468 \mathrm{p}$.

${ }^{2}$ Alfaro y la Fuente, Santos. Tratado completo de lo conteneisso-alministrativo. Madrid, Nicolas González, $1875.642 \mathrm{p}$.

"Gallostra y Frau, José. Lo contencioso-arlninistrativo. Madrid, M. Tello, $188 \mathrm{r} .618 \mathrm{p}$.

${ }^{4}$ Gallostra y Frau, José. Jurisprudencia del Consejo de Estado sobre la procediencia de las demandas administrativas. Madrid, Rev. de legislación, I86\%. $88 \mathrm{p}$. 
The notarial laws as extended to Cuba and Porto Rico ${ }^{1}$ and those in force in the Philippines ${ }^{2}$ in 1899 were translated by the War Department in 1899 . There may also be mentioned the translation of the general instructions ${ }^{3}$ for drafting public documents subject to record in the Spanish colonial provinces, issued in 1893 .

A handy collection of the notarial laws of Spain was published by Medina and Marañon, , whose collections in other branches of the law have been frequently referred to. A guide to the notarial system of Spain by Escosura ${ }^{5}$ appeared in $\mathrm{I}$ S9. The well known jurist Costa ${ }^{6}$ published a work in 1892 adrocating the reorganization of the notarial system, the registry of property and the administration of justice. The work of Noroa ${ }^{7}$ on drafting of the public instruments is in fact a complete treatise of the art and science of the notary. A useful and practical work is the manual of Romero ${ }^{8}$ for the drawing up of instruments by notaries, which also includes the tariff of fees, the stamp law and the regulations governing the transfer of real and personal property. This work has been spoken of as a reritable compendium of legal information. Possibly a more extensively used nuanual for the drafting of public instruments is the work of Zarzoso, ${ }^{9}$ the sixth edition of which

'Translation of the notarial laws in force in Cuba and Porto Rico. By U.S. War Department. Washington, Govenment Printing Office, I $899.58 \mathrm{p}$.

2 The notarial laws in force in the Philippine Islands, and appendices relating thereto. Translation by U.S. Wrar Department. Washington, Government Pringing Oflice, is $99.72 \mathrm{p}$.

3 Translation of the general instructions for drafting public documents subject to record in the Spanish colonial provinces. By U. S. War Dept. Washington, Govemnent Printing Office, isog. ig p.

* Medina, Leónt and Maranón, Manuel. Leyes notariales de España conforne á los textos oficiales. Madrid, J. Rueda, 1905. $+30 \mathrm{p}$.

${ }^{5}$ Iiscostra, Gabricl de la. Guia notarial de España (públicado por r. o. de 16 de febrero de IsgS). Madrid, Piulo y Orovio, ISgS. Iv.

"Costa. Joaquín. Reorganización del notariado, del registro de la propiedad $y$ de la administración de justicia. Madrid, Rev. de legislación, I $890-1893.347$ 1).

"Novina Seoane, Ranón. Él progreso del instrumento público. ad ed. Madrid, Suc de M. Minuesa de los Rios, rgio. Soo p.

"Rom(ro y Delgado. Arturo. Nanual tcórico-práctico para la redacción de los instrumentos púlılicos. Madrid, Hijos de Rens, ryo9. 466 p.

9 Zarzoso y Tentriva, Esegual. Teoría y práctica de la redacción de instrumentos públicos. 6tlı ed. Valencia, Juan Guit, 1900. 746 p. 
appeared in 1900. 'Torre ¿ Izquicrdo" has produced two works of merit-nue, his "Examplarium," being sinnply a collection of law forms, and another work, a commentary upon the legislation governing notaries.

COSTS ANI FEES.

The law of costs is naturally associated with the law of procedure. The law on this subject is governed by the statute of December 4,1883 , which went into effect Jannary i, 188. A few clanges have been made by subsequent statutes. The official edition of the law can be obtained from the Minister of Grace and Justice. ${ }^{2}$ This statute contains a complete list of the fees for proceedings in the trial, appeal and supreme courts. Medina and Maranón (supra, p. 48 ) include it in their collection and lave annotated the different sections briefly.

Before leaving the subject of civil procedure it is well to call attention to the important convention of July i 7,1905 , between Spain, Germany, Austria-I Iungary, France, Italy, and most of the other continental conntries. The convention was ratified by the signatory powets in $1909 .^{3}$ By virtue of this agreenent, service in any of these conntries of judlicial and extra-judicial notices and process coming from any of the others is provided for. The consular officers transmit the service and notice is served by local officets. Proof of service is returned in the same way. In civil and commercial matters letters rogatory may be issued by the judicial ant hority of one count ry to that of another, requesting the performance of any judicial act or the taking of testimony. The request must be conplied with and carried out by all the usual coc cive means of compelling obedience to domestic writs. A citizen of one conntry, if sued or suing in another conntry, need not give security for costs or

I Torre é Izquicrdo, Tírso de la. Fxemplarinu. Valencia, M. Pan, $1907^{-3 .} \quad 2 \mathrm{v}$

Sane. Comentarios á la legislación notarial. Valencia, M. Pan, inot. $390 \mathrm{p}$.

2 Aranceles judiciales para los negoeios civiles, aprobados por r. d. de + de diciembre de ${ }^{8} 88_{3}$. Madrid, Ministerio de Cracia y Justicia, I $883 . \quad 1 \mathrm{v}$.

Same. In effect Feb. $\mathrm{I}, 1898$. Mialrid, Tomás Jordan, $1897.49 \mathrm{p}$.

${ }^{3}$ See 36 Clunet, r9og, pp. $853-865$ and +1 Clunet, rgit, P. 881 . 
judgment merety because he is a foreigner or doniciled in a foreign country. Other restrictions usually in force against foreign litigants are abolished.

\section{CRININAI, I,AWV.}

The ancient codes of Spain had many sections devoted to criminal law. The Sicte partidas contained the most complete and elaborate provisions, and the Nucza rccopilacion and the Norisima rcopilacion, which followed, merely repeated in detail the rules there laid down. Besides the treatment of the subject to be found in the general historical works mentioned (supra, p. 36 et seq.), one of the older legal historians Gutiérrez Fernández ${ }^{1}$ published in 8666 a useful historical account of criminal law. Dut Boys'2 French treatise, which traces the history from earliest times to the midclle of the eighteenth century, was translated into Spanish in $18_{72}$ by Vicente, who added a few new annotations and appendices. The work, from a historical standpoint, has been adversely criticized. Prof. Von Thót discussed at some length the history of the Spanish literature on criminal law in his article (pp. $35^{6}-377$ ) in the Gerichtssal, 1912.

'1he progress of eivilization and the growth of modern ideas of justice at the beginning of the nineteenth century rendered the criminal laws, because of their cruelty and harshness, out of harmony with the times. Reforms were begun as early as 1812 in the constitutional Cortes of Cadiz. The first penal code was promulgated in 1822 and a second followed in $18_{4} 8$. The constitution of 1869 contained provisions conflicting with the existing penal laws, especially those relating to personal rights, the free exercise of religious worship, punishments for various erimes committed by one person, perpetual punishments, the argolla, etc. It became necessary therefore to publish a new code.

The present code, which made but few important changes in the code of $18_{4} 8$, was anthorized by the act of $\mathrm{June} 17,18_{7} \mathrm{O}$,

${ }^{1}$ Gutiérrez Fernández, Bentio. Exámen listórieo del derecho penal. Madrid, Peñuelas, I $866.478 \mathrm{p}$

${ }^{2}$ Du Boys, Albert. Histoire du droit criminel de l'Iispagne. Paris, Durand et Pedone-Lauriel, is $870.732 \mathrm{p}$.

Version al castellano. . . con apéndiecs por José Vicente y Caravantes. Madrid, José $\mathrm{M}^{2}$ Penier, 1872. 568 p. 
and went into effect Angust 30 of the same year. Modifications of many articles were effected by the statutes of July 17 , 1876, Jamuary 1, 1900, April 9, 1900, July 21, 1904, January .3, 1907, and Jannary 3, 1908. In addition there have been enacted several more or less important laws for special erimes. The corle, considerably modified, was extended to Cuba and Porto Rico May 23, 1879 , and to the Philippines September t. 188 , although it did not go into effect there nutil December $17,1886$.

Offenses in Spain are dirided according to their nature into felonies, crimes (dclitos), and misdemeanors (fallas). The division of breaches of the law into those mala in se and mala prohibita does not exist. Following the first distinction the penal code, which consists of 626 articles, is divided into three books. Book I contains general provisions applicable to both delitos and faltas, such as the extenuation and aggravation of offenses, persons responsible, ete. Book II covers dilitos and the penalties therefor, while faltas are covered by book III.

The code of Cuba and Porto Rico was translated into English in 1898 by a comnittee ${ }^{1}$ of seven lawyers drawn from the bar of Havana. The translators state that the work was done hastily and is only substantially correct. A few brief notes are appended. A translation of this code ${ }^{2}$ as well as of the penal code of the Philippines ${ }^{3}$ was made by the War Department, in 1900. Beyond these there are no English translations of the Spanish code although the Comparative Law Bureau of the Amcrican Bar Association announces that S. P. Seott hits prepared for it a translation which is already in type (191.1). A German translation was published in 1909 by Hartwig. In a brief article in the Anunal Bulletin of the Comparative Law Bureatt (1910), pages 62--80, S. P. Scott compared Spanish criminal law with

I The penal code of the islands of Cuba and Porto Rico. Iranslated into English with explanatory notes by seven lawyers. Havana, la propagandit literaria, I 898 . $1+5 \mathrm{p}$.

a Translation of the penal code in force in Cuba and Porto Rico. By U. S. War Department, Waslington, Government Printing Oflice, I900. I75 p.

${ }^{3}$ Saine. Philippines. Washington, Government Printing Office, Inoo. I $55 \mathrm{p}$.

"Spanisches strafgesetzbuch. Translation by Alfredo Hartwig. Berlin, J. Guttentag, 1909. I2; 1). 
Anglo-Saxon law. The writer describes the contents of the penal code and compares the conduct of criminal trials with our common-law procedure. 'The theory of the Spanish penal code was compared with the French legislation in a work by Louis and Takleson Laget, ${ }^{1}$ published in $188 \mathbf{I}$.

The official edition ${ }^{2}$ of the code as promulgated in I 870 is in print, as well as the official corle ${ }^{3}$ of Cuba and Porto Rico. Bravo has published the Code as extended to the Philippines. A useful and well reconmended edition of the Spanish code is contained in the collection of the penal laws by Medina and Maranón. ${ }^{5}$ This work contains the texts of the constitution of the Spanish monarchy, the penal code, the code of criminal procedure, the jury law, the military and maritime penal codes and all the relerant statutes to 1909 . The different sections of the code as affected by the amendatory laws are printed in their latest revision, and are annotated with the important decisions of the Supreme Court. A good digest or dictionary of all the penal legislation, including procedure, has been edited by Cadalso. ${ }^{6}$ The subject matter is arranged under different topies in alphabetical order. A supplementary volume extends the work to 1908 .

Reports of judicial decisions in criminal matters have been published separately since 1874 . There is no complete digest of these although several fragmentary ones exist. Attention

${ }^{1}$ Laget, Louis, and Iaget, Valdeson. Théorie du code pénal espagnol, comparéc avee la législation française. $2 d$ ed. Paris, Marehal and Billard, I $88 \mathrm{i} .527 \mathrm{p}$.

2 Código penal reformado, mandado publicarse . . . por ley de 77 de junio de I87o. Madrid, Ministerio de Gracia y Justicia, is;o. x v.

Same. Con notas y los diseursos pronunciados en las Cortes constituyentes... ; seguido de un apendice . . leyes sobre casación criminal, reforma del proeedimiento criminal. Madrid, Rev. de legislaeión, 1870. $310 \mathrm{p}$.

${ }^{3}$ Código penal para los provincios de Cuba y Puerto Rico. Madrid, Nacional, 1879 . I79 1?.

"Bravo, Julio. Código penal vigente en las islas Filipinas ( 4 de seticmbre de is 84 ). Madrid, Nuñez, $188_{7}, 2 ; 6 \mathrm{p}$.

${ }^{5}$ Medina, Lcón, and Marañón, Manuel. Leyes penales de España conforma á los textos ofieiales. Madrid, Viuda é Hijos de Tello, Igog. 1,4801 .

${ }^{6}$ Cadalso y Manzano, Fernando. Diecionario de legislación penal, procesal $y$ de prisiones. Madrid, J. Góngora y Alvarez, $1896.3 \mathrm{v}$. with suppl. toigog. I,022 p. 
has been ealled to the crininal law reports and the digests uncler the licading of eourt reports (supra, p. 12). In this: connection, mention may be nade of the edition of the penal code by Hidalgo Garcia, ${ }^{1}$ published in 1908. All the decieions rendered up to 1908 in interpretation of the various artieles of the penal code are arranged and classified in a clear and convenient nantiner, and the work enjoys considerable reputation. A learned introduction by the distinguisluct criminologist, Bernaldo de Quirós, is also included.

There are several commentaries on the penal code. A leading work for praetical reference use is that of distinguished jurist Groizard, ${ }^{2}$ who has served as a member of the general commission of codification and is an ex-minister of state, ete. The commentary in form is somewhat tedions and prolix. The work of Viada ${ }^{3}$ of Madrid, of equal rank and anthority, is used to supplement Groizard's commentary. It is especially recommended for its examination and correlation of the relevant decisions of the Supreme Court. Supplenents earry the work to 1911. An older commentary, which was the leading anthority prior to the revision of the code in 1870 , is that by Pacheco, ${ }^{4}$ the fiscal or solieitor for the state in the Sinpreme Court. The work has been revised in two cditions subsequent to the pronulgation of the present eode, so that it still has some value.

Few general treatises of merit on the subject of criminal law exist. The leading work is Silvela's, ${ }^{5}$ of which a second edition was published by his son, in 1903 , with the necessary

${ }^{1}$ Hidalgo García, Antonio. El código penal conforme á la doctrina establecida por el tribunal supreno . . de Madrid, Rer. de legislación, 1908. $2 \mathrm{v}$.

a Grojzard y Gómez de la Serna, Alejandro. El códigro penill de is;o concordado y comentado. Salamanca, Esteban-Hermanos, 1897I $899.8 \mathrm{v}$.

3 Viada y Vilaseca, Salvador. Código penal reformado de is7o con his variaciones introducidas en el unismo, concordado y comentado . . . seguido de $u n$. . . repertorio de jurisprudencia y apendice con liss

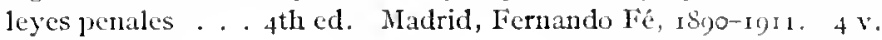
and 5 supp.

* Pacheco, Joaquin Francisco. El código penal concurdado y conentiulo. 6thed. Madrid, Mantel Tello, is8s. $3 \mathrm{r}$.

5 Silvela, Luis. İl derecho penal. Fustudiado en principios y en la legislación vigente en Iispaña. 2 d ed. Madrid, Ricardo Fè, rgoz. 2 v. 
changes required by time and references to modern theories. Prof. Dorado ${ }^{1}$ of the University of Salamanca, probably the greatest of contemporary specialists in penal law in Spain, has published a theoretical treatise covering the sources of criminal law, the interpretation of the statutes and related matters. The author originally intended this to be one volume of a larger work, but his plans did not materialize. The treatise used in the law school of the University of Madrid is that of Prof. Valdés Rubio. ${ }^{2}$ The work, although severely criticized by the profession and teachers of law, is now (1914) appearing in its fifth edition. It is principally of value for the legislation cited. The first volume of a recent (1913-14) treatise by Rovira ${ }^{3}$ has appeared, but this work has likewise been adversely criticised.

To fill the need of a good treatise on criminal law some law schools have adopted a translation of Pessina's ${ }^{4}$ well-known Italian work annotated with Spanish notes, legislation, judicial decisions, etc. The translation is likewise used by the profession in general. The latest and best edition of Pessina is that of Prof. Cuello of the University of Barcelona, issued in 1913. This is but one example of the frequent employment in Spain of foreign law books.

A unique and interesting work is the monograph of Langle Rubio ${ }^{5}$ on woman in criminal law. The crimes by and against women are discussed briefly, as well as woman's general position in criminal law; considerable space is devoted to the desertion of children which, since the Middle Ages, has been one of the crying sins of the conntry, and has multiplied the number of foundling hospitals to an incredible extent.

1 Dorado, Pedro. Problemas de dereelo penal. ad ed. Madrid, Rev. de legislación, I895. 469 p.

2 Vallés Rubio, José M. Derectio penal. 5th ed. Madrid, Asilo de Huérfanos de S. C. de Jesus, 1913. V. I ( 2 addilional vols. will appear in 1915).

${ }^{3}$ Rovira Carrero, P. I. Curso de derecho penal. Madrid, Rev. de legislación, I ${ }^{1} 3$. v. I. (Others in publication.)

- Pessina, Enrique. Elementos de derecho penal. Traducción por Eugenio Cuello. Madrid, Hijos de Reus, I9r3. 940 p.

${ }^{5}$ Langle Rubio, İmilio. La mujer en el derecho penal, Madrid, Hijos de Reus, I9II. I24 p. 
CRIMINAI, PROCEDURI:

The systen of eriminal procedure which prevailed in Spain under the ancient codes and unt il nodern times was the secret and written procodure, the lampered defense, and torture. 'This system was renounced and the aceusatory system adopted in the reforms instituted by the code (act) of ${ }_{1} \$ 82$. The present code, or act, was promulgated September I 4, i 882 , and has had comparatively few anendments. Article 954, in regard to appeal, was modified by a statute enacted August 7 , 1 S99, which expressly allowed to the heirs the civil remedies for conviction by false testimony. The code of 1582 - somewhat altered - was extended to Cuba and Porto Rico on October 19, I 888 , and becane effective Jamuary i, 1889 . This code lias been amencled in important particnlars. The extension of the code to the Philippines, in slightly modified form, occurred in $1 S 8_{4}$, but it did not go into effect there until 1888 .

There are several special statutes that bear directly upon the law of criminal procedure. The judiciary act (supra, p. 87) is naturally the most important, as the entire judicial system was organized and is governed by it. The law of April 20, 1858 , reestablishing the use of the jury in criminal trials is also inportant. This subject will be discussed more at length presently. The respective jurisdictions and powers of the administrative authorities and the judicial courts in criminal matters are defined by the royal decree of September $S$, i $88_{7}$. A special law reforming both the penal and procedural provisions contcerning smuggling and violations of the tariff law was enacted September 3, 1904. This law is rather extensive, embracing 128 articles.

The law of crininal procedure now in force contains 998 articles and a final provision, classified under seven divisions or books. Book one deals with general provisions, jurisdiction of courts geographically and by degree of crimes, rights of challenge, prosecution and defense, procedure, exceptions, decisions as to matters of form, jurisdiction, sentences, sun1mons, comnunications between conrts, appeals and costs. Book two considers the sumario, or prelininary investigation, corresponding to that of a grand jury. Book three takes up public and oral trials. Special proceedings and extradition, 
appeals and reviews, prosecution of faltas, or nisdemeanors, and the execution of sentences are treated of sticcessively in books four, five, six and seven.

A complete analysis of the code of criminal procedure was made soon after its promulgation by a French lawyer, Thenrault, in the twelf th volime of Annuaire le législation etrangère (1882), pages 693-720. He discusses each section and summarizes its contents. Verdier and Depieges ${ }^{1}$ made a translation of the code in 1898 under the authority of the French government, which has caused many of the important foreign codes to be translated for the benefit of its own lawmakers. The code as in force in Cuba and Porto Rico is included in the translations made by the War Department (supra, p. 48), and was also published ${ }^{2}$ separately with the text in Spanish added.

'The text of the code of criminal procedure is of ten included in the same volume with the penal code, and sometimes with the code of civil procedure under the head of procedural laws. The Revista de legislacion ${ }^{3}$ published an annotated edition of the code of criminal procedure, soon after its promulgation, in two volumes. The required forms for pleading are given. A recent edition of the code is printed in the collection of criminal laws by Medina and Maranón (supra, p. 94). Amat ${ }^{4}$ in 1903 published a small annotated edition of the code. The Revista de los tribunales issues newly annotated editions from tine to time.

The court decisions on criminal procedure, from the promulgation of the present code until 1893 , have been collected and digested in the form of a mantual or handbook by a law writer who signs his name R. D. V. ${ }^{5}$ Attention may also

${ }^{1}$ Code de procedure eriminelle espagnol (14 septembre 1882). Traduit et annoté par Gabriel Verdier and Joseph Depieges. Paris, Impr. nationale, 1898 . $404 \mathrm{p}$.

2 Translation of the law of criminal procedure for Cuba and Porto Rico (with Spanislı text) with annotations ... By U. S. War Department, Washington, Government Printing Office, 1901. 393 p.

${ }^{3}$ Ley de enjuiciamiento criminal de 14 de septiembre de 1882 , concorda y anotada.. por la redacción de la Revista general de legislación y jurisprudencia ... Madrid, Hijos de Reus, 18831884. $2 \mathrm{~V}$.

- Anat, Vicente. Ley de enjuiciamiento eriminal comentada y anotada ... Barcelona, Sopena, r903. 395 p.

${ }^{5}$ R. D. V. Manual de jurisprudencia procesal en materia crinninal (18821893). Madrial, Góngora, 1894. I v. 
be called to the work of Herrero Martinez on crininal procedure in all Spanish courts from the lowest municipal court to the Suprene Court at Madrid. It is practically an exlaanstive digest of decisions of the court of last resorts on the niost important points of criminal law. Appended to nearly cvery article is a series of questions which are answered by eitations of, or references to, fecisions on the matters in question. 'The work contains no forms.

A valuable contribution to the literature of crininal procedure is the commentary recently conmenced, but only partially completer, by Agnilera de Paz." "The commentator is a judge of one of the appeal courts and an anthor of several inportant legal works. The commentary is to encompass five volnmes when completed, but at present (1914) only three have appeared.

In the recent English translation of Eismein's ${ }^{3}$ history of continental criminal procedure, published as one of the Continental legal history series, a few pages $\left(295^{-301}, 5^{8}+-585\right)$ are devoted to Spain.

Treatises on eriminal procedure lave been of ten conbined with treatises on civil procednre, notably in the works of Lastres (supra, p. 86) and López-Moreno (supra, p. 86). The conplete and useful mannal of Silvela and Barrioberro (supra, p. 86) also includes crininal law. Soon after the promulgation of the code of criminal procedure, in 1882 , several treatises were published explanatory of the new law. Among those that warrant mention are the works of Marfa, ${ }^{4}$ and of Armas 5 in collaboration with Dominguez-Alfonso. A brief work on

${ }^{1}$ Herrero Martínez, Mariano. Ley de enjuicianicnto eriminal reformada. Valladolid, Castellana, 1900. 846 p.

2 Aguilera de Paz, Enrique. Comentarios a la ley de enjuiciamiento criminal. Madrid, Hijos de Reus, 1913. $3 \mathrm{v}$. and cont.

3 The Continental legal history series. A history of continental crininal procedure with special reference to France. By A. Esmein. Translated by John Simpson. Boston, Little, Brown and Co., 1913. $640 \mathrm{p}$.

4 Marfá, Juan. Simplificación de la nueva ley vigente de cujuiciamiento criminal (de it de septiembre de 1882). Barcelona, Peninsular, $188_{3}$. $1060 \mathrm{p}$.

${ }^{5}$ Armas y Saenz, Ranón and Domínguez-Alfonso, Antonio. Práctica del nuevo enjuiciamiento criminal de if de septienbre de isS2. Madrid, Fortanet, I $883.6391 \%$ 
the admission of evidence in criminal cases was published in I 9 Io by López Infantes. ${ }^{1}$

The question as to how far expert testimony can be profitably received on an issue of criminal law and under what necessary safeguards has been admirably discussed by Dorado, ${ }^{2}$ professor of criminal law in the University of Salamanca. Such important questions as the weight to be given expert evidence of physicians, the right of a lawyer to press the defense of emotional insanity, etc, are critically discussed. The author advocates the education of criminal judges in medical jurisprudence in order to confine the influence of the experts within proper limits.

Several matters of eriminal procedure are of especial interest for investigators of Spanish law. Among these may be mentioned the fact that the courts occupy a micldle ground between the rule of presumption of innocence and that of presumption of guilt. This position is often said to be less conducive to miscarriages of justice than either of the two extremes. A statute of limitations, relating both to delitos and faltas, is provided for under the eriminal code (sections 132-135). Crimes involving capital punishment or life imprisonment can not be prosecuted after a lapse of 20 years; and lesser offenses, after periods varying from two months to fifteen years.

JURY LAW. - The jury was employed in Spain as early as 1820 in trials of offenses committed by the press. A somewhat broader scope was later given the system, but in .1875 the entire institution was suppressed. The act of April 20, 1888 , reestablished a modified form of the jury system and gave it jurisdiction to sit in cases of felonies and some misdemeanors. The jury was never extended to Cuba, Porto Rico, or the Philippines by the Spanish government, and does not now exist in many of the Mexican states and the other SpanishAnerican countries. An exposition and diseussion of the text of the Spanish law was published by Bravo Moltó, ${ }^{3}$ president of the Criminal Chamber of the Supreme Court, immediately upon its appearance.

${ }^{1}$ López Infantes, Lcopoldo. Apreciación de la prueba en nuateria criminal. 2 d ed. Madrid, Hijos de Rues, 1910. $152 \mathrm{p}$.

${ }^{2}$ Dorado Montero, Pedro. Las peritos medicios $y$ la justicia criminal. Madrid, Hijos de Reus, 1906. 291 p.

${ }^{3}$ Bravo Moltó, Fímilio. Ia lcy del jurado. Madrid, Nuñez, I888. $270 \mathrm{p}$. 
The text of the law has been translated into French in an appendix to the translation of the law of criminal procedure, by Verdier and Depieges (supra p. 98). A good edition of the text of the jury law, annotated and supplied with relevant rules for the adnission of evidence and various forms required, was prepared by Sínchez de Ocaña ${ }^{1}$ immediately after its promulgation. The nost useful work for judges and lawyers, however, is the treatise of Garcia, ${ }^{2}$ in two volunes, witl a supplement.

Another practical, but less extensive, guide to the jury law by Judge Vipegon ${ }^{3}$ appeared in 1901 , in which the leading foreign codes are compared with the Spanislı law. This and García's work are in current use. A well recommended commentary on the jury law is the work of the jurist Pacheco; ${ }^{*}$ it appeared in 1888 following the enactment of the jury law. No recent commentary has been published.

The work of Rodríguez Pinilla ${ }^{5}$ ( 1873 ), though now old, is yet of pernanent value in the history of law. He traces the origin of the jury and discusses its advantages in the first half of his work. The second half he devotes to comparing the jury aystems of France, Ingland, and Portugal. At that tinie, the reorganization of the jury was a question of much importance in Spain.

Tile Sumario.-Every criminal trial in the more serious offenses is divided into two stages. The first stage is the sumario, which has no exact equivalent in our procedure. In effect, it is similar to the secret investigation of a grand jury. After the crime has been committed and the criminal apprehended, he is kept in solitary confinement while the state, througl a judge of the first instance and its attorney ( $f$ iscal), conducts a thorough ex parte investigation. The Spanish Constitution (arts. 4-5) prohibits the detention of accused persons except

${ }^{1}$ Sáncliez de Ocaña, Ramón. Código manual del jurado. Madrid, Rev. de legislacion, ISSS. I60 p.

"García y Ronnero de Tcjada, José. Iil libro del jurado. Jerez, "Iil guadalete," I $894-1897.2$ v. and supp.

${ }^{3}$ Vipegon. Guía de los jurados. Madrid, Ricardo Fé, 19or. 28 I p.

4 I'acheco, Irancisco de. La ley del jurado conentada por . . . con un prólogo del Manuel Alonso Martíncz. Madrid, Rev. de legrislación, 1888. 9+1 p.

${ }^{5}$ Rodriguez Pinilla, lomás. Eil jurado y su estableciniento en Españi. Madrid, I a constitución, 187 . 196 P. 
for just causes. The proceedings based on this constitutional provision are the nearest approach in Spanish law to our habeas corpus. The sumario has been treated of in a monograph by Saiz y Gómez.' 'To this work there is appended a description and comments on the organization of the criminal conrts.

Conditional or Suspended Sentence.-The law of March 17, 1908, authorizing the employment of the conditional sentence (condena condicional) requires special mention. It is an important step in the reform of Spanish law. The law provides for the suspension of sentences under certain circumstances. Bernaldo de Quirós (infra, p. I06) has compared the system with our American system of probation, except that in the latter no sentence is pronounced in the first instance. This innovation in criminal procedure is still the object of lively discussion in Europe and theorists are divided on the question of its advisability.

The Revista de los tribunales 2 has published the above statute with an historical and explanatory discussion of its 11se, together with the proyectos and discussions produced prior to its enactment, with some relevant foreign legislation. The law for delinquent minors is also appended. González del Alba, ${ }^{3}$ president of the appeal court of Madrid, has published an annotated edition of the statute. Every section is supplied with copious comments by the annotator and relevant supplementary laws. The introduction to this work came from the pen of the criminologist Bernaldo de Quiros.

Capital PUnismient.-Capital punishment still exists in Spain althongh there has been in the past a great agitation for its abolition. The jurist Torres Campos" has championed the canse of the opposition and his memoir published in pamphlet form, is possibly the best known work on the subject. This article is summarized and reviewed in rolume

1 Saíz y Gómez, Miguel. Jîl sumario y el juez de instrucción. Con un apéndice que contiene . . ideas sobre organización de los tribu. nales, ete. Madrid, Góngora, I 890 . I V.

${ }^{2}$ I ey de 1 j de marzo de igo 8 sobre condena condicional . . . por la redaeción de la Revista de los tribunales. Madrid, Góngora, rgos. I 70 p.

${ }^{3}$ González del Alba, Primitivo. La condena condicional. Madrid, Hijos de Reus, rgos. I20 p.

4Torres Campos, Manuel. La pena de muerte, y su applieación en España. Madrid, Góngora, 1879. Pamphlet. 
25 of the Jonrnal of jurisprudence (1881), pages 35-38. A work relating to the "death penalty," which warrants nention because of its nerit and interesting contents, is the "studies" of González Naudin. ${ }^{1}$ This work gives a complete history of this form of punishment, especially as to the tortures inflicted in the eighteenth and nineteenth centuries. The Spanish penal laws abound in excessive and cruel punishments, some of which are reflected in the codes of the Philippines, Cuba and Porto Rico. Under the American administration of these territories the eighth amendment of the Constitution of the United States is sometimes invoked. Prof. Schofield has published an interesting article in the fifth Illinois Law Review (1911), pages 32r-335, discussing the question.

INDEMNITY FOR ERROR OF JUSTICE.-Infringements by wrongful convictions of the legal rights of defendants, under certain circumstances, are repaired by civil liability of the judges and punished by heavy fines and imprisonment. The law of August 7,1899 , provides that when the judge is insolvent the state itself will indemnify the unfortunate victim to the extent of his injuries. A comparative study of the various European systems of state indemnity for errors of criminal justice was recently published by Dr. Edwin M. Borchard in the Journal of criminal law and criminology, volume 3 (1913), pages $68 \mathcal{f}^{-71} 8$, and reprinted as United States Senate Document 974, sixtysecond Congress, third session.

\section{MILI'TARY CRIMINAL LAW}

Military and naval courts in Spain have a much broader jurisdiction than similar courts in the United States. In addition to jurisdiction over persons in the service they can try civilians in certain cases, as, for example, in cases of minor crimes involving property belonging to either branch of the service. The nilitary law of Spain is governed by the code of military justice, codigo de justicia militar, promulgated September 27,1890 . This code is, in fact, a compilation of three earlier statutes with some minor adjustments. These three are the organic law of March 10, 1884, organizing the courts of war (Tribunales de guerra), the military penal code of December $17,188_{4}$, and the law of military procedure (ley de enjuiciamiento militar) of November 29, 1886 . The code of

${ }^{1}$ Conzález Naudin, Sebastian. Estudios sobre la pena de muerte. Madrid, Rev. de legislación, 1872. Io4 p. 
1890 lias been modified by a few later statutes, especially those of August 7, 1899, January 1, 1900, and August 25, 1904. The Supreme Couneil of the Army and Navy (Consejo supremo de guerra y marima) was organized under the law of December I 7, 1890 . This law contitins over two hundred articles defining the powers and duties of the officials and the manner of procedure and records.

The code of military justice is composed of seven luundred and fifty articles arranged in three books. Book one treats of the organization and powers of military courts, their eivil and military jurisdiction. Books two and three take up the military erimes and procedure.

The military and naval laws are included in the collection of penal laws by Medina and Maranon (supra, p. 94). The annotated edition of the code of military justice by Nido ${ }^{1}$ is practically a commentary and is perhaps the most usef ul work on the subject. Soon after the promtngation of the code Sánchez de Ocaña ${ }^{2}$ published an annotated edition.

The legislation governing the army is published officially by the Minister of War. ${ }^{3}$ A dictionary or encyclopaedia of legislation on military matters was published by Rodriguez Jinénez ${ }^{*}$ in 1903 .

Several treatises dealing with the subjeet of military courts liave appeared. Assistant Solieitor Piquer ${ }^{5}$ of the Supreme Couneil published in 1906 a work deseribing the organization, powers and the procedure of military courts. A practical pocket guide for the administration of military justice was issued in 1910 by Trapaga and Blanco de la Viña. ${ }^{6}$ Procedure

1 Nido y Torres, Manuel del. Código de justicia militar, comentado $y^{t}$ concordado. Madrid, La Correspondencia militar, 1911. 10641).

2 Sánchez de Ocaña, Ranón. Código de justicia militar de 27 de septiembre de 1890 anotado y concordado. Madrid, Góngora, I 890. $591 \mathrm{P}$.

${ }^{3}$ Leyes constitutivas del ejército y organicas del estado mayor general . . hasta el fin de diciembre 1896 . Madrid, Depósito de la guerra, 1896. 214 p. with supplement.

" Rodríguez Jiménez, Eusebio. Diccionario de legislación militar, ó consultor del dereclıo administrativo militar, compendio general ... Madrid, Depósito de la guerra, Inoz. $2 \mathrm{v}$.

${ }^{5}$ Piquer y Martin Cortes, Rafael de. Los tribunales de guerra . . Madrid, López y del Horno, 19o6. $3^{\$ 2} \mathrm{P}$.

Trapaga y Aguado, Adolfo and Blanco de la Viña, Crerrado. Cartera de bolsillo para la administración de justicia militar en el ejército. Madrid, Patronato de huérfanos de admr. nilitar, rgro. $85 \mathrm{I} \mathrm{p.}$ 
before the courts, both of the war and navy, is disenssed in a treatise by Cabrerizo. ${ }^{3}$

Naval jurisdiction is considered as a part of the military establishnent, but is governed by some special laws. The penal code of admiralty of August 24,1888 , governs this jurisdiction, together with the law of maritine courts of justice and naval procedure of November 10, 1 S94, as amended by the act of Jantuary I, 1900 . Soon after the promulgation of the eode of 1888 , Romero ${ }^{2}$ published an edition with bricf comments and some annotations. An official edition of the code appeared in 1894 , published by the Department of the Navy. A good commentary containing all the laws governing the naval jurisdiction and all the statutes of necessary application in this field appeared in 1895 , from the pen of Moreno. ${ }^{3}$ The Department of the Navy ${ }^{1}$ from time to time publishes the legislation concerning that department.

In Spain, as in other continental countries, military service is obligatory. In 1912 Trapaga ${ }^{5}$ published a practical guide to the application of the act or law governing this service. A manual dealing with the pensions of widows and orphans of soldiers was published in rgro by Saball, ${ }^{6}$ a writer of authority.

The Supreme Council of the War and Nayy issues officially a monthly bulletin which contains among other items of interest the decisions of the military courts.

${ }^{1}$ Cabrerizo, F. Fil defensor ante los tribunales de guerra y marina. Madrid, Ministerio de marina, 1905. 282 p.

${ }^{2}$ Romero y Villanueva, José $\mathrm{M}$. Código penal de la marina de gucra, de 24 de agosto de i888. Con connentarios y un prólogo de ... Madrid, Núñez, Isss. $272 \mathrm{p}$.

${ }^{3}$ Moreno y Lorenzo, Joaquin. La jurisdicción de marina. Tratado de todas las leyes y disposiones de, ete. . . Madrid, Hijos de J. A. García, 1895 . I016 p.

${ }^{4}$ Coleceión legislativa de la armada. Madrid, del Ministerio de Marina. 1906. I $v$, with suppl.

strapaga y Aguaclo, Adolfo. Guia práctica para aplicir la ley del servicio militar obligatorio. Madrid, Cuerpo intendeneia militar, 1912. $480 \mathrm{p}$.

- Saball, Fernando. Manual de las pensiones de vińdad y orfandad que corresponden a las familias de generales, jefes y oficiales del ejército. Madrid, López del Horno, ıэг. 39 I p. 


\section{CRIMINOLOGY AND REFORM OF CRIMINAL LAW}

Modern ideas of criminology and reforms in criminal law did not reach Spain as early as they did the other countries of Europe, due perhaps to its western loeation and scientific seclusion. Although Spain was one of the first countries to take a census of its criminality ( 729 ) and the practice of compiling annual statisties began early in the nineteenth century, these had bureaucratic rather than scientific aims. Recently, however, rapid strides have been made in the actual application of scientific reforms as well as in the advancement of the science itself.

The naines of Bernaldo de Quirós and Dorado Montero stand pre-eminent in the list of Spanish writers on criminology. Bernaldo de Quirós's work on "Modern theories of criminalit $y^{\prime}$ " is the leading general treatment of the subject in Spain and has won recognition as an authoritative work in the world's literature of criminal science. The scond edition, especially revised, was translated under the auspices of the American Institute of Criminal Law and Criminology ${ }^{1}$ as the first volume published in its modern criminal science series. The distinguished author is engaged in research work for the Instituto de Reformas Sociales (infra, p. 1 20) and has produced numerous interesting and usef ul monograplss on various topies in the field of criminology.

'The first treatise or expository presentation of merit of the science of criminology by a Spanish author was published by Dorado. ${ }^{2}$ It is interesting to note that this work dealt with criminal anthropology in Italy. Dorado's leading work and probably one of the greatest of Spanish works on criminal law is his "Problems of criminal law" (supra, p. 96). The same author has since published several modern books on various subjects in the field of the law. His "Bases for a new penal law" 3 and "New penal methods" "attracted much favor-

1 Bernaldo de Quirós, Constancio. Modern theories of eriminality. Translated by Alfonso de Salvio. Boston, Little, Brown and Co., I9I. 249 ].

¿ Dorado Nontero, Pedro. La antrojología criminal en Italia. Madrid, Rev. de legislación, I889. I v.

"Dorado Montero, Pedro. Bases jara un nuevo derecho penal. Barce. lona, M. Soler, igoz. zoI 13.

${ }^{4}$ Uorado Montero, Pedro. Nuevos derroteros penales. Barcelona, M. Soler, Ig05. I V. 
able conment. Mention should likewise be made of his "Criminology and penology"1 (1906) in which is inserted an earlier study on criminality in Spain during the period of the regency (1885-1902). An original and interesting work is his criminal psychology in the Spanisl legislation ${ }^{2}$ which gives a broad, learned and philosophical vicw of crininal psychology in its relation to statutory cnactments. This was originally intended only to apply to the penal code but the autlor was led by his investigations to include all the criminal legislation.

Among other general treatises on the subject of criminal anthropology is the carly work of Martinez Ruiz. ${ }^{3}$ The first part of the treatise is devoted to a description of the growth and sources of the new science. A nore recent work by Carpena ${ }^{4}$ on this subject is attracting attention anong jurists and students of the science for its elucidation of the cause of crine and its prevention. The "forermners of criminal science in Spain" by MLntes " is a study" of the delinquent and of the causes of crime and their remedies. A treatise by Aramburu ${ }^{6}$ on the new criminal science offers interesting reading. Lombroso, the late eminent Italian criminologist, published an interesting and suggestive article, in 1910 , in volume 31 of the Italian criminological review, Archizio di antropologia criminal, pages $54^{6-551}$, on the cause of Spanish criminality. He describes Spain as a "classic" land for the study of criminality.

Attention should he called to the works of two other foreigners who have made valuable contributions to the study of criminality in Spain. Agusto Bosco, ${ }^{7}$ in his "Crinninality in various comntries of Europe," devotes an entire chapter to

1 Dorado Montero, Pedro. De eriminologia y penalogia. Madrid, Rodriguez Serra, 1906. $224 \mathrm{p}$.

2 Dorado y Montero, Pedro. La psicología criminal en nuestro dereeho legislado ... ad ed. Madrid, Hijos de Reus, s911. $35^{8} \mathrm{p}$.

${ }^{3}$ Martinez Ruiz, José. La sociologia criminal. Madrid, Ricardo lé, 1889. 2 Iо $\mathrm{p}$.

4 Campena, Fructioso. Antropologia criminal. Madrid, Fernando lié, 1909. 522 1.

s Montes, J. Gerónimo. Preeursores de la ciencia penal en İspañil. Madrid, V. Suarez, I9I r. 7.5 p.

* Aramburu y Zuloaga, Feliz de. La mueva ciencia penal. Madrid, Fé, $1887.377 \mathrm{p}$.

7 Bosco, Augusto. La delinquenza in vari stati di Europa. Rone, R. Aceademia dei Lincei, 1903. $282 \mathrm{p}$. 
Spain. Ferri ${ }^{1}$ in his works on criminology also discusses briefly the conditions in Spain.

Numerous useful discussions of specific aspects and studies of criminality have been made by Bernaldo de Quirós, Llanas Aguilaniedo, Ruiz (Max Bembo), José Varón y Caballero, Gil Maestre, and the well known Rafael Salillas. These monographs, while of considerable interest and value, are believed to be beyond the scope of the present guide.

Reforms in the penitentiary system and the prison laws of Spain have been treated of by several writers. Cadalso ${ }^{2}$ in 1893 puljlished a work on prisons. Lastres' ${ }^{3}$ work on the same subject is several years older. In 1901 Albó ${ }^{4}$ prepared in pamplilet form a sketch for the reformation of the existing penitentiary law. Concepción Arenal (supra, p. 26), one of the few women jurists who have won an international reputation, has been most active in reforms of criminal law and penology. In r gor she published a four-volume collection of discussions, etc., on public charities and prisons. ${ }^{5}$

A magazine (Revista penitenciaria) devoted to criminal reforms was edited from 1904 until 1909 in Madrid by Salillas. Within its files may be found numerous valuable contributions to the literature of the reform movement in criminal law.

The distinguished legal historian and philosopher, Hinojosa," has enriched the literature of this field by his work on "the

1 Ferri, Finr. Sociologia criminale. $4^{\text {th }}$ ed. Torino, fratelli Bocca, I000. 900 1).

Same. L'omicidio nell' antropologia criminale. Torino, Bocca, I $895-2 \mathrm{r}$.

${ }^{2}$ Cadalso y Manzano, lernando. Estudios panitenciarios. Presidios españoles. Fiscuclas clásica y positiva y colonias penales. Madrid, Góngora, ISo3. 2 v.

[Second rol. entitled " Principios de colonización y colonias penales.']

${ }^{3}$ Lastres, Francisco. Estudios penitenciarios. Madrid, Nuñez, I\$87. $236 \mathrm{p}$.

"Albó y Mlarti. Ramón. Apuntes para un projecto de reforma penitenciaria. Barcelona, Miguel Borrus, rgor. Pamplilet.

s Arenal, Concepeion. Obras sobre beneficiencia y prisiones. Madrid, V. Suśrez, igoi. \& v.

${ }^{6}$ Hinojosa, liduardo. Influencia que tuvieron en el derecho público de su patria y particularmente en el derecho penal, los filosóficos y teólogos españoles anteriores a nuestro siglo. Madrid, Huérfanos, ISgo. I9g p. 
influences which the Spanish philosophies and theologists anterior to our century have had on public law of the country and partienlarly on eriminal law."

\section{CONSITUTIONAI, IAIV}

Derecho politico as employed in Spain has two significalions,-a broad meaning equivalent to political science in general, and a restricted or narrow one of constitutional law. Under the title of political law, anthors frequently diseuss merely constitutional law, with oceasional digressions into political science.

The first constitution of Spain, exeepting the lirench Constitution du Bayonc in 1808 , was franced during the enforced absenee of Ferdinand VII, in is 80 , and promulgated in 1812. Since 1 S 2 not less than six distinet constitutions have been adopted in the Peninsula in addition to various renewals, amendments and abrogations. The present constitution was adopted in 1876 , but has been amended through the efforts of the I,iberal party since 1881 by the addition of provisions for minersal sufirage for men, trial by iury, liberty of the press, ete. There are several linglish translations of this doenment. Walton ineludes it in his "Civil law in Spain (supra, p. 36)." Professor Dodd ${ }^{2}$ in his collection of the fundancntal laws of the most important comntries of the world presents a translation with historieal and bibliographic notes (volume II, pp.

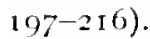

A recent $(1913)$ edition of the constitution, copionsly annotated by González, 2 is well recommended. Prof. Dodd used as the hasis of his translation the current edition of Góngora which also ineludes supplementary laws. The last edition ${ }^{3}$ appeared in 1910. The texts of all the Spanish constintions may be found in a two volume collection of constiLutions edited, in t $8 S 6$, by a group of lawyers ${ }^{4}$ in Madrid.

${ }^{1}$ Dodd, Walter Fairleigh. Modern constitutions. Chicago. Eniv. of Chicago Press, I gog. $2 \mathrm{~V}$.

2González, Adolfo. Constitución de la monarquía española. Madrid, V. Suarez, IgI3. Izo p.

3Constitución politica de la monaryuía espñola y leyes complementarios por la redacción de Revista de los tribunates. 7thed. Madrid, Góngora, 1910. $22+\mathrm{p}$.

${ }^{4}$ Constituciones de Españi y de las demás naciones de Furopa . . por una sociedad de jurisconsultos. Mádrid, Liscribano y Echevarría, 1886. 2 v. 
The government publishes officially from time to time collections of political documents including all the constitutions, various amendments and other papers, for the practical use of the Spanish parliament.

General treatises on derecho politico, as has been observed, sometimes extend beyond the field of constitutional law. Among such works, attention may be called to those of Colmeiro, ${ }^{1}$ the more recent treatise of Gil Robles ${ }^{2}$ and Prof. Santamaría de Paredes' ${ }^{3}$ Curso de derecho politico. The last work (8th ed., I 909), while general in scope, is more especially useful for its sketch of Spanish constitutional history.

The leading and most anthoritative contemporary writer in the field of derecho politico is Prof. Posada, of the University of Madrid. He has made contributions to practically every branch of the subject. In 1884 he published a treatise on the principles of public law ${ }^{4}$ which was intended to serve as an introduction or outline of a greater undertaking. In pursuance of his plan there lave appeared a two-volume treatise on the fundamental (politico), or constitutional, law ${ }^{5}$ (revised 1914); a two-rolume treatise on administrative law (infra, p. 112 ), published in 1894 ; a brief guide ${ }^{6}$ for the study of constitutional law, containing the principal constit utional documents of the world (1894); and finally, in 1908, a short treatise $^{7}$ comparing the different methods of teaching political science, recent changes in the law and various methods of

1 Colmeiro, Manuel. Elementos del derecho politico $y$ administrativo de España. 7th ed. Madrid, Viuda ह́ hija de Fuentenebro, is87. $312 \mathrm{p}$.

Same. Curso de derecho político según la historia de León y Castilla. Madrid, F. Martínez García, 1873. 6 is p.

2 Gil Robles, Enrique. Tratado de derecho político según los principios de la filosofia y el derecho cristianos. Salamanca, Torre, 18991002. $2 \mathrm{v}$.

${ }^{3}$ Santamaría de Paredes, Vicente. Curso de derecho-politico . . . con un prólogo de Eduardo Pérez Pujol. Sth ed. Madrid, Ricardo Fé, I $909.8_{32} \mathrm{p}$.

* Posada, Adolfo. Principios de derecho político: introducción. Madrid, Murillo, 1884. $350 \mathrm{p}$.

${ }^{5}$ posada, Adolfo. Tratado de derecho político. 2 d ed. Madrid, V. Suarez, IgIt. $2 \mathrm{~V}$

- Posada, Adolfo. Guía para el estudio y aplicación del derecho constiucional de furopa y Anérica. Madrid, V. Suarez, I894. 280 p.

7 Posida, Adolfo. Derecho político comparado. Madrid, V. Suarez, 1906. 25 I P. 
comparing the law as employed by noted scicutists. It may be added that in 1914 Prof. Posada ${ }^{1}$ prepared a work on Spanish public law for the series Das offintliche liecht der Gryenzart.

J. I. M. Curry, ${ }^{2}$ late Minister of the United States to Spain, prepared in 1889 an interesting discussion or shetch of the development and history of constitutional government in Spain.

Prof. 'Torres Campos ${ }^{3}$ the same year published in German a brief memoir on the public and constitutional law of Spain which also appears in the fourth volume (ist hall, sth part) of the Handbuch des offentlichen Rechts. 'The Crerman (imelin," in r 1905 , made a study of the constitutional developucut of Spain. Professor Giner de los Rios in his Estudios (supra, p. 23) offers a few interesting monographs covering topics in the field of dercho politico. An important work on self-government and the doctrinarian monarchy, by Azcárate, ${ }^{5}$ published in 1877 , may atso be noted.

An interesting treatise by Pons ${ }^{6}$ presents an extended discussion of the organization and powers of the national congress, or parliament (Cortes), according to the different Spanish constitutions.

\section{ADMINISTRATIVE LAW}

The texts of all the administrative laws of Spain, annotated briefly with decisions of the suprene court, have been conpiled in one handy volume by Medina and Maranón. ${ }^{7}$ Among

' Posada, Adolfo. Spanisches staatsrecht. 'Tubingen, Siebeek, 1914. $2+6 \mathrm{p}$.

2 Curry, J. L. M. Constitutional government in Spain. New Jork, Harper and Bros., 1889.222 1.

3 Torres Campos, Manuel. Das staatsrecht des kònigreichs Spanien. I'reiburg, J. C. B. Mohr, 1889. $125 \mathrm{p}$.

- Gmelin, H. Studien zur spanischen verfassungsgeschichle des neunzelinten jahrliunderts. Stuttgart, F. Finlic, 1yo5. $207 \mathrm{p}$.

${ }^{5}$ Azcárate, Gumersindo de. Eil self-gozemment y lit monarquía doctrinaria. Madrid, Peña, 1877. 299 p.

${ }^{6}$ Pons y Umbert, Adolfo. Organización y funcionamiento de las cortes según las constituciones españolas y reglanentición de diclu cuerpo colcgislador. Madrid, Hijos de Hernández, 1906. 7331 .

'Medina, León and Maranón, Manuel. Leyes administrativis de Isspaña. Malriel, Viuda é Hijos de Tello, 1907. 1,400 p. 
the laws included are those in regard to industrial and intellectual property, waters, ports, mines, railroads, eminent domain, upkeep of public property, public charities, public works, contentious-administrative courts, ete. This work, like the other collections of the same compilers, is currently used. The publishing loutse of Gongora in Madrid edits the administrative laws in convenient volumes, keeping them up to date. The most valuable collection of laws relating to Spanish public administration is the diccionario of Martinez Aleubilla (supra, p. I6). It is indeed a legal encyclopedia, and covers practically every branch of Spanish law. Other useful encyclopedias including all administrative laws are cited under "General works" (supra, p. I5).

Reports of court decisions on administrative questions are published separately. Reference has been made to these under "Court reports" (supra, p. 12). Since the abolition of the special contentious-administrative court these decisions are handed down by a special chamber (sala de lo contenciosoalministrativo) of the Supreme Court at Madrid. The special jurisdiction contencioso-administrativo and its literature have been referred to under "Civil procedure" (supra, p. 88).

The best brief treatise on Spanish adninistrative law is the work of Santamaría de Paredes ${ }^{1}$ which has recently appeared in a seventh edition (19II). The author is a distinguished member of the faculty of law of the University of Madrid. The introduction to the work was written by the jurist Pérez Pujol. A lengthier but older treatise was published by Abella ${ }^{2}$ in 1888 . Royo Villanova ${ }^{3}$ is the author of another useful work on this subject. A brief treatise appeared in 1907 from the pen of Prof. Gascón ${ }^{4}$ of the University of Seville. A work of some merit was produced in I 898 by the wellknown publicist, Adolfo Posada. ${ }^{5}$ Jurisdietional conflicts be-

'Santamaría de Paredes, Vicente. Curso de derecho administrativo.

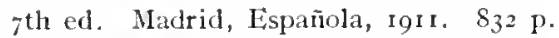

${ }^{2}$ Abella y Blave, Fermin. Tratado de derecho administrativo español. Madrid, Administración, 1886-r\$88. $3 \mathrm{v}$.

${ }^{3}$ Royo Villanova, Antonio. Elementos de derecho administrativo. Valladolid, Castellana, 1909. $2 \mathrm{~V}$, in $\mathrm{I}$.

${ }^{4}$ Gascón y Marín, José. Nociones de derecho administrativo y legislación provincial y municipal. Madrid, Hijos de Reus, r90\%. 292 p.

${ }^{5}$ Posada, Adolfo. Tratado de derecho administrativo segín Ias teorías filosófica y legislación positiva. Madrid, V. Suarez, 1897-8. 2 v. 
tween the exccutive and judicial powers have been treated in at recent work of Ubierna.' A recent (1917) work worthy of note is the collection of studies by Villar," a lawyer of Madrid. Four separate topies in administ rative law are discussed.

'Translations of various administrative laws in force in the islands of Cuba, Porto Rico, and the Plilippines at the time of the Spanish-American War have been made by the Division of custonis and insular affairs of the War Department. In many instances the provisions are identical with the laws of Spain. A compilation of laws and decrees dating from September 12, is70, to December 31, 1896, relating to the civil administration and government of Porto Rico ${ }^{3}$ was translated in I 899 . There has also been translated the general law of public works of Cuba," regulations for its execution and a collection of laws referring to public works in Porto Rico. ${ }^{5}$

\section{MUNICIPAL AND PROVINCIAL ADMINISTRATION}

Municipal customs have played an important rôle in the development of continental legal history. The customary municipal law of Spain las been discussed in a brief work by Costa ${ }^{6}$ in collaboration with two other jurists. Abella, ${ }^{7}$ in 1877 , and Blas, ${ }^{8}$ in 1882 , published works on provincial and

${ }^{1}$ Ubierna y Eusa, José Antonio. Conflictos jurisdiccionales entre los poderes ejecutivo y judicial. Madrid, R. Velasco, IgII. 3i p p.

2 Villar Grangel, Domingo. Estudios de dereelıo administrativo. Madrid, Hijos de Reus, 1914. 294 p.

${ }^{3}$ Laws relating to the civil administration and government of the island of Porto Rico. Translated by War Department. Washington, Government Printing Office, ISgg. $53 \mathrm{p}$.

4 Translation of the general law of public works of the island of $\mathrm{Cuba}$ and regulations for its execution . . Washington, Government Printing Oflice, I 899 . $101 \mathrm{p}$.

5 Translation of collection of laws referring to public works in Puerto Rico (1896). By U. S. War Department. Washington, Government Printing Office, I 899 . I I 2 p.

'Costa, Joaquin; Pedregal, Manucl and Linares, Gervasio de. Derecho municipal consuetudinario de Fispaña. Madrid, Rcv. de legislación, 1885 . $128 \mathrm{p}$.

7 Abella y Blave, Fermín. Derccho administrativo provincial y municipal. Madrid, la Riva, $1877.6 \mathrm{v}$.

s Blas y Melendo, Andrés. Derccho municipal y provincial. Madrid, Jezcano y Comp., r882. 354 p.

$77231^{\circ}-15--8$ 
municipal administrative law, the former in six volumes. The law of mnnicipal justice of 1907 has already been discussed (supra, p. 87). Abella ${ }^{1}$ has prepared a mannal for municipal officials, which is in fact a practical treatise on municipal administration. It has gone through six editions. An interesting discussion of the legislative evolution of loeal government in Spain from 1812 to 1909 was published by Posada ${ }^{2}$ in 1910.

Prof. Gascón y Marín ${ }^{3}$ prepared an elementary work on administrative law, with speeial reference to provinces and municipalties. He followed the outline or plan used in the examination of applicants for secretaryships in the municipal govermments. The modern municipality, its powers and duties, is the subject of an interesting work by Rodriguez Ilartin, ${ }^{4}$ a judge of a court of first instance. Administrative questions, such as public order, hygiene, taxes, vagrancy, etc., are discussed. The munieipalization of public utilities has been discussed by Craseón y Marin. ${ }^{5}$

Speeial attention may be directed to the encyclopedia or dictionary, compiled by Aleu (supra, p. 16), of all technical terms employed in the administration of municipalities. The work really is an encyclopedia of Spanish law but is designed especially for mumicipal administrative and judicial officers. The second edition, in eight volumes, was completed in 1911.

The munieipal and provineial laws in force in Cuba and in Porto Rico are closely related to the Spanish laws. Translations of both were nuade in 1899 by the United States War Department. ${ }^{6}$

${ }^{1}$ Abella y Blave, Fermin. Manual del secretario de ayuntamientos ó tratado teórico-práctico de administración municipal. Madrid, Viuda é hijos de la Riva, I892. oth ed. $866 \mathrm{p}$.

${ }^{2}$ Posada, Adolfo. Evolución legislativa del régimen local en España. is12 a igog. Madrid, V. Suarez, rgio. $5^{13} \mathrm{p}$.

${ }^{3}$ Gascón y Marin, José. Nociones de dcrecho administrativo y legislación provincial y municipal. Madrid, Hijos de Reus, 1907. 292 p.

- Rodriguez Martín, Antonio. El municipio moderno. Madrid, Hijos de Reus, I907. 294 p.

${ }^{5}$ Gascón y Marín, José. Municipalización de servicios públicos. Madrid, V. Suarcz, I904. $289 \mathrm{p}$.

- Translation of the municipal and provincial laws in foree in the island of Cuba. By U.S. War Department, Division of customs and insular affairs. Washington, Government Printing Office, 1899 . 7x p.

Translation of the provincial and munieipal laws of Puerto Rico. Washington, Govcrnment Printing Office, 1899. $5^{8} \mathrm{p}$. 


\section{THLCTIONS}

A good book on clectoral procedure in Spain was published in 1897 by Anclret. ${ }^{1}$ Giralt ${ }^{2}$ in 1901 prepared a manual of the electoral legislation. Sanz ${ }^{3}$ has publisher a practical guide and explanation of the application of the act of 1907 , which changed the form of electing represcntatives (diputados) to the Cortes. The electoral law of 1800 was extended in anended form to the islands of Cuba and Porto Rico. A translation was made of the law, and atso of the special law for the election of councilors and deputies in Porto Rico, ${ }^{5}$ by the War Department of the United States.

\section{WATLRS}

The civil code defines the ownership of waters under the heading "Special kinds of property," but the specific laws governing water rights, irrigation and related matters is cmbodied in a special enactment call the Ley de aguas (law of waters). It was first cnacted in is 866 and was extended to the Philippines in 1871 . In 1879 a new and elaborate law was enacted in the Peninsula, conststing of 15 chipters and some general provisions. This was extenderl to Porto Rico in I 886, but was never extended to the Philippines. The law for Cuba, ${ }^{\circ}$ extended to Cuba by special decree of Jan. 9, I891, was translated by the United States War Department in 1900. Franquet, ${ }^{7}$ in 1864 , published a work on the origin and history of

t Andren y Serra, R. Procedimiento electoral in lispaña. Bareelona, Henricli y Comp., r897. I v.

${ }^{2}$ Giralt y Verdaguer, Joaquin. Manual de la legislación electoral. Bazeclona, López, rgor. I v.

${ }^{3}$ Sanz y Caminalo, Joaquin. Ley electoral para diputados á cortes y concejales. Madrid, Hijos de Reus, rgos. I $2+\mathrm{P}$.

4 Adaptation of the electoral law of June 26,1890 to the islands of Cuba and Porto Rico. Translated by War Department, Division of Customs and Insular Affairs. Waslington, Government Printing Office, I $899.23 \mathrm{p}$.

- Electoral law for the election of couneilors and provincial deputies in Porto Rico. Translated by War Department, Division of Customs and Insular Affairs. Washington, Government Printing Office, I S99. $92 \mathrm{p}$.

6 The law of waters in foree in the island of Cuba. Translated by llar Department, Division of Customs and Insular Affairs. Washington, Government Printing Office, I900. 53 p.

' Francuet y Bertan, Cirilo. Ensayo sobre cl origen, espíriti y progresos de la legislación de las aguas. Madrid, Ducozcal, is64. 2 v. 
the legislation enneerning waters. The author presents the laws governing waters as contained in the ancient codes and in modern legislation. The legislation of present importanee conmenees with the Ley de aguas of June 13 , IS79. A convenient compilation of this and sueeeding laws governing all inland waters, ports, canals, ete. was published by Aleu ${ }^{1}$ in 1912. The Revista de los tribunales ${ }^{2}$ also issues annotated compilations eovering the same subjects.

HUNTING AND FISHING IAWS

Spain's bird law was first enaeted September 19, I 896. The government moreover beeame a party, in 1905 , to the international agreement for protecting birds useful to agriculture. After the passage of the amending statutes of May, I 902 , and $\mathrm{Ju} 1 \mathrm{y}, \mathrm{I} 903$, Abella ${ }^{3}$ issued a new edition of his earlier manual of the hunting laws. The Revista de los tribunales ${ }^{4}$ recently (1912) published a work on the laws governing hunting and fishing, annotated with the decisions of the courts. Two other useful works may also here be mentioned. The first is a manual of the legislation governing sea fishing by González and Sánchez, ${ }^{5}$ and the other a eollection of international treaties and agreements concerning fishing and fishing rights compiled by López. ${ }^{5}$ The usefulness of the latter work is increased by annual appendices eontaining the latest agreements.

\section{MINES}

Mining law is governed by a special act which has been frequently amended. The first Ley de minas (mining law) was

' Aleu Cerrera, Manuel. Legislación de aguas, puertos, canales y pantanos. Madrid, Biblioteca "J11sticia," I912. $653 \mathrm{p}$.

${ }^{2}$ Redacción de la revista de los tribunales. Compilación de la legislación de agnas, canales de riego, ctc. $3 \mathrm{~d}$ ed. Madrid, Góngora, 1902. $5^{12} \mathrm{p}$.

Abella y Blave, Formín. Mannal de derecho de caza y uso de armas. 3d ed. Madrid, Administración, 1903. 324 p.

${ }^{4}$ Legislación de caza, uso de armas y pesca. Por la Redaccion de la Revista de los tribunales. Marlricl, Góngora, 1912. I27 p.

5González y Maroto, F., and Sáncliez y Jiménez, M. Manual de legislación sobre pesca marítima. Madrid, Asilo de Huérfanos del S. C. de Jesús, 1906. $687 \mathrm{p}$.

${ }^{-}$Ioppez y Medina, F. Colccción de tratados internacionales, ordenanzas y reglamentos de pesca. Madrid, B. Cerrada, I9o6. 192 p. 7 app. 101914. 
enacted in 1859 and revised in 186.3 . During the last half of the nineteenth century a great incruase in the industry denanded many reforms. An article deseriptive of the mining laws of Spanish conntries by one of the present day jurists, Cabello, was read at the meeting of the International Law Association, held in Madrid, October, 1913, and was printed in its reports with an Inglish sumnury. This interesting article was reviewed and summarized in volnme 39 (1913) of the Law magazine and review, pages $83-96$. The Spanish mining laws were translated into French by Stevenson ${ }^{2}$ in $591 \mathrm{I}$. The law as extended to Cubis ${ }^{3}$ by royal decrees of Oetober 10, 1883, and June 27, 1884, was translated by the War Department, with an appendix containing all the decrees issued to r goo. The law in force in the Philippines thas also been translated.

Two good compilations of the mining legislation of Spain were made in 1912 by Carrerra ${ }^{5}$ and Abella ${ }^{6}$ respectively. An extensive work on mining law was publislued in 1890 by R. and M. Sánchez de Ocaña. It gives the history of the legislation and a collection of the texts of the varions laws as well as judicial decisions. The work is well annotated and its appendices extend to 1898 . The volume of $\mathrm{M}$. Sánchez de Ocaña ${ }^{8}$ appearing in 1905 supplenents the preceding compilation. A treatise of some importance was published by Car-

' Cabetlo y Guillén de Toledo, Alfonso. Leyes de minas en las países españoles. With English summary. London, R. Flint, $1913.38 \mathrm{p}$.

2 Stevenson, A. Codes miniers ... Fispagne. Paris, Dunod and Pinat, IgII. I+I P.

${ }^{3}$ Translation of the mining law applied to Cuba by royal decrees of ... with appendix contaning all provisions issued to date. By Waar Iepartment, Division of eustoms and insular affairs. Washington, Gurernment Printing Office, igoo. 95 p.

4 Translation of the mining law and regulations in force in the Philippines. By War Department, Division of custons and insular affairs. Wishington, Government Printing Office, rooo. $7^{\text {S p p. }}$

"Carrera, Manuel Aleu. Legislación de minas. Madrid, "Justicia," I912. $6+6$ p.

-Abella y Blave, Fermin. Manual de legislación de minis. oth ed. Madrid, Administración, 101 $1.765 \mathrm{P}$.

- Sáncluez de Ocaña, Ramin ancl Sanchez de Ocaña, Maxino. Legislación minera. Madrid, Enrique Marotos y hermane, $1890.702 p$. 2 app.

"Sánchez de Ocaña, Maximo. Nueva legislacinn minera. Maltrid, llijus de Reus, 1005. $220 \mathrm{p}$. 
bonell ${ }^{1}$ in 1906; it contains an account of the legislation from 1868 on, and inuch practical information. Since 1906 one important statute has been enacted, the act of 1908 establishing a mining council. An encyclopedia of mining law in one volume was published in 1906 by Prats and Hernández Pinteño. ${ }^{2}$

\section{PUBLIC FINANCE}

Medina and Marañon ${ }^{3}$ have prepared an annotated collection of all the statutes and laws relating to the Hacirnda priblica, or the public treasury, finances, public property, tariffs, taxes, etc., but the usefulness of the collection is impaired by a lack of revision since i 894. A collection of the important statutes relating to the public finances has recently (1913) been published by Vila Serra. ${ }^{*}$ A treatise on the public treasury and finances by Villa ${ }^{5}$ appeared in 1907. An older treatise (5th ed., 1900) of Piernas ${ }^{6}$ enjoyed considerable authority but the second volnme is at present out of print. Three well known legal writers ${ }^{7}$ published in 1900 a treatise on the accounting system of the Spanish govermment. The budget, its liquidation, the systems of the national and provincial treasuries, collection of taxes, etc., are some of the topies discussed. The work is especially designed for the information of governmental officials. The experiments of the Spanish government in coinage have been discussed by Henry Charles Lea in an article which appeared in volume 51 (1S97) of the Popular science monthly, pages 577-593.

A manual of the tax laws governing the alienation and transnission of property according to the law of 1900 , was prepared

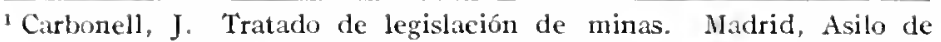
Huérfanos del Sogrado Corazón de Jesús, 19o6. $56+$ p.

${ }^{2}$ Prats y García-Clalla, José and Hernández Pinteño, José. Finciclopedia jurídica minera. Madrid, Rev. de legislación. 1095 p. 1906.

${ }^{3}$ Medina, León and Marañón, Manuel. Leyes de hacienda de Fspaña. Madrid, Manuel Tello, $1894.2 \mathrm{v}$.

${ }^{4}$ Vila Serra, José. Legislación de lraeienda pública. Valencia, Impr. del autor, 1913. 71 +1 ).

${ }^{5}$ Villa y Lindemán, Diego. Hacienda pública. Madrid, Hijos de Reus, 1907. $212 \mathrm{p}$.

${ }^{6}$ Piernas Hurtado, J. Tratado de liacienda pública. 5th ed. Madrid, V. Suarez, 1900. $2 \mathrm{v}$.

"González Cedrón, Antonio; Méndez de Vigo, Leonció and Peral, Florentino Iimilio. Nociones generales de contabilidad públiea. Madrid, Hijos de Reus, rgoo. 915 p. 
by Abella, ${ }^{1}$ a prolific writer in the field of alninistrative law. A manual ${ }^{2}$ of territorial tax laws has cone from the pen of the same editor.

The recent (1913) collection of tariff legislation, with tables for importation and exportation duties, was prepared hy the editorial louse of Cóngora. ${ }^{3}$ A translation 'into linglish of the customs tariff in force in 1912 is obtainalie.

The civil code, in book II and part of book III, contains complete provisions covering real property. In articles 605608 , generil rules for the registration of property are found, but the nortgage law (supra, p. 6o), with its supplementary acts, and the notarial laws (supra, p. 89) provide specific requirements for registration of real estate. All the laws, orders and decrees governing the registration of real property in both Spain and the colonies, enacted from January $1,197+$ to Deccmber 31 , iS82, were published officially in two volmmes by the General Director of Registration. ${ }^{5}$

A collection of the laws, ordinances and regulations, adopted by the government of Spain, relating to the disposition of public lands in her colonies was compiled in 1828 by Joseph II. White (infra, p. 139). The public land laws in the Philippine Islands, witl an historical account up to 1899 , were collected by the IForestry Bureau in 1901 (infra, 1) 1.39).

POOR LAWS

Spain is a country in which much poverty prevails and the government has had to maintain many public charitable organizations. The editorial house of Góngora issues from time

${ }^{1}$ Abella y Blave, Fermin. Manuel del impuesto de derechos reales y transmision de bienes. $7^{\text {th }}$ ed. Madrid, Administración, igm. $27 \mathrm{I}$.

2 Abella y Blave, Fermín. Manual de la contribnción territorial. Ftl ed. Madrid, Administración, 1910. $767 \mathrm{p}$.

${ }^{3}$ Legislación de aduanas; aranceles de importación y exportación para la Peninsula é islas Barleares. Madrid, Góngora, Ig I3. 300 [?.

4 Translation of the new customs tarifi of Spain with comparison of duties leviable prior thereto. Iondon, H. M. Stat. Darling, 1912. 37 p.

${ }^{5}$ Colección oficial de leyes, reales decretos . . que se han dictado referentes al registro de la propiedad inmueble $y$ de los demás derechos reales desde el $\mathrm{r}^{\circ}$ de enero de $187+$ hasta el $3 \mathrm{r}$ de dieiembre 1882. . Por la direceión general de los registros civil de la propiedad... Madrid, Ministerio de Gracia y Justicia, 1882-1884. $2 \mathrm{v}$. 
to time useful collections of the legislation in this field. A complete manual including all the laws, ordinances and regulations of bencficencia (poor laws) was published in 1912 by Abella. ${ }^{1}$

\section{I,ABOR LEGISI,ATION}

Spain, finally awakened to the need of modern labor legislation by numerous strikes and a general unrest of the working classes during the last years of the nineteenth century, is now in the midst of a rapid and wonderful development in the field of social legislation. The inactivity of the country in industrial pursuits and the fact that a large proportion of its population is engaged in agriculture have rendered the enactment of laws perhaps less imperative than has been the case in other countries of western Europe. Yet, since 1899 , the practical beginning of the progressive legislation in Spain, a considerable advance has been nuade.

Through the initiative of Noret, the Minister of the Interior, who recognized the inadequacy of the provisions of the civil code, the Comision de reformas sociales was, in $188_{3}$, established by the government to investigate labor conditions in Spain. One of the most important questions considered by the commission was that of coinpensation for industrial accidents. They produced a progran of legislation, June 7,1887 , but it was thirteen years before a statute based upon it was enacted. The commission was succeded by the present Institute of Social Reforms (Instituto de reformas sociales), established by royal decree of April 23, I 903. The purpose of the Institute is to study the labor problem in Spain and elsewhere, compile statistics, inspect the condition of workers, and make recommendations for new legislation. It is composed of thirty active nembers, eighteen chosen by the government, and twelve elected, six by the employers and six by the laborers. In addition, there are four ex officio members. Leading sociologists and representatives of all creeds and political parties are included in the commission. The excellent service rendered and the legislation seeured-of vital inportance for the protection of the laborer-reflect much credit upon the Institute. In 1912 it published a con-

\footnotetext{
'Abella y Blave, Fermín. Manual de beneficiencia. Madrid, Admin. istración, 1912. 5 II P.
} 
densed report, ${ }^{1}$ diseussing its organization and operations, as one of its bulletins, which in general comprise the best literature on labor legislation in Spain.

Labor eonditions in Spain and the legrislation up to 19 in are diseussed in the valuable lirench work of Marvaud ${ }^{2}$ on the social question in Spain. A short account of Spanislı labor legislation since 1899 was published in volume 5 of the American political seience review (1911), jages 249-2.5.3, by Clarence Perkins, and an article on the labor laws then in force by Dr. Simancas, of Madrid, appeared two vears previously in the journal of the Belgian Institute of Comparative Law (vol. 2, Revuc di l'lustitut de droit compare (1909), 86-95). References to foreigin legislation are frequently made by way of comparison. Probably the best general description and condensation of the social labor legislation is the section by l'osarla in the work Dovecho usual (supra, p. 18).

There are several collections of the texts of the labor laws conveniently annotated. The latest $(1914)$ was compiled by Medina Fernández, ${ }^{3}$ the prosecuting or State's attorney in the Audencia of Valladolicl. The work include's all the legislation, as well as forms for labor contracts and an explanatory introduction. The Rezista de los tribunales ${ }^{4}$ publishes complete and useful collections of the labor laws, annotated with decisions of the Suprene Court and sonte forcign conts. The work was considerably enlarged in the 1913 edition. The collection published by the lnstitute of Social Reforms, in 1905 , is kept up to date by speeial anmual appendices. The Institute also publishes projeets of proposed laws as, for instance, in 19 I a draft law governing the labor contract,"

1 Memoria referente a la organizacion y funcionamiento del instituto de reformas sociales. Madrid, Sne. de M. Minuesal de los Rios, ror 2. $103 \mathrm{p}$.

${ }^{2}$ Marvaud, Angel. I a question suciale cn lispagne. Paris, IF. Alcan, 1910. 4751 ).

${ }^{3}$ Medina fiernández, Marino. Compilación cudifieada de lat legislación obrera en España. Valladolis, Cuesta, igit. 4is p.

- Revista de los tribunales. 1xegislación obrera . . concordada y anu. tada con Ja jurisprudencia españula y extranjera. 3 rd ed. Madrid, Góngora, r9i3. $680 \mathrm{p}$.

"Instituto de reformas sociales. Legislación del trabajo. Madrid, Sise. de M. Minuesa de los Rios, $1905.35 \mathrm{p}$.

"Instituto de reformas sociales. Projectu de lay solore el contratis de trabajo. Madrid, Minnesa de los Rios, rgne. 528 p. 
and in 1913 the draft of a law governing the hours of labor of elerks in mercantile establishments. ${ }^{1}$ The manual of Vila Serra ${ }^{2}$ is currently used.

The recent (1914) treatise of Prof. Gutierrez-Gamero ${ }^{3}$ of the Industrial School of Madrid, although brief, discusses in a clear namer the social movement in Spain, current legislation, organizations of labor and capital, strikes and finally labor contracts. Two monographs of Buylla," "the workman and his laws" and "the protection of the workman," should not be omitted. The international development of labor legislation has been discussed by a lawyer, Sangro, ${ }^{5}$ who is also associate editor of the Spanish edition of the publications of the international association for the legal protection of laborers. Sangro's ${ }^{6}$ lectures on the intervention of the state and the munieipality in labor questions, delivered before a religious convention in Barcelona in I912, have attracted much attention. He treats the subject rather theoretically, citing, however, extracts of existing laws.

The Spanish edition of the publication of the International Association for the legal protection of laborers was inaugurated in 1907 under the editorship of Dato, Buylla, Sangro, Oyuelos, and others. It issues are irregular, thirty-three numbers having appeared up to June, 19I4. These contain numerous articles of referential value. In regard to protective laws for mine laborers, the Institute of Social Reforms ${ }^{7}$ published

IInstituto de reformas sociales. Preparación de un projecto de ley regulando la jornada de trabajo de las personas empleadas en los establecimientos mercantiles. Madrid, Minuesa de los Ríos, I9I3. $19^{2} \mathrm{p}$. Contains foreign legislation and bibliography.

2 Vila Serra, José. Manual de la legislación del trabajo. Valencia, Inipr. del autor, rgro. $638 \mathrm{p}$.

${ }^{3}$ Guticrez-Gamero, Francisco. Legislación industrial. Asociaciones, lutelgas, contrato de trabajo. Madrid, 1*. Moliner, 1914. $286 \mathrm{p}$.

"Buylla y Alegre, Adolfo. El obrero y las leyes. Madria, Rev. de Iegislación, 1905. $373 \mathrm{p}$.

Puylla y Algre, Adolfo. La protección del obrero. Madrid, V. Suarez, 1910. $25^{8} \mathrm{p}$.

s Sangro y Ros de Olano, Pedro .. I a evolución internacional del derecho obrero. Madrid, V. Snarez, I9ı2. $396 \mathrm{p}$.

"Saugro y Ros de Olano, Pedro. I a intervención del estado y del municipio en enestiones obreras . . Barcclona, P. Ortega, igri. i52 p.

i Instituto de Reformas Sociales. Información sobre el trabajo en los minos. Madrid, Minuesa de los Ríos, r910. I03 p. 
some statistical information in 1910 , and Sanz, Sallilas, and l'uyol, a committce appointed by the Institute, made a thorough and complete report of the nines in Vizeaya in 190.4 .

WORKMEN'S INSURANCE AND FMIPIOYTRS' WMBILTY

Only the first steps lave as yet been made by Spain in the field of social insurance. Two inportant measures have been passed-the compensation act of Jannary 30,1 , yo, and the act of February 27, 1908, establishing a nat ional institute for oll-age pensions.

The law of January 30, 1900 ("law in recard to industrial accidents') is the workmen's conpensation act of Spain. Before its passage the compensation of workmen for industrial accidents was based npon the criminal and civil lability provisions of the civil code, articles I 902-1910, which provisions were derived from the Roman legal ideas of responsibility for the consequences of one's own acts or for the acts of one's agent. Its legislative history dates from the draft project formulated by the Connussion of Social Reforms, June 7, isS7. This plan was referred to a committee of the Senate which returned it to the Commission with instructions for further claboration. On May 2, 1891 , a revised draft was presented, but it was not until June 5,1894 , that there was introduced into the Cortes a bill in accordance with the conmission's recommendations. 'The bill net with strong opposition and failed to becone law. Finally on December 2, 1899 , the bill for the present act was int roduced and becane law on Jannary 30, 1900 . This aet establishes the main principles but hardly enters into details of procedure and adninistration. The Government was directed to publish all necessiry regulations within six months. The legislation now in force in addition to the law of Jannary 30,1900 , includes the decree of July 28 , 1900 , forming a complete set of regulations; the decree of August 27,1900 , in regard to accident insurance companies; and the decrees of March 26 , and July 2, 1902, extending the application of the law to the War and Navy departments, respectively. In addition, a number of less important royal orders (ordenes reales) interpreting certain articles of the law

'Sanz y Iscartin, Finardo; Sallillas, Rafacl and Puyol y Alonso, Julio. Minas de Vizcaya. Madrid, Minuesa de los Ríos, 1004. 331 p. 
or modifying preceding decrees have been promulgated from tine to time.

A complete analysis of the law of 1900 and of all decrees and orders up to the elose of 1910 appeared in the twentyfourth annual report of the United States Commissioner of Lahor, vol. II, pages $2321-2376$. The entire question of workmen's insurance in Spain is discussed, and a translation of the act of 1900 is ineluded at pages $2705-2707$ of the same volume. This law is also described in detail by L. Léger in the Annales des scicnces politiques, volume 2 I (1906), pages 494-5 I5, and by Delearde in the fifteenth volume of the Bullctin du Congres international des accidents du trazail (1904), pages 56-94.

The law provides rates of compensation in detail for all degrees of injuries to employees arising out of or in the course of employment, unless eaused by zis major and forces extraneous to the employment in which the injury occurs. There are also qualifications relating to fraud, imprudence or negligence of the workman. It is applicable to cmployees in government works, such as arsenals, ammunition works, etc., and the govermment, including state, provincial and communal adminis tration, is treated like a private employer for the purposes of the law.

It is interesting to note that the compensation act of 1900 contains no special provisions for agricultural laborers and is not applicable to them except where machinery propelled by stcam, etc., is employed, despite the fact that Spain is mainly an agricultural country. The Instituto de Reformas Sociales las published a proposed project of a special compensation act for this class of workmen. It is probable that in the future the new legislation will follow this line of division.

Employers are not compelled to insure against accidents to their employees, nor is there required a guaranty fund from which payment can be made to the injured parties under the compensation act. Hence, in case the employer becomes insolvent the law can have little effect. The Government, however, endeavors to stimulate voluntary insurance on the part of employers by offering them an opportunity of relieving themselves of liability by insuring in certain casualty companies. The employer must bear the expense of the insurance and the amounts paid to the injured employees are carefully olserved to see that they are not less than those allowed by 
law. Such casualty companies are under the striet superrision of the covernment. They are regulated by the roval decree of August 27, 1900, antl orders of October 16, and November 10, 1900. The decree of Augnst 27, 1900, is translated in the "Commercial Laws of the World" series (supra, p. 65), volume XXXI1, pages 279-281.

The compensation of workmen for industrial accidents has been discussed by numerous law writers. The statute is so rcent and changes are being made so often that the latest work is the most useful. An annotated text of the workmin's compensation act, with all amendments, is included in the greneral collection of labor laws (supra, p. 121). A good mannal of the act with its supplementary laws appeared in 1911.' This contains also the Sunday rest law (Descanow dominical, infra, p. 129) of $190+$ with its amendments. The annotated collections of Catalá, ${ }^{2}$ containing the compensation act, the laws for insurance against accidents, wages, industrial courts and regulations for mine labor, may be recommended. The decisions on the workmen's compensation act were pulylished in 1906 by the Institute of Social Reforms. ${ }^{3}$ Two appendices carry the work to date $(1914)$.

Directly following the promulgation of the compensation act sereral tratises appcared. Among these may be mentioned the works of listasén,' Anmatell 'lusquets, ${ }^{5}$ and González Rebollar, ${ }^{6}$ all of practically equal merit. Each contains

'Manual de accidentes del trabajo, proteción á la infancia y descanso dominical .. p por Justia. Madrid, Bibliolcca "Justicia”, Igr I. $429 \mathrm{p}$.

${ }^{2}$ Catalá y Gavilá, Juan Båutista. Iegislación obrera . . . con todas las cisposiciones legales... jurisprudencial, ete. Madrid, Adninistración, I01 I. $3^{82} \mathrm{p}$.

3 Instituto do reformas sociales. Jurisprudencia de los tribumales en materia de accidentes del trabajo. Madrid, Minnesa de los Ríos. 1906. $21 ; 1$, 2 app.

${ }^{4}$ Isstasén, Pedro. Ios aceidentes del trabajo y el seguro de accirlentes. Marlrid, Hijos de Rcus, 1903. $638 \mathrm{p}$.

5 Aumatell Tuscuets, Francisco. Isos accidentes del tribajo. Fisturlio de la ley de zo de enero, 1900 y . . complementarias . . seguido de un sucinto examen comparativo de lis legislación extranjera. Barcelona, Penella y Bosch, 1003. $29 S_{1}$ ?.

"González Rebollar, Hipólito. Tey de accidentes del trallajo. lisudidios crítico de la ley española de zo de enero de inoo. . . comparades con las principales legislaciones extranjeros . . Silananca, Cilón, á cargo de $\mathrm{A}$. Iglesias, $1903.506 \mathrm{p}$. 
the Spanish legislation up to 1903 and practically covers the same ground. A more recent work is the short commentary of Nido, ${ }^{1}$ annotated with the decisions of the Supreme Court. The practical use of the work is enhanced by full and complete forms for the drawing up of necessary legal papers. l'robably the most useful and important treatise on the subject is that published by Ricardo Oytuelos, ${ }^{2}$ a recognized atthority. This contains, in addition to the doctrinal statenlents, the texts of the legislation, judicial decisions, at well as foreign legislation for comparative purposes. The publication of his supplementary work, "Code of social reforms," 3 extends the legislation to $19^{13}$. The latter is merely a collection of the statutes and decisions in force in 1912.

The compensation act has not proven entirely satisfactory. The novement for revision began in 1904 on the initiative of the labor delegates to the Institute of Social Reforms. On June 28 , 1907, the Institute completed a draft of a proposed new bill and this bill was int roduced in the Cortes, practically withont change, by the Minister of the Interior July I6, 1910. It failed to become a law.

The subject of social insurance lias been covered in brief fornu in a recent (1913) treatise of López Nuñez." It has received high commendation. Insurance for labor accidents and old age, as well as savings' banks, fraternal organizations, personal risks, etc., are some of the matters discussed. The Instituto Nacional de Prevision and the laws governing it are explained.

Sickness insurance of workmen is comparatively new in Spain. The progress made so far is due to private or cooperative efforts, withont any interference, assistance, or regulation by the government. The existing institutions for medical or financial assistance during illness, which are organized n11ore or less upon an insurance basis, may be classified in

${ }^{1}$ Nido y Torres, Manuel del. Ley de accidentes del trabajo. Comentada.. Sevilla, Escuelas profesionales de artes y ofícios, r9ı. $265 \mathrm{P}$.

2 Oynclos, Ricardo. Tratado de legislación y jurisprudencia de accidentes del trabajo. 2 d ed. Madrid, R. Rojas, igo6. 6.42 p.

${ }^{3}$ Oyuelos, Ricardo. Código de reformas sociales. Colección de las leyes $y$ de la jurisprudencia vigentes. Madrid, Scaevola, 19.3. 26 I p.

'López Nuñez, Alvaro. Lecciones elementales de previsión. Madrid, Suc. de Minuesa de los Rios, 19I3. 245 p. 
INDUSTRIAL AND ARIBTRATION COMMISSIONS. 127

three groups: (1) The commercial sickness insurance companies; (2) the mutual sick benefit socielies; and (3) the special funds of charitable organizations.

The system of governmental pensions to military and civil employees is highly developed in Spain. Nevertheless, little had been done in the field of old-age and permanent injury insurance for wotkmen until the National Institute for OldAre Insurance was established by the law of Fichruary $2 S$, igos, although there had been great need for governmental assistance for some time. The lnstitute is endowed loy the goverument and its purpose is to stimulate the popular interest in savings, in insurance and especially in old-age insurance as well as to encourage other local institutions of the same type. Practically, the operations consist in selling old-age pensions or deferred annuities to individuals of the working classes. The voluntary character of the insurance is the essential feature of the system, and the employers are not recpuired to make any contributions to the fund. The law of February 27, r9o8 and succeding laws for the guidance of the Institute are included in the collection of mutual and oldage insurance laws published recently by the Revista de los tribunales.

INDUSTREAL, CURTS ANI ARBITRATIN COMMISSIONS

Industrial conts were established by the law of May i 9 , 1908 and the locations of the individual courts were fixed by the law of October 20, 1908 . Some changes were made by the law of July 22, 19r2. These court s are composed of a presiding judge, three jurors and an alternate ehosen by the interested workmen from a list presented by the employers, and the same number chosen by the employers from a list presented by the workmen. The court thus constituted has jurisdiction over differences between employers and employed in matters concerning the nonfulfilment or annulment of contracts to provide workmen, contracts to work, apprenticeship agreements, and over differences regarding the application of the workmen's compensation act. Appeal from the decision of this court lies to a second court composed of a presiding

${ }^{1}$ I.egislación de seguros, mutualidad y previsión con tablas, modelos . . . por la redacción de la Revista de los tribunales. Madrid, Góngora, 1912. $720 \mathrm{p}$. 
judge, seven jurors and two alternates chosen from the enployers, and the same number chosen from the employees. The complete text of the law of May 19, 1908 was published in volume 4 (1908) of the Bolctin of the Institute of Social Reforms, pages 1278-1287. A brief commentary of the law was published by López ${ }^{1}$ in 1909 . A discussion of industrial courts by Puig Martínez and Mascare $11^{2}$ was published in 1909. Labor accidents are also included in the work.

On the same date a law was passed establishing councils of conciliation and industrial arbitration. A labor dispute must be presented to the local council or junta a certain length of time before a strike is called, and an attempt is made to settle the trouble by arloit ration. Compulsory arbitration, however, is not yet provided for and the juntus are not required to eome to a final settlement. A law dealing with strikes and unions and recognizing the right of employers to organize and enployed to organize and strike was passed, January 27, 1909, through the efforts of Prime Minister Maura. 'This law makes all strike leaders (considering as such all officers in unions as well as those who actually arouse the workmen by writings or speeches) responsible for illegal acts of the strikers. The inciters of an illegal act receive the maximum penalties, while only the minimum is imposed on those actually committing the act. Strict rules for adrance not ices of impending st rikes, etc., are included. 'This law has been severely criticized by many of the republicans and socialists on the ground that it tends to make a successful strike extremely difficult.

1.ABOR ORGANIZATIONS

A history of the development of labor organizations in Spain since the twelfth century was prepared by Una ${ }^{3}$ in 1899. The Ateneo of Madrid rewarded the anthor with a nnonetary prize. The German writer, Kulemann, ${ }^{4}$ in his recent (1913)

${ }^{1}$ Jópez, Francisco R. Ley de tribunales industriales de 19 de mayo de Igo\$ y la legislación del trabajo. Almeria, El Triunfo, rgog. $454 \mathrm{p}$.

2 Puig Martinez, César and Mascarell Llacer, Larazo. Tribunales industriales. Accidentes del trabajo. Valencia, F. Sempere y Comp., 1900. $294 \mathrm{P}$.

"Uña y Sarthon, Juan. Las asociaciones obreras en España. Madrid, C. Juste, $1000.374 \mathrm{P}$.

"Kulemann, W. Die Rerufsvereine. Vol. 5. Jierlin, Berlag von L. Simion 1913. PP. 393-412. 
work, Dir Berufsureine, devotes a section to labor associations in Spain. The section is recommended by the officials of the Institute of Social Reforms. Reference nay be also nade to the chapter of the treatise of Gutiersez-Cancro (supra, p. 122) covering this subject.

\section{MISCELIANLOUS I.ABOR LAWS}

A law to protect women and children in all industrial and connercial establishments, exeept agricult nial labor and work done at home, was passed March 13,1900 . Emile Chauvet discussed this law in his work on the legal protection of laborars in Spain. The law forbids the enployment of children under ten years of age except in some cases where the child can read and write, and linits the working hours for children nuder $1+$ years to six in industrial and eight in commereial establishments. In general it limits to cleven hours a diy the labor of all persons under the protection of the law. 'The provisions relating to women employees previous to, during, and inmediately following, maternity are greatly amplified by the law of Jamary 8, 1907. By royal decree of January 25, 1908 , some changes were nuale in the general law and a conplete list of employments forbidden to women and minors was published. In addition, three statutes (July 26, 1878 ; July 23,1903; and August 12,1904) designed to protect children may be noted. López Nuñez ${ }^{2}$ has published the best treatise on the protection of children. It emphasizes health and moral problems.

Another important step in the industrial laws of Spain was the Sunday rest law (Descanso dominical) of Mareh 3. 1904. No law has as yet been passed to limit the length of a day's work for artisans, but in 1902 a deeree of the Minister of Finance fixed eight hours as the day's work in the state mine's and factories, with provisions for paynent for overtine.

Numerous other laws have been enacted in the field of social legislation, such as those governing apprenticeship, cooperation and enigration. Sone little adrance has been made

'Chauret, Finile. Ia protection légale des travailteurs en Espague. Paris, Soc, nouvelle de librairic (G. Bellins), roo3. 132 p.

" lópez Nuñez, Alvaro. La proteceión de la infancia en Fspaña. Matrid, F. Arias, 1908. $399 \mathrm{p}$. 
in technical and labor edueation, and in Valencia and Barcelona model lomes for workmen were established, in 1914. The Institute of Social Reforms ${ }^{1}$ published in 1910 a second edition of a collection of notes and bases for the draft of a law for workmen's housing. Reference las already been made (supra, p. 122) to the recent draft of a law governing the hours of employment of clerks in mereantile establishments. One of the most recent projects is the proposed law prohibiting all night work in bakeries. ${ }^{2}$

\section{IN'TERNATIONAI, I,AW \\ PUBL, INTERNATIONAL, LAW}

While works on public international law bear only a slight relation to Spanish municipal law, nevertheless many of them contain data on the international legal relations of Spain, and for that reason the most important works in this field may appropriately be mentioned.

The treaties of peace between Spain and other countries since the year 1590 are readily accessible. Abreu's ${ }^{3}$ compilation of treaties covering the years from 1590 to 1700 , in twelve volumes, was published during the middle of the eighteenth century. The treaties from 1700 to 1843 were collected by Cantillo ${ }^{4}$ in one large volume, and those from is 42 to 1868 by Janer. ${ }^{5}$ These were all published under the direction of the Department of State (Ministorio del Estado). The texts of the treaties from $183+$ to 1907 are printed in Olivart's 6 collec-

1 Instituto re reformas sociales. Preparación de las bases para un proyecto de ley de casas para obreros casas baratas. 2 led. Madrid, Suc de M. Minuesa de los Ríns, rgio. $2 \mathrm{~V}$.

${ }^{2}$ Instituto de reformas sociales. Preparación de las bases para un proyecto de ley prohibiendo el trabajo noctumo en la industria de la panificación. Madrid, Suc. de M. Minuesa de los Ríos, rorz. $287 \mathrm{p}$.

${ }^{3}$ Abren y Bertodano, José Antonio de. Colección de los tratados de paz . Madrid, D. Peralta, H. Martin and J. de Zuñiga, I7401752. I2 V.

4 Cantillo, Alejandro del. Tratados, convenios y declaraciones de paz y comctcio. Madrid, Alegria y Charlain, 18.43. 908 p.

${ }^{5}$ Janer, I'lorencio. Tratados de España, docnmentos internationales ... Madrid, M. Ginesta, r860. 550 p.

- Olivart, Marqués de. Colceción de tratados, convenios, y documentos internacionales. . Malrid, Proureso (also Rev de derecho int. y polit. exterior) 1800-1008. $17 \mathrm{v}$. 
tion of treaties, agreenents and other international documents to which Spain has been a party. Documents since 1908 may be found in the periodical of international law edited by the same publicist (infra, p. r 33). A fragnentary collection ${ }^{1}$ of treaties was published by the government in $180 \mathrm{~s}$, in three volunes. The treaties concluded between the United States and Spain are printed in Malloy's "Treaties, conventions," etc., 1910, II, pages $1640-1723$.

Labra, ${ }^{2}$ in his work on the Institute of International Law, includes (pp. 179-187) a bibliography of modern Spanish works on international and public law. Olivart ${ }^{3}$ compiled a general bibliography of international law which is really a eatalogue of his former private library, now owned by Harvard University.

Although in recent years Spain has produced no great works or treatises on international law, her early writers, especially those of the sixteenth century, were preeminent among the world's great jurists and international lawyers. Their works are still cited. Francisco de Vitoria in his Relectiones thcologicae (supra, p. 20) diseusses various questions relating to rights of war. The influence of Vitoria is discussed at length in the historical sketch of "Spanish jurists and the science of the law of nations" by Nys in the 1912 Revue de droit international et de legislation comparé, pages $360-387,494-524,614-642$. The article presents an acconnt of the early Spanish international lawyers up to the sixtcenth century. The important place of Vitoria in the history of international law is also attested by a recent monograph published by Abad. ${ }^{\prime}$ Soto ${ }^{5}$ in his work, De justitia ct jure, takes up the questions of his day and defends Charles $V$ in some of his policies. A Jesuit, Suárez, in his De legitus ac Dco leqislator (supra, p. 20) deals with the law of races in general.

${ }^{1}$ Colección de los tratados de paz, alianza, emmercio, ete. Madrid, Real, 1 796-1801. $3 \mathrm{v}$.

${ }^{2}$ Labra y Cadrana, Rafael $M$. de. El instituto de derecho internacional. Madrid, Alfredo Alonso, 1907. $57+\mathrm{p}$.

ativart, Marqués de. Bibliographie du droit international. 2d ed. Paris, A. Pedone, ig05-1910. 1,280 p.

* Abad y Cavia, I*. El dominieo español liray Franciseo de Vitoria $y$ los principios modernos sobre el derecho de la guerra. Madricl. Hijos de R. Alvarez, in I. $5+1$.

"Soto, Domingo. De justitia et jure. Salamanca, Joannes Maria y Ger ranova, 1566.895 p. 
An early work in the literature of international law, the accessibility of which has recently been enhanced by its translation into English, is the treatise by Baltasar de Ayala ${ }^{1}$ on the rights of war and military discipline. Ayala occupied a position somewhat analogous to that of Judge Advocate General to the armies of Philip II of Spain. The recent English edition under the anspices of the Carnegie Institute has brought to its service, as editor, the late John Westlake, who, in a brilliant introduction, contributed to the work one of his last literary efforts.

Reference may also be made to three works of the eighteent h century. In $17+6 \mathrm{Abreu}^{2}$ published a legal-political treatise on prize law. The work was twice translated into French and enioyed considerable authority. A work by Olmeda," "the elements of the public law of peace and war" is not withont some interest at the present time. A history of intermational law was published in 1776 by Marin, who is possibly more profound than Almeda.

It is worthy of note that the most original Spanish work in the field of international law, published during the nineteenth century, came from the pen of a woman, Concepcion Arenal. ${ }^{5}$ The work has been criticized as being somewhat sentimental and theoretical, but its originality and value have never been doubled. The leading treatise of the nineteenth century, a work of considerable reputation to-day, was published by Riquelme ${ }^{6}$ in 1849 . Landa's ${ }^{7}$ work on the laws of war from

'Ayala, Raltasar de. De jure et officiis belli. Madrid, H, Ortega ! Holredes Harra, I:93. $383 \mathrm{p}$.

Same. Classics of International law. Ayala. Trans. by J. B. Bate. Edited by Ioln Westlake. Waslington, Carnegie Institute, 1912 $2 \mathrm{~V}$.

2 Abrcu y Bertodano, IF́liz José. Tratado juridico político sobre las presas del mar. Cadiz, Real de Marina, i746. 335 ]).

${ }^{3}$ Olmteda y León, José. Élementos del derecho público de la paz y de la gnerra. Madrid, Viuda de Manuel Fernández, r $77 \mathrm{r} .2 \mathrm{v}$

4 Marín y Mendoza, Joaquin. Historia del derecho natural y de gentes. Madrid, $1 ;-6$.

5 Arenal, Concepción. Ensayo sobre el derecho de gentes. Madrid, Rev. de legislación, $1870.309 \mathrm{p}$.

${ }^{6}$ Riquelme, Antonio. Elementos de derecho internacional públien. Madrid, Santiago Sanque, $1 S_{49} .2 \mathrm{r}$

${ }^{7}$ Lintuda, Nicasia. Lil dercelo de la guerra conforme a lia noral. 3rd ed Pomplona, J. Sorda, $1877 . \quad 336 \mathrm{p}$. 
a moral point of view is also considered one of the best productions of his time. The third edition appeared in 1877 .

The best modern general treatise for reference purjoses, although somewhat lacking in originality, is that of (Mivart, the fourth edition of which appeared in 1904 in fonr volumes. An abridged edition in one volume was published in 1006 . The furists "lorres Campos ${ }^{2}$ and Gestoso ${ }^{3}$ lave each publisliced elemental treatises on international law. Fernández Prida, professor of international law in the University of Madrid, has published a useful collection of studies dealing with topies of both public and private international law.

A treatise on international maritine law, published b: Negrin, ${ }^{5}$ in 1888 , is considered authoritative to-day. A suicle for the Spatish diplomat by Castro ${ }^{B}$ contains some interesting discussions of legal topies. A periodical or review of international law (Reissta de devecho international y politica exterion) was established at Malrid in rog by Olivart, who assumed the position of editor and director, assisted by llerreros. The numbers ajpear irregularly and devote considerable space to the reprinting of texts of treaties, ete.

To supply the deficiency of works on international law by Spanish authors, translations of foreign tratises, steh as those by Fiore, Bluntschli, ete, with Spanish notes are currently used.

$$
\text { CUNFL,TCT OF LAWS }
$$

As in the case of all continental civil codes, allhongh with less minuteness than in the Cerman on Swiss codes, many pro-

1 Olivart, Marqués de. Tratado de derecho internacional publico. ${ }^{\text {th }}$ cd. Madrid, V. Suarez, $1903^{-1904}+\mathrm{r}$.

Same. Derecho internacional público. 5th ed. Compendiada. Madrid, Rev, de derecho internacional y polit. Ext., 1906. +t 6 p.

2 Torres Campos, Manuel. Elementos de derecho internacional público. $2 d$ ed. Madrid, Fernándo Fé, r904. $501 \mathrm{p}$.

${ }^{3}$ Gestuso $y^{*}$ Acostal, Luis. Curso elemental de derecho internacional e histórica de los tratados. $2 \mathrm{~d}$ cd. Valencia, Donnencelı, Ino\%. $2 \mathrm{v}$.

${ }^{4}$ Fennández I'rida, Joanquin. Estudios de derecho internacional público y privado. Madrid, V. Suarez, rgor. 31 r p.

segrín, lgnacio de. Tratado de derceho internacional maríinio. ad ed. Madrid, Vinda é hijos de Abienzo, $188_{3}$. $5 \% 41$ ).

"Castro y Casalciz. A. Cinia práctica del diplomático español. Madrid. Lil Correo, $1830.2 \mathrm{r}$. 
visions on the conflict of laws or private international law are incorporated in the Spanish civil code. These provisions were discussed by Eugène Audinet in an article published in volume is of Clunet (1891), pages 1106-1129. A brief discussion, in pamphlet form, of questions relating to the conflict of laws in matters of the fanily (familia) and successions under the code was made in 1908 by Rubira. ${ }^{1}$

The most complete and useful Spanish treatise on private international law cante from the pen of Prof. Conde $y$ Luque, Rector of the University of Madrid. The second edition was published in 1910. Another useful, but considerably nore elementary, work is the recently (1913) revised edition of Torres Campos ${ }^{3}$ book. Gestoso ${ }^{4}$ has recently (1913) published an extensive treatise, covering all branches of the subject.

Attention may be directed to the introductory work of Prof. Fernández Prida ${ }^{5}$ of the University of Madrid. The collection of studies by the same aut hor (supra, p. 133) contains three interesting monographs on topics in private international law. It is interesting to note that despite the existence of numerous treatises and works by Spaniards on the conflict of laws, translations of foreign works, notably fione and Asser, are employed to a great extent by Spanish lawyers.

The legal position and condition of foreigners in Spain were discussed in some old French treatises now ont of date. 'Torres Campos in the 18 th volume of Clunet (1891), pages $108-119$, published a sketch of the history of the position occupied by foreigners in Spanish legislation. Two works of some in1portance on questions of nationality and the law of aliens were

${ }^{1}$ Rubira Abarca, Alfredo. El derecho internacional privado y la jurisprudencia española en materia de familia $y$ sucesiones. Madrid, Hijos de Reus, igo8. Pamplilct.

${ }^{2}$ Concle y Luque, Rafael. Derecho internacional privado. $2 \mathrm{~d}$ ed. Madrid, V. Suarez, I9Io. $2 \mathrm{v}$.

${ }^{3}$ Torres Campos, Manuel. Elementos de derecho internacional privado.

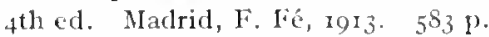

* Gestoso y Acosta, Luis. Nuevo tratado de derecho internacional privado ... civil, procesal, penal y mercantil. Valencia, Domenech, sgl3. Srop.

${ }^{5}$ Fernández Prida, Joaquin. Dereclo internacional privado. Valladolid, M. de la Cuesta, $1890.312 \mathrm{p}$. 
published in 1901 by Castro,' and by Concle y Luque,? respectively. A brief account of the position of foreign corporations in Spain, by Francisco lastres, appeared in volume 33 of Clunet (1906), pages $273-27$ S.

The subject of extradition is discussed in a snall work by Gascón, ${ }^{3}$ and in a more extended treat ise by Walls ${ }^{4}$ in which special attention is given to procedure. The extradition treaty between the United States and Spain now in force is that conduded June 15, 1904. It may be found in Malloy's Treaties, conventions, etc., 1910, volunle II, pages 1712-1718.

lixpulsion, from the point of view of international law and of Spanish legislation, is discussed in a work by Castro, ${ }^{5}$ published in 1896 and condensed in his Estudios (supra), at pages $165^{-169}$. Torres Campos in volume 29 (1902), pages 291-295, and Iastres in volume 37 of Clunet (1910), pages $369-374$, each contributed articles in French on the right of expussion of foreigners in Spain.

Justice Cobian of the Spanish Supreme Court prepaned an intesesting account of the law relating to the execution of foreign judgnnents in Spain and Spanish-Anerican countries for the kevista de leqislacion. Each conntry receives individual treatment. 'The article was translated and rearranged by Ardenne de Tizac, and may be found in volumes 39 and 40 of Clunet (1912), 1913, pages 1059-1071, 89-101.

It may here he noted that the important decisions of Spanisl conrts on questions relating to private interuational law are reported at regular intervals in the periodical of Clunet.

${ }^{1}$ Castro y Casaleiz, Antonio de. Fistudios de derecho internacional privado. Conflictos de nacionalidad. Condición de extranjero. Madrid, F. lié, rgoo. 303 p.

2 Conde y Iuque, Rafael. Oficios de dereeho internacional privado. Nacionalidad. Situación del extranjcro. Madrid, Hijos de Alvárez, 1901. $577 \mathrm{p}$.

${ }^{3}$ Gascón y Marin, José. La extradición ante cl derecho internacional. Zaragoza, 'Turmo, I 806 . I $61 \mathrm{P}$.

* Walls y Merino, Manuel. Ixtradición y el procedimiento judicial internacional en İspaña. Madrid, V. Suarez, soo5. 512 p.

"Castro y Casalciz, Antomio de. Fl derecho de expulsión ante el derechn internacional y la legislación española. Ed. oficial. Madrid, 1806. 
COLONIAI, LAW.

After the aequisition by Spain of her American colonies, the first step towards devising a means for their government was the establishment of the Casa de la contratacion at Seville in 1503. Its powers were described by Bernard Moses before the American Historical Association in 1894 (Annual Report (1894), pp. 93-123). The Casa de la contratación was later stubordinated to the Conncil of the Indies, established in 1524 . Spanish-America was governed from Spain by this Couneil, under atthority and direction of the king, and its powers were greatly inereased by succeeding sovereigns. The administration of the laws in the colonies was under the charge of viceroys or captains-gencral. The viceroy, his powers, and the general adminsitration of the Spanish colonies, especially Mexico, in the eighteenth century were discussed by Donald E. Smith ${ }^{1}$ in a recent work (1913).

The office of adclantado was employed in mediaeval Spain and was extended in 1.97 to the American colonies where it became of some importance. Roscoe H. Hill of Columbia University has discussed this office at some length in the December (1913) issue of the Political science quarterly, volume 28, pages 646-668. Roscher in his Kolonien, Kolonial politik und A uswandorung (3rd ed., 1,eipzig, i 885) devotes a few sections to the Spanish colonial system. The work is interesting, but incomplete, and it is criticized in that the writer is not impartial in his views. Professor Boturne ${ }^{2}$ translated these sections into English with bibliographical notes.

The various laws enaeted in Spain for the government of the colonies were first collected and digested by order of Philip IV. An incomplete compilation was made in 166 I but the first "Recopilacion de Indias" 3 did not appear nntil 1680. A second edition of this collection or compilation was made

1 Smith, Donald Eugene. The viceroy of New Spain. Berkely, Univ. of Calif. Press, I9I3. 293 p.

"Roscher, Willelm. The spanisl colonial systenr. 'Translation by Fidward Gaylord Bourne. New York, H. Holt and Co., I904. 45 p.

${ }^{3}$ Recopilación de las leyes de los reinos de los Indias mandadas imprimer y publicar por la magistrat católica del Rey Don Carlos II. Madrid, I6So. $2 \mathrm{v}$. 
in 1756, a third in 1774 and a fourth in 1791. The last cdition, conveniently indexed, aspeared in $1 S_{+1}$, in fonr volmmes. It may be stated, however, that the ofder editions are more reliable. A chronulorical index ${ }^{2}$ of the Spanish colonial legislation, covering tle years 1680 to $18_{47}$, was publisherl in 1s 4 s. The Kecopilación de leyes de los rines de Indias or, as it is commonly called, the Recopilación de Indias was a digest of the laws, royal orders, etc., issued from tine to tine by the Spanisl government for the government of the colonies, and was not a complete code. Hence, it was necessary to supplement it by the general and common law of spain. Thus, the civil law of Spain becane the fundanemal law of Anerica, but there was a restrietion in lle kecopilacion de Indias (1. fo, $t i, b .2)$ to the effect that no law or statute cuacterl in spain shonld be obligatory in America muless expressly conmanded by the Conncil of the Indies. An old work by Murillo, in latin, riscusses the manner in which the Spanish laws should be received in the Indies. The work deals prinurily with canon law, but secular law on this point is diseussed. Walton in lis "(ivil law" (supra, p. 36) gives a brief acconnt of the laws of the Indies (pl). $518-526$ )

The leyes de Indias, or the old colonial laws, were collected in 1889 , in thirteen volumes, by Guardia." The work was undertaken at the request of and by support of the Spanish government. Rodriguez San Pedro, assisted hy several eollaborators, compiled in 1869 the ult ramarine legislation of the nineteenth century into 16 volumes, with annotations. In continuation of these two works a compilation of the lewislation and decrees extended to the colonies, and indicial

${ }^{1}$ Recopilación de leyes de los ruinos de los Indias. . 5th cel. Madrid, Boix, isf 1 . $\mathrm{V}$.

andice cromologion de la serie de leyes, ete. . gobierno y administractión de las provincias de Indias descle 1080 loasta 18.4 . Marlrid, IS.48.

3 Murillo Velarde, Petrus. Curstus juris camonici hispani el indici . . Matriti, Fernández, $174.3 .2 \mathrm{v}$

Same. 3 d. ed. Matriti, Rniz, r701. 2v,

t Guardia, Miguel de la. I as leyes de Indias con las posteriores a entat código, vigentes luoy. . Madriel, Nuñez, 188 o. I3

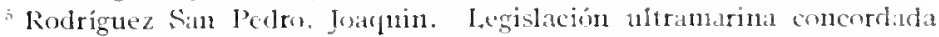
y anotada. Con la collaboración de Antonio diemández Chorot, Eduardo y Antonio Piera, y Manuel Gonzalez Junguitu. Madrid, Viota, Cubas y Vicente, 1805-I809. Io $\mathrm{r}$. 
decisions rendered in colonial litigation, was published by Fernández Martin, ${ }^{1}$ in io small volumes.

There are 1 o treatises or expositions, complete and satisfactory, on colonial law, for two reasons-first, all authors in the past have treated only of a few topies and, secondly, there are so many unedited docunnents lying in the archives of the Council of the Indies in Seville. The most interesting and useful exposition of the laws of the Indies is that by Solozano, a nuember of the Consejo de Indias. The first edition appeared in Latin. There are various Spanish editions of equal value. A treatise discussing the laws anterior to the Recopilacion de Indius was published by Maurtua ${ }^{3}$ in 1906 . The reviews of the work have been extrenely farorable. A valuable historical account of the inperial legislation in the tultramarine provinces was begun in 1893 by Fabié, ${ }^{4}$ but only the first volume, covering the early years, has appeared. Labra ${ }^{5}$ in I 897 published a discussion of the important questions at that time before Spain, in relation to the law and administration of its colonies. A work of especial interest to the United States is the "Ultrantarime political reform" "by the same writer. The public and administrative laws of the colonies are disctissed, with an extensive treatment of the international aspect of the Cuban question in 1900 . The law of 1891 in regard to

1 Fernandez Martin, Manuel. Compilación legislativa del gobiemo y administractión civil de ultranar arreglada en virtud de reales órdenes de 8 de febrero de is\$6 y 29 de cnero de 1888 [y 27 de mayo de 1893]. Madrid, Lucas Polo, $1888-\mathbf{1} 894$. Io v.

2 Solórzano Pereira, Juan de. Disputationem de Indiarum iure sive de iusta Indiasum occidentalium inquisitione, etc. Matriti, F. Martinez, $1629-39.2 \mathrm{r}$.

(Ist Spanish edition): Politica indiana. Madrid, Diego Diaz de la Carrera, $1648.2 \mathrm{v}$.

2d ed. Ambereg, H. \& C. Vicsdussen, r $703.536 \mathrm{p}$.

${ }^{3}$ Maurtua, Victor Mantuel. Antecedentes de la recopilación de Indias -. Madrid, B. Rodriguez, Igo6. $245 \mathrm{p}$.

${ }^{4}$ Fabié y Éscudero, Antonio María. Ị̇nsayo histórico de la legislación española en sus cstados de ultramar. Madrid, Sucesores de Rivadeneyra, i $896.336 \mathrm{p}$.

${ }^{5}$ Labra y Cadrana, Rafacl María de. Cuestiones palpitantes de política. derecho $y$ administración. Discursos por . . Madrid, A. Alonso, I897. $502 \mathrm{p}$.

* Labra y Cadrana, Rafael Maria de. La reforma politica de ultramar. Discursus de ... I809-1900. Madrid, A. Alonso, Igor. 1,116 p. 
the arministration of justice in the Spanish colonies, with appendices of related matters, has been translated by the United States War Department (supra, p. 87). The introduction to the work by Sanchez de Ocaña is also translated.

A collection of the laws, ordinanees and regulations adopted from time to time by the Government of Spain, relating to the disposition of public lands in her colonies, was compiled in 1828 by Joseph .I. White, ${ }^{1}$ at the direction of the Attorney General of the United States, on the occasion of the settement of land titles in Florida. Spanish public land laws in the Philippines, with an account of their history up to 1898 , we compiled by the Forestry Bureau in 1901 .

Spanish law in the British Empire was diseussed briefly by Charles 4 . Reis in an article in the January, 191.4, Journal of the Society of Comparative Legislation, pages $24-33$.

\section{CANON I.AW}

Canon law, which during the Hiddle Ages was al "common law" for the whole of Europe, has exerted a lasting influence upon continental law and has played an important part in the development of Spanish secular law. A translation of the section of Brissaud's "History of French private law" dealing with the sources and general literature of canon law is included as part $I X$ of the first volume of the Continental legal history series. Reig ${ }^{3}$ in 1904 published a work on the influence of the canon law in Spain. An early work on the institutions of canon law by Gómez Salazar' is worthy of mention. The same author has also edited a manual." Gol-

'Housc Ex. Doc. I2I, 2oth Cong., 2nd scss. Private land clains in Florida, by Joseph M. White. Washington, Gales and Seaton, I828. $277 \mathrm{P}$.

${ }^{2}$ Spanish public land laws in the Philippines and their history to August $I_{3}, I_{9} 8$, translated and compiled in the Forestry bureau under the direction, of George P. Alern. Washington, Crovernment Printing Office, 1901. 6I $\mathrm{p}$.

${ }^{3}$ Reig y Casanovas, Furique. Cuestiones canónicas. El derecho canónico en España, y su influencia. Toledo, Rodríguez, 1904. $3231^{3}$.

4 Gómez Salazar, Francisen. Institnciones de derecho canónico. 3rrl ed. Madrid, Hermanus de Minor, i $890.3 \mathrm{v}$.

${ }^{6}$ Gómez Salazar, Francisco. Manual eclesiástico. Madrid, A. Gómez Fuentenebro, 18;2. I $v$. 
mayo's" "Institutions of canon law" las passed through seven editions, the last in 1 \$96.

There are two useful treatises on ecclesiastical law in general, with special reference to Spanish law, a briefer one by Manjón ${ }^{2}$ and a five volume work of Morales. ${ }^{3}$ A prize work on the Spanish law in its relations with the church was published in 1902 by López Peláez." The same author made another contribution a few years later in the form of "ecclesiastical studies". In r 914 , the first volume of a new work by Campos ${ }^{6}$ made its appearance.

An interesting article by a Spanish professor appeared in 191 in the North American Review, volume 193, pages $256-270$, on the present conflict between church and state in Spain. The religious orders and corporations were diseussed from a legal point of view by Buitrago ${ }^{7}$ in 1901 . A short article by Andre "l'ridon appeared in the fort $y$-fourtl rolume (1910) of the Forum, pages 272-279, in which the political relations with the Vatiean and the present symptoms of an economic readjustment are discussed. The legal situation of the Roman Catholic church in the different states of Europe and America lias been discussed by Giron. ${ }^{8}$ He has also published a discussion of the concordat between the Queen and the Holy See. ${ }^{9}$

${ }^{1}$ Colmayo, Pedro Renito. Institneiones del derecho eanónico. 7 thed. Mladrid, Gabriel Sánehez, r $\$ 96.2 \mathrm{v}$.

" 11 an jón, Andreu. Derceho eclesiástico general y español. $2 \mathrm{~d}$ ed. Madrid, Huérfanos, I $\delta g \mathrm{I} .2 \mathrm{v}$

${ }^{3}$ Mrorales y Alonso, Juan Pedro. Tratado de derecho eclesiástico general y particular de España. Madrid, Góngora, I\$83-92. 5 v.

"Lopez Peláez, Antolín. El derecho y la iglesia. Derecho usual. Madrid, Hijos de Gómez Fuentenebro, igrr. $55^{\circ} \mathrm{p}$.

${ }^{5}$ López Peláez, Antolin. Estudios canónicos. Barcelona, Gustavo Gili, I $906.1 \mathrm{r}$.

${ }^{6}$ Campos y Pulido, J. M. L.egislación y jurisprudencia canónica novísima y disciplina particular, de España. Madrid, Hijos de Reus, I9I4. $+7^{-8} \mathrm{P}$.

"Isuitrago y Hernández, Joaquin. Corporaciones religiosas . . Madrid, A. R. de Castroviejo, 1901. $4^{89} \mathrm{l}$.

"Cirón y Areas, Joaquin. I a situación jurídica de la iglesia católiea en los diversos estados de Europa y América. Madrid, V. Suarez, 1905. $379 \mathrm{p}$.

${ }^{9}$ Girón y Arcas, Joaquin. La reforma del concordato eclebrado entre el Santa Sede y la reina de España. Madrid, l'Suarez, rgoz. I v. 
A work published under anthority of the church and of special use for nucubers of the clergy and modern ceclesiastical tribunals is the treatise of Miracle de Carbonell.' 'This work contains directions and advice for the clergy in cases of marriage, wills, etc. The old question of pat ronage betweet the Pope and the Spanish kings has been thoroughly discussed in the work of Vazquez, which was awarded a prize offered by the Minister of State in 1882 , and in an older work by Más. ${ }^{3}$

Carlena ${ }^{*}$ publisled in 1892 a practical treatise on eclesiastical procedure in civil and erininal mat ters. The first volume of Góncz Salazar and la Finente's work on procedure appeared in a sccond cdition in 1 syo. It inchules matrinonial procedure. The same authors published a work on ecelesiast $i$ cal discipline or laws of conduct, ${ }^{6}$ supplementary to the proceeding. The proceedings of the Inquisition have been discussed in a work of Melgares Marin." The origin and ecclesiastical character of the institution, religions persecution, scandals of the inquisition, the priests, etc., are some of the interesting topies discussecl.

Two valuable monograpls on marriages and matrinony following the decree ne temore lave come from the pens of

${ }^{1}$ Miracle de Carboncll, Agustin. Fi parroco y al curial. Machid, Hijos de Reus, i90.4. $967 \mathrm{p}$.

"Vázquez y López Amor, Antonio. Examen listórico-legal del derecho de patronato de la corona de Espana sobre les lugares pios de Tierra Santi. Madrid, Hijos de Reus, 1882. 2 I 4 p.

${ }^{3}$ Más y Monzó, Felije. Patronato celesiástico de los reyes de Fispaña. Madrid, Hijos de Reus, $1871.258 \mathrm{p}$.

* Caderra y Eleta, losé. Tratado teórico-practico de precedimientos eclesiásticos en materia civil y criminal. Marlrid, 1.. Aguardo, $189 \mathrm{I}-1892.2 \mathrm{v}$.

${ }^{5}$ Gómez Salazar, Itrancisco and I, a liuente, Vicente de Tratado teóricopráetico de procedimientos eclesiásticos. ad ed. Tomo I, Procedimientos matrinoniales. Madrid, Gónez Fuentemebro, I89o. $688 \mathrm{p}$.

${ }^{6}$ Gómez Salazar, Firanciseo and I,a fiuente, Vicente de. Secciones de diseiplina eclesibstica $y$ suplenento al tratalo de procedimientos eclesiásticos. 5th ed. Madriđl, Gónez I'ucrntencbro, 189. 2 r.

- Melgares Marín, Julio. Procedinientos de la inquisicion. Madrid, L. P. Villavorde, $1886.2 \mathrm{v}$. 
Aquilar ${ }^{2}$ and I'erreres. ${ }^{2}$ The former's work has seen three, and the latter's five, editions. An interesting discussion by a prominent lawyer, Cabello, ${ }^{3}$ of the supreme power in the public law of the church mav also be mentioned.

'Aquilar Jiménez, I. Nueva legislación sobre esponsales y matrimonios. 3rd ed. Hadrid, Hijos de Reus, I909. $244 \mathrm{p}$.

${ }^{2}$ Ferreres. Juan 13. Los esponsales y el matrimonio, 5th ed. Madrid, Razón $y$ Fé, 19II. 460 p.

${ }^{3}$ Cabelle y Guillen de Tokdo, Alfonso. La soberanía o suprema potestad en el dereclo público de la iglesia. Madrid, Hijos de J. A. García, I89.5. $207 \mathrm{p}$. 


\section{GLOSSARY}

Abandono. Abandonment.

Alintestato. Intestate.

Abogado. Attoney at law, lawyer, barrister.

Abogado en cjercicio. Practieing attorney.

Abogado del estado. Attomey for state.

Abogado de oficio. Attorney apponted to plearl for poor litigants.

Abogar. To argue or plead a case.

Aborto. Abortion.

Alssolueión de posiciones. Answers to interrogaturies.

Acaparar. To eorner the market.

Acaparador. One who comers the market.

Aeción. A share of stoek, lawsuit.

Aceptacion. Acceptance.

Aeeptar una letra. Honor or aceept a lill.

Aelaración. Fixplanation, illustration.

Acomodación. Accomodation.

Acreedor escriturario. A creditor who proves his debt by means of a public notarial instrument.

Aereedor hipotecario. See hipoteca.

Acreedor refaccionario. A preference creditor. One who las advaneed money for building purposes.

Actuaciones. The records of pleadings of a case.

Aetuario. Judicial officer who authentieates all the documents in the suit.

A cuenta. On account, in part payment.

Acusación. Impeachment.

Acusar la rebeldia. To diselose resistance toorders of a judicial authoirty. Adelantado. A mediaeval Spanish officer formerly employed in the American colonies.

Arljudicación en pago. The appropriation on applieation that is nade judicially of the real or personal property of a debtor in favor of a ereditor in order to eover the anount due to lim.

Administracion. The direction, government and care which a man or corporation has of the property under lis charge of an inlieritance of a minor, of an insane person, of a prodigal, of an establishment or of an individual; so that every guardian, eurator or executor has an administration. Administration is in reality a power of attorney or mandate, and eonsequently produces the same obligations and rights as this contract.

Adulterio. Adultery.

Arlverteneia. Notice, remark, advice.

Agente. Agent.

Agente de cambios. 13ill-broker. 
Agotado. Out of print.

Albaceazgo. lixecutorship.

Alcabala. Fixcise or tax on sales.

Alcabala del viento. Duty paid by a visiting merchant.

Alcalde (of a twwn or city). Head of a district of a city. Tenicntes alcalles, all the alcaedes; alcalde mayor, president of the tenients alcalles.

Al contatro. for casli.

Alguacil. Bailiff, fowest officer in the seale of officials in the adruin istration of justice.

Alguacil mayor. Sheriff.

Alianza. Alliance.

Alistamiento. I,evy, conscription.

Alnuacén. Wirchouse.

Alnirantazgo. Court of admiralty jurisdiction.

Almojarifazgo. Duty on imports or exports.

Alzamiento, Naking a higher bid at an auction.

Allanamientus. Trespass.

Allanamiento de morada. lireach of the house or home.

Allanarse á la demanda. Admission by defendant of allegations in the plaintif's complaint.

Amenaza. Threat.

Amillaramiento. Assessnent of a tax.

Anortización. Mlortmain.

Anotacion preventiva. A preliminary and provisional entry of a clatm upon real property. Sce Brmoficio de inventario.

Anticipaciones. Advances.

Anticresia. Antichresis. An agreement by which the debtor gives to the creditor the income from the property which lie las pledged, in lien of the interest on his debt.

Añuario, Tear-bork.

Año económico. Fiscal year.

Aparcería. Partnerslip.

Apelación. Appeal to a higher court for reversal.

Apelacion desierta. Abandonment of an appeal after it is entered.

Apercibimiento. Order of a judge or court enforcible by contempt proceedings,

A plazos. On credit.

Apoderado. Attomey (agent).

Apremio. Sale of attached property to pay the decreed debt.

Aprendizaje. Apprenticeship.

Apuntamiento. Fixtract from the record.

Araneel. Fee, tariff.

Armiadil. Narz:

Arras. Property given by a man to a woman either before or after their marriage. It must not exceed one-tenth of what he possesses.

Arrendanientu, locise.

Arrendialor. lessor.

Arrendante, I,essor. 
Arrendatario. I,essee.

Asegurado. Insured.

Asegurador. Underwriter, insurer.

Aseguramiento. Insurance, seeurity.

Asesinato. Killing with premeditation, ete. Corresponds to our nurder in tlie first degree.

Asiento. Fintry (on records).

Asociación. An association (company).

Atentado. Criminal attenut.

Atribución. Prerogative.

Audiencia. Court of appeal, provincial eourt.

Autenticidid. Authenticity-act of authentication.

Auto. Decree or decision of a judicial body in regard to some question of fact, evidence or jurisdiction. Every jurlicial decision which is neither a final decision (sentencia) or decisions referring to matters of procedure (providencia).

Auto acordado. A decision rendered by a consejo or a superior court on some point applicable to its anthority to be observed as a precedent. Also in plural is used to denominate the decrees of the council of Castile that were embodied in the Nueva and also the Nozisima resopilarión.

Autor. Principal (in a erine), autlor.

Autorización. Anthorization.

Autos. Original file in the action.

Auxilio. Cooperation, aid, assistance.

Aval. Accommodation endorser.

Avaluo. Appraisement of property.

Aviso. A notice.

Ayuntamiento. Mumicipal government composed of a mayor and alderinen.

Balnearios. Public batlıs.

Bancarrota. Bankruptcy.

Bandera de paz. Flag of truce.

Bastanteo. Examination or impeachment by counsel of the authority or right, conferred on the solicitor, for bringing the action.

Beneficencia. Poor laws, clarity.

Beneficio de inventario. The provisional right which the heir has of remaining free from liability to pay the creditors of the deceased beyond the value of the inheritance.

Benefieios. Profits.

Bienes. Property in general.

Bienes gananciales. Property acquired by the husband and wife by a comnnon title during their marriage and while they live together, or whit the husband or wife or either of then during their marriage and living as one may acquire by purchase or by means of labor and industry, as also the fruits of the private property that each brings to the marringe.

Bienes nuebles. Personal estate.

$$
77: 31^{\circ}-15-10
$$




\section{46 GUIDE TO THE LAW OF SPAIN}

Bienes raices. Real estate.

Bienes reservables. The property that can not be alienated but must be reserved for certain relatives.

Higamia. Bigamy.

Billete. Ticket.

rillete de banco. Banknote.

Boletin oficial. Official gazette or bulletin of the province.

Bolsas de comereio. Commercial exchanges.

Buena fc. Bona ficles.

Bufete. lawyer's office, desk.

Cadastre. Official assessment of the quantity and value of the real property in any district, made for the purpose of justly apportioning the taxes payable un such property.

Cadena (perpetua, temporal). Confinement with chains worn at ankles and waist. Considered next to death penalty in severity.

Caducidad. lapse (of action or yroceedings); failure to take effect.

Cajero. Cashicr.

Calumnia. Ialse imputation of a erime, either oral or written, which was the cause of a prosecution, slander.

Cámara de compensación. Clearing house.

Cancelar. Cancellation, to cancel validly.

Capacidad. Capacity.

Capellania colativa. The capital and interest of a foundation that requires its possessor to be a clergyman.

Careo. Confrontation of the prosecuting witnesses by the accused for purpose of cross-examining them.

Cargador. Consignor.

Cargo. Office, burden.

Carta de fletamento. Charter-party.

Curta de naturalezi. Letters of naturalization.

Casación. Annulment or quashing of a judgment.

Caución. Bailbond or bail.

Caudal. Property, wealth, funds (plural).

Causa. A criminal suit or prosecution, consideration.

Causahabiente. Legal successor of a former litigant.

Cedente. Transferor.

Cédula. Order emanating from some superior tribunal, promulgated in the name and by the authority of the sovereign. A bond.

Cédula personal. Legal document or personal certificate every Spanish citizen must possess.

Cédula real. Royal letters patent.

Cencerrada. A disturbance of the peace in the form of mock serenades with horns and bells upon the marriages of widows or mismated cuuples.

Censatario. Payer of ground-rent, or one who pays an annuity out of his estate to another.

Censo. The contract whereby the right is acquired of receiving an annual pension on delivery of something. The right itself of receiving the pension. A perpetual annuity, or one for a tern of years. Ground rent. 
Censo de poblacion. Consus.

Censo eluctoral. I, ist of voters.

Censo consignativo. Consignative ground-rent; rents from one holding land of a debtor for bcinefit of ereditor.

Censo de por villa. Annuity for one or more lives.

Censo enfiténtico. Emplyteusis, a contract of a special nature in regard to use and oceupation of land.

Censo frumentario, Crain-rent.

Censo reservativo. Reservative ground-rent.

Censualista. An annuitant; receiver of a ground-rent.

Censuario. The person in whose favor an annuity is granted, or he who has the right to receive the annuity. (some writers use the word to signify the party who pays the annuity.)

Certeza. Certininty.

Cesión. Cession, transfer.

Cesionario. Transferce.

Cesion de bienes. Surrender of the estate of an insolvent debtor into the hands of his creditors.

Citación. Citation.

Citación de remate. Notice to debtor of intended sale of his goods to pay lis debts.

Ciudadano. Citizen.

Coacción. Act of compulsion.

Cobrar. To collect.

Cobro $\}$ Collection.

Código. Code.

Cohecho. Bribery.

Comercio. Commerce.

Comisión. Commission.

Comisionistat. A fictor, commission merchant.

Comisionista de garantía. Del credere factor.

Comiso. Every description of confiscation. The reversion of the useful ownership of an enfiteutic property to the direct owner in case of the party charged not paying him the tribute. Property confiscated is also styled comiso.

Comitente. The principal.

Compañia anónima. A limited stock company or business corporation. Compañia colectiva. Unlimited partnership.

Compañia de seguros. Insurance company:

Compañia en comandita. A Jimited partnership. A partnerslip where there are "silent" members who are only liable to the anount they invest.

Comparencia en juicio. Act of appearing before a judge and dlemanding justice.

Compendio. Summary, abridgment, compendium.

Compensación de crédito liquido. Set off producing effect of payment.

Competencia. Jurisdietion.

Competencia ilicita. Enfatir compctition. 


\section{48 GUIDE TO TIE LAW OF SPAIN}

Cómplice. Accomplice.

Compra. Purchase.

Compraventa. Bargain and sale.

Comprobación. Proof, comprobation.

Con arreglo. In conformity with.

Concejal. Member of a public board or city conncil.

Concejil. Referring or concerning to concejal.

Concejo. Civic body of a small town.

Concejo abicrto. Neeting of the inluabitants of a small town presided over by the mayor to deliberate upon public affairs.

Concurrencia. An equality of rights or privileges which several persons have over the same parcel of debtor's property.

Concurso. The suit instituted either by the debtor or by the creditors as to payment of debts. The meeting of creditors. A competition or contest.

Condición resolutoria. The condition which, on being fulfilled, produces the revocation or invalidation of the contract, and places matters in slatu quo.

Confianza. Confidence.

Confinamiento. Confinement, a species of banishment.

Congreso. Lower body of the Spanisli parliament or cortes.

Conocer. To take cognizance, to try a cause (by a court).

Conocimiento. Judicial notice, cognizance, bill of lading.

Consejo. Council.

Consejo de estado. A consultative body of persons chosen by the king to take cognizance of matters of the greatest interest to the government and administration of the kingdom, both home and foreign. Comncil of State.

Consentimiento. Assent, consent.

Considerandos. Paragraplis setting forth legal grounds on which a judgment is based.

Consignatario. Consignee.

Conspiración. Conspiracy.

Constitución. Constitution.

Consulaje. Fices paid to consuls by all merchant vessels.

Contenencia á la demanda. Demurrer.

Contestación á la demanda. Defendant's plea, or answer.

Contrabando. Smuggling.

Contratación. Trade, commerce.

Contrato. Contract.

Contribución. Tax.

Contribuyente. Taxpayer, contributor.

Convenio. Pact, agrcement, convention.

Conyuges. A married couplc, consorts, husband and wife.

Copia original. The first copy, grinted and signed by the identical notary who attested the original instrument.

Corona. Throne, crown.

Corporación. Corporation.

Corredor. Broker. 
Corredor de cambios. Fixchange broker.

Correduria. Brokerage.

Corregictor. Administrative liearl of a town, mayor. See alcalli.

Correo. Post, mail.

Correspondencia. Mail (correspondence).

Correspondiente indemuización. Due conpensation.

Cosa juzgada. Res judicata.

Costas. Costs.

Costumbre. Custom, duty.

Criminología. Criminology.

Cualificado. Qualified.

Cuasi contratos. Quasi contracts.

Cuenta. An account, reckoning, computation.

Cuenta-corriente. Current account.

Cucnta de resacar recambio. Return account.

Cuenta de venta. Account $\rightarrow$ sales.

Cuerpo del delito. Corpus delicti.

Culpable. Guilty.

Culto. Worship, religious belief (also culture).

Cumplimiento. Performance.

Curia. Ecclesiastical court, tribunal.

Curial. Member ecelesiastical court.

Cheque. Check.

Dar cuenta. To answer, to give account.

Dar fianza. To give bail or pledge, or earnest money in a trade.

Darfe. To attest, to certify.

Dataria. Datary, office of the chancery at Rome where the Pope's bulls are expedited.

Deber. Duty, obligation.

Deber (verb). To owe, ought.

Debido curso. Due course.

Declaración. Deposition.

Declinatoria. Plea to jurisdiction before the judge who has not jurisdiction in order for him to abstain and to send record to proper court.

Decreto. Order similar to cédula in ccelesiastical matters.

Dedicarse. To practice (a profession)

Defensi. Defensc.

Defraudaciones. Frauds.

Delincuente. Offender, criminal.

Delito. One of the two divisions of crimes. This is the greater and comprehends crimes dangerous to the person and property, violations of laws done intentionally. Iielony.

Delito consumado. Consummated crime.

Delito frustrado. Crime not consummated on account of a cause purcly independent of the will of the actor.

Delito de incendiar. Arson.

Demanda. The written declaration or complaint in pleading.

Denencia. Lunacy.

Derecho. Riglit, law in general, borly of law. 
Derecho administrativo. Law of administration of public business and the govemment.

Derecho civil. Civil law.

Derecho canónico. Ecclesiastical or canon law.

Derecho comín. The civil or general law of a place, as distinguished from the particular or municipal law of a province, district, or city, or from any special or privileged law, as the military, ecclesiastical and commercial.

Derecho eontencioso-administrativo. See jurisdicción.

Derecho de gentes. Natural law, such as prevailed among foreign nations, as contrasted with the Roman law. International law.

Derecho foral. Local statutory law. Special law of certain provinces. Derecho internacional privado. Conflict of laws.

Derecho internacional público. Intemational law.

Derecho no escrito. Unwritten law, established custom.

Dereclo militar. Military law.

Derecho mercantil. Commercial law.

Derecho penal. Criminal law.

Derecho político. Political seience (in broad sense). Constitutional law (in the restricted sense).

Derecho procesal. Procedural law.

Derecho real. The inlierent right to a thing, so that it is not extinguished by the death of him who possesses it, but which always exists therein into whosoever hands the thing may be transferred.

Derogación. Repeal.

Desahucio. Ejectment of tenant at expiration of term.

Desamortizar. To disentail, to break an entail.

Descuento. Discount.

Desembolso. Disbursement.

Desempeño. Performance, act of redeening a pledge, exereise (of a profession).

Desistimiento. Voluntary abandonment of the litigation.

Destierro. Exile, judicial banishment.

Detención. The arrest.

Detencion ilegal. False imprisonment.

Detener. To arrest.

Deuda. Debt.

Deudor. Obligor, debtor.

Día de irabajo. Working-day.

Diario de avisos. Official gazette of the locality or district.

Diccionario. Dietionary, encyclopedia.

Dictamen pericial. Opinion of expert witness in a trial.

Diligencia. Execution or performance of an order of the judge.

Dinero. Money.

Diputado. Representative in the Cortes elected by the people in the electoral districts in which spain is divided (as distinguished from a senator).

Discordia. Disagreement of the judges.

Disintar. To gain advantage, reap benefits, enjoy. 
Divorcio. A divorce.

Doctrina legal. Rules of law which the Supreme Court draws ap in its judgments in order to found its decrees

Documental. Documentary.

Documento. Instrument, document.

Docnmento negociable. Negotiable instrument.

Domicitiado. Person who, thongl not sui juris, resides permanently in and forms part of the house of a recino.

Domicilio. Permanent dwelling place of a recino and domiciliado, domicile.

Dominio. Ownerslip.

Dominio directo. The right which a man has of concurring in the disposal of a thing the produce whereof he has assigned; or of receiving a certain pension or annual tribute in acknowledgement of $\mathrm{his}_{\mathrm{s}}$ seigniorial right or superiority over the property. The right of superiority of a real estate without the right of usefui ownerslip.

Dominio supremo. Eminent domain.

Dominio util. The right of receiving all the fruits of a thing upon paying a contribution or tribute to him who preserves therein the direct ownership.

Dotación. Revenue.

Duclo. Duelling.

Dúplica. Rejoinder.

Edieto. Public order of a judge or court issued on default of a party or to notify a large number of people of an auction sale, etc.

Efecto. Eiffect, consequence.

Efecto devolutivo. The cognizance which by means of an appeal the superior judge takes of the decrees of the inferior court without suspending their execution, but referring the nuch for reconsideration.

Efecto suspensivo. The cognizance which in virtuc of an appeal, the superior Judge takes of the decrees of the inferior, suspending their execution.

Efcetos. Effects, novables, drafts, assets.

Efectos en cartera. Bills in hand.

Efectos públicos. Public seeurities.

Efectos á pagar. Bills payable.

Efectos á recibir. Bills receivable.

Ejecución. Execution.

Ejecutoria. Public document in which a final judgment is transeribed. Final decree.

Ejercer. To practice (a profession).

Ejército. Army.

Eimbargo. Attachment of debtor's property, sequestration, embargo.

Embajador. Embassador

Emitir. To issue.

Empate. Tie vote.

Emplazamiento. Sunmons of the judge directed to the defondant th appear and answer the elaim.

limpleado. Employee. 
Enajenación. Alienation.

Enajenar. To alienate, transfer.

Eneargado de negoeios. Chargé d'affaires; agent, attorney (Mex.).

Eneubridor. Accessory after the fact, concealer, ete.

Endosante. Indorser.

Endosatario. Indorsce.

Endoso. Indorsement.

Enfiteusis. Lease.

Enjuiciamiento. Procedure.

Enmienda. The correction of some error or defect. The satisfaction and payment of losses incurred. The revocation or correction of some sentence.

Entrega. Delivery.

Entre sí. Inter se.

Equipaje. Baggage.

Error. Mistake.

Es bastante. "It is sufficient," formula used in certifying to sufficiency.

Escalamiento. Entry into a building by sneaking into it or climbing the walls as opposed to burglarious entry.

Escribano. Clerk of eourt of first instance.

Escrito. Writing.

Escritor. Writer, author.

Escritura pública. Docunsent exeeuted with legal formality before a notary:

Espera. Extension of time in a deht, acljournnent.

Fistado. State, commonwealth.

Estado seglar. Layman, secular or lay rank.

Estatuto. Statute law. Flural used to name a clarter or by-laws of a company, etc.

Estafa. Swindle.

Estelionato. A fraud, generally applied to the fratudulent sale or mortgage of property previously solil or mortgaged.

Estrago. Malicious destruction of property.

Estupro. Seduction, constupration.

Fivicción. Eviction, implierl warranty of title in sales.

Examen. Examination.

Excepción. Defense, plea.

Excepeión delatoria. Dilatnry plea.

Excepeión perentoria. Demurrer.

Excusion. The exhaustion of the judicial or extrajudicial proceedings so as to have recovered all the value of the debtor's property. Also the liquidation of the debtor's estate for benefit of his creditors.

Exhorto. Letters requisitorial sent by one judge to another

Expedidor. Shipper, consignor.

Expendición. Sale.

Expropiado. Dispossessed.

Expropiación forzosa. Dispossession from ownership for public use or by eminent domain.

Fixtinción. Exxtinction. 
Extradición Fxtradition.

Extranjero. A foreigner (different country). See Forastero.

Extrañamiento. Fixulsion.

Extravio. Deviation.

Factor. Manager, factor.

Fadiga. The right possessed by the seignior in the direct ownerslip whenever the thing bailed or leased is alienated, so as to retain it for the sum that the purcliaser offers.

Fallo. Symonymous with auto or sentencia, but especially the part of the latter in which the judge or court actually renders its decree or decides the questions in dispute is called the fallo. So called because that part by law must begin with the word fallo.

Falta. Division of lesser crimes, misdemeanor.

Falta de aceptación. Nonacceptance.

Falta de pago. Nonpayment.

Falsificación. Counterfeiting, also forgery.

Fazaira. Sentence given in a suit.

Feclia. Date.

Fechado. Dated.

Feligresia. District of a parish, its inhabitants.

Fianza. Bond (criminal law), security.

Fideicomisario. A devisee or legatee who is to deliver the devise or legacy at some future time to another; also a legatee beneficially interested in property left to another in trust; also an executor; cestui que trust.

Fideicomiso. Trust, the res of the trust, feoffnent to use.

Fiduciario. Legatee, trustee or the licir of a legatee trustee.

Ficldad. Sequestration, security.

Filosofía. Philosoplyy.

Firna. Signature, partnerslip.

Firma entera. The complete signature comprising both the christian and sumame.

Fiscal. State's attorney, prosecutor, etc.

Fisealia. Business or profession of a fiscal.

Fletamento. Afreightment.

Fonento. Development, patronage.

Fomento, ministerio de. Department of public works, education, commerce, agriculture and manufactures in Spain.

Fondos. Funds.

Foral. (Used as adjective, with nouns like "law," "government," ete.) Special rights or the law of a province or towtl which was originally granted by the king in their clarters. Local or provincial law.

Forastero. Foreign as between different provinces of sane country. See extranjoro.

Formación de cansa. Process of law.

Frutos en specie. Finngible goods.

Fuera. Out, outside of.

Fuero. Statutory law, compilation of laws, jurisdiction of a court. 
Fuerza mayor. Vis major (as "Act of God").

Funciones fiscales. Duties of the solicitors for the state in the superior and supreme courts in the interests of the public treasury and other public causes.

Fundación. Revenue established for any purpose, a foundation.

Gaceta de Madrid. Official gazette (daily) of the Spanish government. Contains texts of new laws, orders, etc. of the decisions of the Supreme Court.

Gananciales. See bienes gananciales.

Garantía. Warranty.

Garrote. The screw or apparatus used in Spain for the execution of criminals.

Gasto. Expenditure, eost.

Gastos. Expenses, disbursements, charges.

Giro. Draft note, bill, ete. (general word).

Gobierno. The government.

Golfo. Vagabond, ontlaw, term applied to the degencrate scum of a city.

Gravamen. Lien, encumbrance, mortgage, charge.

Haberes. Weaith.

Hábil (dia). Day on which the courts sit.

Habilitación del letrado. The formal admission by the State of a lawyer to practice in the courts.

Habitante. Resident, but not necessarily citizen.

Hacer fe. To acknowledge, to certify. The sufficiency of any statenent or writing, as proof, is acknowledged when it is said that it makes faith.

Hacienrla. Public property of all kinds, land, also public revenue.

Hacienda pública. Public treasury, funanees.

Heredero. Heir.

Heredero legal. Heir at law.

Heredero fiduciario. Heir trustee.

Hereneia. Inheritanee.

Hijo. Child or other descendant, son.

Hipoteca. Nortgage, mortgage contract.

Hológrafo (also ológrafo). Will or last testament of a person wholly written in his own hand, signed and dated by testator.

Hombre bueno. Arbitrator in the attempt to arbitrate legal disputes before suit is actualiy begun.

Homicidio. Manslaugliter.

Honorario. Fee.

Huelga, A strikc, lockout.

Hurto. Theft, thievery.

Imprudencia. Negligence.

Impuesto. Tax, impost.

Incendio preneditado. Arson.

Incidente. Ouestion that arises between the parties in litigation during the course of the prineipal action. Interlocutory application.

Incoar un juicio. To bring suit. 
Incommunicado. Prisoner in the solitary continement in which the is placed aiter arrest.

Indefensión. Unfaimess; lack of defense caused by fraud.

Indenuización. Danages recovered by plaintiff.

Indultar. To pardun, to exempt.

Indlistrial. Person engaged in industries.

Infanticidio. Infanticide.

Informa. Pleading, report.

Informe pericial. Expert evidence.

Infracción. Violation, breach.

Inhábil (dia). The day on which the courts do not sit, vaeation day.

Inhabilitación. Disability, disqualification.

Inhibitoria. Motion before a judge having jurisdietion for renoval of cause from court not having jurisdiction.

Inhumación. Intermcut.

Injuria. Slander and libel, ontrage.

Inseripción. Record as public record for mortgages, ete.

Interdicción civil. Deprival of all rights under the eivil code over the family or property of the condemned.

interdicto de rccourar. Summary proceeding to recover possession of eonverted chattel.

Interés. Interest.

Interés legal. Interest fixed by law.

Interés convencion:l. Stipulated interest.

Jomal diario. Daily wages.

Jubilación. Retirement of an offiecr or employee of the government on a pension or reduced pay on arrival at certain age.

Juego. Gambling, game.

Judicatura. Judiciary.

Juez. A Judge.

Juez arbitrato. Arbitrator, umpire.

Juez de letras (juez letrado). A justice of the peace of a small district, who, being a counsellor at law, has more authority in eertain cases than other justices.

Juez instructor. IExamining nagistrate in criminal prosecutions. Investigation carricd on while the aecused is in solitary confinement.

Juez de primera instancia. Trial judge.

Juez ponente. The judge who draws up in writing the opinion of the court, himself and colleagues.

Juicio. A suit, act of judging, judgment, proceeding.

Junta. Council, board, meeting, convention.

Junta de comercio. Board of trade.

Junta de gobicrno. Fxecutive committee.

Jurado. Jury.

Juranento. Oath.

Juramento asertorio. Declaratory oath.

Juranento decisorio. Oath taken by deponent when party secking his deposition admits whatever siad as incontrovertible evidence.

Juramento falso. Perjury. 
Juramento indecisorio. Oath that can only hurt the deponent.

Jurisdicción. Jurisdiction.

Jurisdicción contencioso-administrativo. Jurisdiction in which are decidcd qucstions in litigation arising between the administration acting within its jurisdiction and individuals who consider their rights damaged by the act thereof.

Jurisprudencia. Court decisions, "judge made" law, legal science.

Jurista. Jurist.

Jurisconsulto. Jurist.

Justicia. Justice.

Juzgado. Court of first instance.

Legitima. That part (two-thirds) of the paternal or maternal estate of which the testator can not disinherit his children without legal cause.

Legítimo. Legitimate.

Legislación. Legislation.

Lego. A novice. Laybrother in monastery.

Lesa majestad. Leze-majesty or high treason.

Lesión. Personal injury inflicted by violence.

Letra de cambio. Bill of exchange.

Letrado. Lawyer.

Levantamiento. Revocation, withdrawal.

Ley. Statute, act.

I,ibcración. Discharge.

Libertad. Liberty.

Librado. Drawee.

Librador. Drawer.

licensia. Permission.

Licito. Licit, lawful.

Litigar. To suc, to litigate.

Litis pendencia. Lis pendens.

Loco. Lunatic, insane person.

Magistrado. Magistrate.

Mala fe. Bad faith.

Malicia. Malice.

Malversación. Maladministration.

Mancebo. Assistant.

Mancomunadamente. Jointly, by common consent.

Mandamiento. Order by judge to subordinate officer.

Maruinación. Artifice.

Marca (de fábrica). Trade mark.

Masa de la quiebra. The total assets of bankrupt estate liahle to debts.

Matrimonio. Marriage.

Natriz (escritura). The original instrument or document, stub of check book.

Mayor edad. Najority, full age.

Mayoría. Majority.

Media firma. Surname.

Medida. Measure. 
Mejora. Advantage, or the portion of the estate reserved as legitima by law which the parent or testator may appoint to a particular or child descendant.

Mcnor edad. Minority, infancy.

Ministro de hacienda. The Secretary of the Treasury.

Moneda. Coins, metallic money.

Morada. Dwelling-liouse.

Mostrarse parte. To intervene or take part voluntarily in an official procecling.

Mluerte. Deatl.

Mujer casada. Married woman.

Multa. Fine, forfeit.

Municipio. Municipality.

Nacer. To be born.

Nato. Used with and to mean $c x$ officio.

Naturaleza. Nationality, naturilization.

Negado. Incapable, unfit.

Negar. To deny, to refute an accusation.

Negligencia. Negligence.

Nombrado. Nominec.

Nombrador. Nominator.

Nombramiento. Appointment.

Nominador. Nominator.

Nominilla. Warrant or certificate enabling a pensioner of an office to draw his dues.

Nomino. Nominee.

Nomógrafo. Nonrographer, a writer on litws.

Norma. Standard.

Notario. Notary:

Noto. Bastard, illegitimate.

Novación. Novation.

Novel. New, inexperienced.

Nulo. Invalid, null.

Numulario. A banker.

Nunciatura. Office or hotse of a muncio.

Nuncio. Envoy or anbassador from the Pope to Roman Catholic princes.

Nuncupativo. Nuncupative.

Obligación. Bond; also a contract of obligation.

Obligación de probar. Burden of proof.

Obligado. Obligation.

Obrero. Workman.

Oferta. Tender.

Oficina de correos. Post-office.

Oficina de patentes. Patent office.

Oido. A hearing.

Ológrafo. See holoyrafo.

Ordenamiento. Orders eminating from the king and differing from cédula only in form and in mode of promulgation.

Otorgar. To execute an instrument, to anthorize. 
Otorgante. Grantor, party who signs and executes any notarial instrument.

Otrosí, "Horeover." Technical word used to introduce a paragraph containing matter different from the prineipal object of the document.

Pacto. Agreement, pact.

Pagaré. Promissory note.

Pago. Payment.

Pago parcial. Installment.

Parafernales (bienes). Parapherna. Goods brought by wife to husl rand over and above her dowry.

Parcería. See Aparcerin.

Parricidio. Parricide. Includes all degrees of consanguinity as well as the relation of husband and wife.

l'árroco. Rector or incumbent of a parish, a priest.

Parte beneficiada. Accommodated party.

Parte por aconodación. Accmmodation party.

Particular. Private person.

Partido. One of the judicial districts into which the provinees are divided; an agreement.

Parto. Childbirth.

Patente de invención. Patent.

Patria potestad. Parental power.

Patronato. Patronage, patronship.

Patrono. Nlaster, employer.

Paz. Peace, truce.

Peculio. Estate or property which a child possesses as separated from the property of his father.

Pena. Punishment, penalty.

Pensión. Rent or annual tribute imposed on landed estate. Pension.

Perito. An expert.

Perjuicio. Prejudice.

Perjuicio (sin). Without prejulice.

Perjurio. Perjury.

Personarse en juicio. Aplearance of defendant by at torney in court.

Personas juridicas. Juridical persons. Corporations, associations and institutions of public interest.

Pesquisa. Inquisition, name for old form of prosecution, search, investigation.

Petición. Pctition.

Picota. Pillory.

Piratería. Piracy.

Pleiteante. Litigant.

Pleitear. To sue, to go to court.

Pleito. Civil lawsnit.

Plus minusve. More or less.

Plus petición. Excessive relief or danages.

Puder. Power of attorney.

Poligamia. Polygany.

Politica. "The art of governing the people." 
Policía. Police.

Portador. Bearer (as negotiable instrument payable to).

Porteador. Carrier.

Posadero. Innkeper.

Posición. An interrogatory (in writing).

Postura. Offer or bid at an anction.

Práctio. Practice.

Pragmatica. See ordenamiento.

Predio. An inheritance, land or immovable possession.

Predio dominante. Land or property to which there belongs an casement over other property.

Predio seviente. Lind or estate owning an colsentent to a dominatut estatc. Servient estate.

I'risión. Imprisonment, confinement, seizure.

Irejudicial. Requiring a previous juticial hecision before the fomal sentence.

Prelación. I'reference.

Prenda. Pledge.

Preseripción. Preseription, statute of lintititins.

Presentación. Presentment.

Presidio. Punishment by hard labor, jail.

Presidio mayor. Hajor and minor arrest. Confinement for periods pro-

Presidio menor. $\}$ vided in the penal eode at hard labor.

Prestamista. Pawnbroker.

Préstamo á la gruesa. Bottonry loan.

Presunción. Presumption (legal or of fact).

Presunto. Suspreeted.

Presupnesto. Budget of state, estimate.

Previsión. Old-age pension.

Previsto. Provided (for or by).

Probatoria. Time allowed for producing evidence.

Precesado. The accused, defendant.

Procurador. Attorney, attorney at law, solicitor.

Procurador fiscal. Public attorney named by the king to promote and defend in the supreme and superior courts the interests of the exehequer and other public causes.

Pródigo. A man who by sentence of a judge has bern deprived of the free administration of his property by reason of his leading a dissipated life. He is put on the same footing with a lmatic and disqualified from doing legal acts.

Producto. Proceeds.

Profanos. Persons ontside of legal profession, laynem.

Promotor fiseal. The minister appointed to promote the observance of penal laws, or he who in a criminal case is named by the judge to prepare and support the acensation against the criminal.

Prontuario. Compendium or digest.

Propietario. Proprietor.

Propriedad inmueble. Real property.

Propriedad mueble. Personial property. 
Protesta. Protest (of a bill).

Protocolo. A file or archive of original instruments left with the notary, the parties laving certified copies only. A registry.

Protutor. Vigilant guardian, one appointed to see that the guardian does his duty and also to represent the ward in and out of court when his interests are adverse to those of the guardian.

Providencia. Judicial decision referring to inatters of procedure.

Proyecto. Rill, schene, design, plan.

Proyceto de ley. Bill (introduced in legislative body), a proposed form for a statute.

Prueba. Evidence, proof.

Pucblo. Town, people, nation.

Puerto. Port.

Quiebra. Bankrujtey.

Quebrado. Bankrupt.

Quebrado alzado. A bankrupt who has fled from his business address to avoid creditors.

Quebrantamiento de forma. Tiolation of form or of a rule of procedure. Querella. The indictment or information in criminal investigations.

Quinto. The one-fifth part of an estate wlich a man can dispose of to strangers by his will.

Quita. Partial release by creditor.

Ramo scparado. Separate filc.

Raptu. Abduction.

Ratero. Pickpocket.

Ratificación. Ratification.

Razún social. Firm name or the distinctive name of unlimited and limited partnerships.

Real cédula. Royal dispateh signed by the king and issued by some superior tribunal, wherein some favor is granted or some interlocutory decree is made.

Rebeldia. Default, contempt. (Used in loth eivil and eriminal matters.)

Rebelión. Rebellion.

Recibo. Receipt.

Recomendatario. Referee in case of need (used in negotiable instruruents).

Reconvención. Counterclaim.

Recopilación. Digest, connjilation.

Recurso. Appeal.

Recusación. Challenge, exception.

Recmbolso. Reimbursement.

Refrendar. To conntersign.

Regente. The chief justice of a body composed of several tribunals in combination.

Regidor. Alderman of a city.

Réginen. Government, management.

Registro. Ixamination, act of searching, also a register.

Registro civil. The civil registry. 
Reglamento. Written instruction given by a competent authority withont the cubservance of any peeuliar form; provision for carrying into execution a statute alrealdy enacted.

Reintegro. Repayment.

Reivindicación. Replevin, recovery.

Reivindicar. Toreplevy, to recover.

Relator. Person appointed and deputed in every appeal court to make a summary of facts of the various cases for the jundge.

Remate. Auction, highest bid at auction.

Remisión. Remitting.

Remolque. Towage.

Renuncil. Waiver.

Reo. Offender, criminal.

Reportimiento. Allotment, division.

Repertorio. Index, digest.

Repetición. Claim, action for accounting.

Réplica. Replication in pleading.

Reponerse. To be annulled.

Reprensión. Reprimand (public).

Represalia. Reprisal.

Requerimiento. A demand.

Resarcimiento. Indemnity damages, compensation.

Resguardo. A receipt, collateral security.

Resideneia. Residence, alsu sumctinies means place where one lives with certain constaney.

Residente. Resident. Refers popularly to botls a ancio and domiciliado.

Resolución. Decision, resolution.

Responsabilidarl. I,iability,

Retracto. Right of replevying ur recovering at thing sold to another.

Resultandos. The setting furth of the facts forming the basis of the judicial decision.

Revisión. Review.

Revocar. To revoke.

Ricgo. Irrigation.

Rifa, Isttery.

Ritorno. Renvoi.

Robo. Relbery and includes burglary.

Rúbrica. A mark or fluturish uswally placed under one's signature as an added obstacle to forgery. [It is not the signature.]

Sacar testimonio. To make a certificd copy.

Salario. Wage, carnings.

Salario medio diario. Arerage, daity earnings.

Sal vaguardia, P'rotection.

Sal voconducto. Jicense or pernission.

Sancamiento. Security, indemnification. Also in administrative law, drainage.

Sano de juicio. Purfectly sound in mind.

Sedición. Sedition.

$77 \cdot 31^{\circ}-15-11$ 
Seguro. Insurance.

Seguro dotal. Endowment insurance.

Seguro sobre vida. Life insurance.

Seguro contra incendio. Fire insurance.

Seguro contra accidentes (or) percances. Accident insurance.

Sello. Seal.

Senado. Senate.

Senador. Senator.

Sentencia. Final judicial decision.

Sentencia absolutoria. Judgment where request demanded is refused.

Sentencia condenatoria. Decision in which something is commanded to be done or enjoined.

Sentencia firme. An irrevocalle judgnent or decision.

Señoraje or señoreaje. Seigniorage.

Señorio. Seiguiory.

Servidumbre. Easement both personal and real.

Sindico. Assignee, receiver.

Sin perjuicio. Without prejudice.

Sisa. Tixeise.

Sobreseimiento. Dismissal, discontinuance (of legal proceedings).

Socio. Shareholder, a partner, nember of a club, etc.

Solidariamente. Severally.

Subasta. Judicial sale of goods by public auction.

Súbdito. Subject of a country.

Subsidio. Subsidy.

Suceso incierto. Contingency.

Sucesor inmediato. The heir presumptive, the next succeeding.

Sucldo. Salary, pay (not "wages").

Suma. Sum.

Sumario. Preliminary investigation in criminal suits, similar to our secret investigations by the grand jury. Preparation for trial.

Sumariamente. Summarily.

Suplicatorio. Letters rogatory, or a writ or any legal instrument sent in the king's name by a tribunal or judge to another of equal authority that they may attend to what is solicited.

Suposición. Bogus representation.

Suspensión. Removal or suspension (from oflice).

Sustracción. Abduction, pick pocket or purse snatching.

Tabernero. Saloonkeeper or tivernkeeper.

Tablón de edictos. Official bulletin board in the courthouse for advertising notices.

Tacha. Incapacity.

Talón. Check, conpon, receipt, 1,inl, etc.

Talonario. A conpon or clueck-book.

Talón de transporte. Bill of lading.

Tanteo. Agreement or right (o) scll or buy at same price bid for by others at auction.

Tenedor. Holder.

Tener tacla. To be legally incapable. 
Tentativat, Attempt.

Terecría. Interlocutory procecding. Arbitration,

Tercin. The third part of an estate a testator can dispose of as he pleases when he leaves no deseendants, only ascendants.

Términos de gracia. bays of grace.

Territorio. Territury.

Tesorería. Treasury.

Tesorero. Treasurct.

Testamento, A will.

Testigo. Witness.

Testimonio. Testimony.

Título. Title.

Tontina. Tontine, annuity insurance.

Trabajo. Work, labor.

Traducción. Translation.

Traición. Treason.

Tramitación del incidente. Interlocutory proceeding.

Trámite. Judicial process.

Transacción. Contract, compromise, transaction.

Transeunte. Every person living in a place not a vecino or a dominciliado, transient.

Transgresión. Infringement.

Transporte de viajeros. Carriage of passengers.

Tratado. Treaty, treatise.

Tribunal. Court.

Tribunal de cucntas. Fixchequer.

Tribunal supremo. Supreme court.

Tutela. Guardianslip.

Tutor. Guardian.

Uso. Usatge.

Usurpación. Usurpation.

Vitlor. Vilue.

Vecindad. Residence, right acquired by resicling in a place given by law.

Vecino. Native Spaniard, sui juris, hatbitually and permanently residing in a place.

Vencimiento. Naturity (of a bill, sometimes "vencimiento de plizo."

Vender. To scll.

Venta. Salc.

Vinculacion. Entail, act of cntailing.

Vincular. To entail an estate.

Violación. Rape.

Visar. To mark "approved."

Visto bucno. The natk or formula "approved."

Vitalicio. During life.

Vitalieista. An annuitant or persen with an income for life.

Viuda. Widow.

Voto. Viste.

Yusinin. Order, precept. 



\section{INDEX}

Abad, 131.

Abellu:

Administración municipal, 114.

Arriendos y prestamos, for.

Beneficiencia, $\mathrm{s} \neq 0$

Cont ribución territorial, i ig.

I) recho administ rativo, 11 .

Derecho de cazo, 116 .

Lil cosisultor, $\mathrm{J} 8$.

Exprupriacion forzosa, 58 .

Impuesto, II

Minas, 117 .

Provincial y municipal, 13 .

Regist ro civil, 54.

Abreu:

I'resas del mar, $\mathrm{r}_{32}$.

'I ratades de pas, 530.

Absence (Bk. I, Civ. Corle), $4^{6}$

Absolutism and democracy, 25

Academia real de jurisprudencia $y^{\prime}$

legislación Catálogo. 9.

Accession (Bk. II, Civ. Code), 46.

Accidents, 125 ff.

Accounting, 68 .

Acts of commerce, $6 \mathrm{~g}$ ff.

Adelantado, ${ }^{3} 6$

Administrators, $5 \mathrm{~s}$.

Administrative law, niff:

I.lections, 115

Iunting and fishing, ir

Mines, Ir6.

Municipal and provincial, 113 .

Poor laws, i19.

Public finance, $1 \mathrm{~L} 8$.

Waters, is

Admiralt $y, 7 \gamma$ ff

Admiralty courts, 78 .

Ardoption (Bk. I, Civ. Code), 46

A.lverse prossession (Bk. II, Civ. Corde), 46.

Agacino, 27.

Agency (Bk. IV. Civ. Code), 4\%.

Agency, mercantile, 70 .

A suifera de Paz, gq.

Alarcỏn, 10.

Alaric, Code of, $2 \%$.

Alas, 26 .

Albo, 108.

Aleatory contracts (Bk, IV, Civ. Code), 4 . Aleu:

Aguas, 1 it 6 .

Diccionario, 10, 11 .
Alfaro, 89.

Alfonso X, 30 .

Aliens, $134 \mathrm{ff}$.

Allgemcine bibliographie, 8 .

Alonso Martinez, 40.

Altamira:

Continental 1aw, 8,36 .

Cuestiones de historia, 29.

Cuestiones [reliminares, $37,44$.

Derecho consuctudinario, 45 .

Literature on legal history, 36

Mctodo positivo, 45.

Teacling of legal history, 19.

Alvarado, 21.

Alvarez del Manzano:

Códigos de comercio, 68.

Derecho inercantil. 68.

Amat, 9 .

Ann.11, 43.

Andren, 15 .

A nigulo, 53.

Antequera. 55.

Anuario de legislacion 5 jurisprudencia, $r$ :

Aparici, 55.

Apprenticeship, 129.

A quilar, 142.

Arabic conquest, 29.

Aragonès, 61.

A ramburu, 107

Arbitration:

Civil suits, 84 .

Strikes, $127 \mathrm{ff}$.

A ree, 54 .

Ardenue de Tizac, 135.

Arenal:

Beneficiencia, sos.

Derecho de gentes, 1,52 .

Jurisprudencia, 20, 128.

A revalo, =o

Argolla, 92.

Arinas, 90.

A rrazola, 16

A rriaga, 79.

Asser, 134.

Asso:

Fuero viejo y ot ros códigos. 30, 32.

Institutes, 50

Associations (13k. I, Civ. Cude), $4 \%$.

Associations, mercantile (Bk. 11, Com.

Comle), $72 \mathrm{fj}$.

Audinct, ${ }_{3} .1$. 
Aunatell $\mathrm{T}$ usquets, 125.

Autos acordados, 3 .

Aval, 76 .

Average, 77.

Ayala, 21, 131 .

Ayllon, $; 8$.

Azcárate:

L:studios, 24 .

Historia de derecho de propiedat, 5.4 .

Legislaciön comparada, 24

Self-government, 11 I.

Baluies, 22.

Bank, Mortgage, 72

Bank of Spain, 64, 71.

Banking law, $7 \mathbf{f f}$.

Bankruptey (Bk. IV, Com. Code), 64.65. 79 If.

Banks (Bk. II, Com. Code), 65.

Bar Associations, 19.

Catalogues of lihraries, 8,9 .

Barrachina:

Derecbo foral, 4.

Derecho hipotacario, 02 .

Barrio, 67.

Barriobero:

Juris, $\mathbf{7}$.

l'ráctica forense, e, 0,99

Bembo, Max, 108

Benefit societies, 127 .

Benito:

Cámaras de comercio, $8_{3}$

I)erecho mercautil, 60 .

I,et ra de cambio, 76 .

Mandato mercantil,

Suciedades mercantiles, 73 .

Tribunales de comercio, 82 .

Barnaldo de Quirós:

Ierecho usual, 8,18, r 21 .

Theories of criminality, 102, 206.

Various, 108.

Beme convention, 55 .

Bibliography, ; ff.

Bills and notes (Bk. II, Com. Code), 65, 70 II.

Bills of ladiug, it

Blanco Constans, 68 .

Blanco de la Viña, ro4.

Blas:

Derecho civil Aragones, 42.

Municipal y Provincial, 113 .

Blustschli, 133 .

Boards of trade, 68 , 70 ff.

Bolsas de comercio, $70 \pi$.

Bonel, 44.

Bonilia, 68.

Borchard:

Bihliograpby, s.

Indemnity for errors of criminal justice, 103 .
Busco, 107

Bottoury, 77

Btsundry lines (Bk. If, Civ. Cinde), th.

Bourbons, 34 .

Bonrie, I 30

Brauchitsch, 36 .

Bravo, J., 94

Bravo Molto:

Conmunicaciones, 75 .

Ley del jurado, soo.

Organizacion judicidi, $x$.

Breviary, 27 .

Brissatd, I39.

Broca, 4.3.

Broker, maritime, 79 .

Brokers, ;o.

Brussels conventions, is.

Buit rago, 1 \%o.

Bntint. 51.

Buylla, i22.

Caballero y Montes, 8 .

Cabarris, 22.

Cabello:

Leyes de minas, 117

Soberauia, 142

Cabrerizo, 105 -

Cadalso:

I)iccionario, 94

Penitenciarios, 108.

Cadena, $1+1$.

Calabuig, 51 .

Calderón:

Filosofia, 24.

Yonados, 24.

Prolegómenos, 24.

Calyo, 49.

Címaras de comercio, $82 \mathrm{ff}$.

Campomanes, 21 .

Campos, 840 .

Canals, 110

Canon law, 139 ff.

Cantillo, I 30.

Capderille, $7 x$.

Capital muishment, 102.

Cardenas, 52 .

Carpena, 107

Carpentier, 56 .

Carrera, 117 .

Carreras, 69.

Carricts (Bk, II, Com. Curle), $65_{1}, 23 \mathrm{ff}$

Casa de la Cuntratación, 136 .

Castejonn, 43 .

Castillejo. 59 .

Castillo, $5^{6}$

Castro:

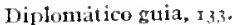

Expulsión, 135.

Nacionalidad, 135

Catali, 125. 
Cablllor, 21

Cersos, roo.

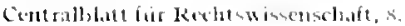

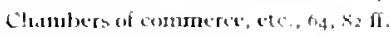

Clo,ij)idlo ( Fiarcial, 37.

('huluet, ing.

Cherble, 7 is

Child labor law $w 29$ fi.

Cival Coule:

commentaries, toff

contents. as.

liclitions, 4 s.

For,1 systems, 4:

1 instory, $3.8 \AA$

ludiviclual parts, s. ff

Relited subjects, $5=\pi$

Tratnslutions, 4 r.

Treatises, 50.

Clearing Houses, $\mathrm{n}_{4}, 72$

Clemente de Ijiego:

Apuntes de derecho civil, 51,59 .

I erecho usual, x, I 121 .

Revista, $1 \%$.

Transmibilidlad de obligucioncs, 59 .

Cluntet, ${ }_{35}$.

Colitin, 135 .

Cinle of Alaric, :

Cude commission, 39 .

Cindex legum, zs.

Cuinage, ris.

Culeyiu de notariados, sin.

Colegiess de abugados, 8,9, t9.

Collisions, $\pi T$.

Colmteiro, 110

Colonitl law, ${ }_{3} 6$.

Colmuich, $\mathrm{z}^{3}$.

cimas:

J royecto de refurma, so.

Revision del códino civil, 49.

Comision de reformas sociales, 120.

Commandite company, $7,3 \mathrm{ft}$.

Commerce (Bk. I. Conn. Code), 64.

conmmercial assucioltions, is if

Commercial curle.

Contents, 44.

Ceneral literiture,

Commentaries, om.

Eiditions, tri.

Indivilual parts, fo ff.

Relatcd subjects, og ff.

Translutions, os.

Treatises, 08.

History, 63.

Commercist consress, 82,83 .

Cummereial courts, $s_{1}$ ff.

Commercial luws of the world, The, fi.q, er. $8 \%, 125$.

Commercial percons (13k. I, Com. Cule), th.

commercial tresties, 8.3.
Commuision, corle, 39.

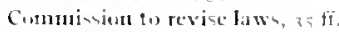

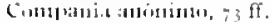

Compuniat enlectiva, $7=$ ff.

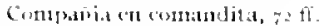

Comparative low, 24 ff

Comparative Iaw Bulletin:

Bislingr,ully, \&,

J.engilatim, Is.

Cumpradition act, 123 ff.

Concurrence (Bk. IV, Civ, Cenle), as.

Coneley loncue:

Deterhen int priviulo, 13.

Nacientalinglut. 135.

Conditionil se'tlence, 102.

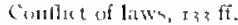

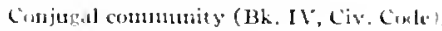
47.

Conrat (Colun), 27 .

Consejo de fumili.1, 5 = ff.

Conseju real de Castilla, i2.

Consejo supremo de guerria $y$ marina, so 4.

Constitutiondlaw, rog fi.

Constituiuntal mowement, 22.

Consular law, ;o.

Contentious-administrative jurisliction, 13, 88, r $3=$

Contentions jurisdiction, \& 4 ff.

Continent.1 legal history series, 36.

Contracts (Bk, IV, Civ. Cosle; Bk. II Com. Corte), 47,59 ff., 64, 69.

Cuoper, 8 .

Copyrights, $55 \mathrm{ff}$.

Curolen, 43.

Corporate agrements (Bk. II, Com. Code), 04.

Corporations (Bk. I. Civ. Code), 4r, o.s.

Corporation, business (Bk. It, Com. Cunde), 72 ff.

Curreo, 74,75

Costa:

Derecho consuctudinario, 45.

Esstudios, 24 .

Hecho juritien, 2:

Jgnotalucia de dereclow, 2s.

Lihert.ul civil, 42.

Municipall, 113.

Nutarialo, 90.

Vicla de dercelio, 24

Lints, s, at $\mathrm{ft}$.

Comert reperts, 12 0

Cints, si, ff.

Contrts, whumist rative, 88

Courts, incluntrial, 127.

Lourts, slilitars, 10, ff

Courts, municipd, as.

Courts, mival, $103 \pi$.

Erediturs, 0.8, iofi.

Conmint l.1w, y: ff 
Criminal law, military, 103 ff.

Criminal law reforms, 92, $106 \mathrm{ff}$.

Criminal procedure, 97 .

Criminology, 106.

Cuello, 96 .

Curry, III

Customary law, $42 \mathrm{ff}$.

Fato:

Giorgi, 59.

Jurisprudencia, $14,15$.

Debates in Senado, so.

Inclearde, r24.

be L,con, 47 .

Delitos, 93 .

lhepieges, 98 , ror.

I leposit (Bk. Ir: Civ. Code), 4\%.

Derecho foral, 33, $42 \mathrm{ft}$.

Dercche politico, $109 \mathrm{ff}$.

Descent of property' (Bk. III, Civ. Code), $46.58 \mathrm{fI}$.

nesertion of children, 96

Desigus, 56 .

Diaz de Mlotitalvo, zo fi.

Diaz Moreno, 62

Dictionaries, $15 \mathrm{ft}$

Diez Finriquez, 52

Inivarce (Bk. I, Civ. Code), ath.

Irodd, rog.

Donicile (Bk. I, Civ. Conle), tho

Donuinguez-Alfotso, 99.

I) nonoso Cortes, 22

Dorado Monteso:

Antropologia crimind, ro6.

Bases para derecho ncual, ion.

criminologia, 10:-

Eil derecho, 25.

Nucvo derecho penal, 25.

Nuevos derroteros penales, rob.

Psi cologia, 107.

Valor social de leyes, 25.

Dramatic works, 55 .

Du Bor:s, 92.

Due compensation, 57.

Durán y' Bas, 43.

Eascruents (Bk. II, Civ. Code), $4^{\text {to }}$

Etcclesiastical law, I39 ff.

Education, legal, I\%.

Elections, 115 .

Financipation (Bk. I, Civ. Code), 46.

Eiminent domain. $57 \mathrm{ff}$, 112 .

Fimphytensis, 60 .

Employers' liability act, $123 \mathrm{ff}$.

Foncyclopedias, $15 \mathrm{ff}$.

Encyclopedists, French, 21.

Eitutailment of estates, 5.4 .

Escostura:

Guia notarial, 90

Lcgislacion lipotecaria, 612 .

lescriche, is.

1:smein, 99.
Especulo (Espejo), El., 3r.

Espiga, 39 .

Espiritu, 66

Estascin:

Accidentes de trabajo, I25.

Aval, 77 .

Cuentas corrientas, zo.

Derecho ind ustrial, 56 .

Derccho maritimo, 78 .

Institutiones, 68.

Jurisprudencia mercantil, 6 .

Los Seguros. 76 .

Suciedades mercantiles, 73 .

Suspensiones de pagos, 80 .

Tiajante de connercio, zo.

Lurie, $2 ;$ ff.

Evidence, $8 ; f f ., 9 ;, 100$.

Executors, 58 .

Expert testimouy, 100

Expropriation, forcible, 5 ;

Extradition, 97, 135.

Fabick, 13 s

Factors, 69, 70.

I'alcón, 4

Faltas, 93.

Family council ( $\mathrm{Bh}$. I, Cir. Corle), $46,52 \mathrm{ff}$.

Farms, loans on, 62

Fres, 9r ff.:

Court, 84 .

Mortgage, $6 i$.

Notary, 84 .

Felonies, 93 .

Fenuásdez Gincr, 54.

Fernández Martin, $1_{3}$ ?

Finnández Prida:

Derecho int privalo, 134 .

Estudios, 133 .

Ficrreiro Lago, 52

Ferteres, I42,

Ferri, 105.

Ferrocarriles, $; 3$ ff.

Filiation (Bk, I, Civ. Corle), 46, $52 \mathrm{ff}$

Fiore, 133,134 .

Fishing laws, $11 \%$.

Florez Est rada, 22 .

Floridablanca, 22.

Foral law, $33,42 \mathrm{ff}$.

Foreign corporations, 135

Foreigu litigauts, 91, 92.

Foreiners, ${ }_{34}$ fi.

Fotos, 60.

Forroella, 4..

Forun judicum, 28.

Foucher, 66.

Foyé:

Caminos de hierra, is

Contrato de transperte, 75.

Franco y Lopez, dz.

Fraternal or sanizations, 120 
Fuero jnzgo, $28 \mathrm{\pi}$., 35

Iincro real, 30, 35 .

Fineroviejo, 30, 35 .

Fin/er-1/entan, 16

Gaceta de Madrid, ro, $x_{3}$

Galindez de Carvajol, 33.

Galindo, 6z.

Gallost ra, 89 .

Game laws, 156

Garcés, 7t.

Garcia Croyena, 39.

Crateia Herretos, 59.

García Mloreno:

Củdigo civil, 48 .

Cỏdigu de comercio, 07 .

1 ustituciones politicas. 17 .

Garcia Ronicro, 10r.

Gascin:

Fixtradicion, I35.

Servicios publicos, its

Geucral works, 15 ff.

Germanic influence, $27 \mathrm{ft}$.

Gestoso:

Derectos int., 133

berecho int. privado, 13.

Gifts (Bk. IIl. Civ, CudIc), $4^{\text {th }}$

Gil Maestre, 108.

Gil y Pablos, 72

Gil y Robles:

Absolut ismo, 25.

Derccho politico, 25, 110.

Actodologia juridica, 25 .

Giner de los Rios:

Estudios, 23, 1 и.

Filosolia, 24

La persona sucial, 23.

Prolegimenos, 24.

Gincés de Sepulveda, 2 r.

Giorgi, 59 .

Giralt, 115 .

Clossary, 143

Gmelin, nis.

Gexlincz, $-\pi$

Golmayo, 1.40.

Gonnez Chaix, 82.

Gomez Hertcro, I2.

Gomez Salazar

Derecho canónico, 139.

Procedimientos ecclesiasticos, 1.43 .

Gongora, 9, I8.

Gomzaticz, A., 109.

Gouzảlez de Alba, 10z.

González Alvárez, 75, 89.

Gonzale Cedron. iss.

González de las Cuevas, 75.

Gunzälcz Hontoria, 50.

Conzálcz de Linares, 45

Gonciles Maroto:

Pesca, 116 .

T'rihuuales de antrind, 78.
González Nandin, 103

Concilcz Rebollar, 125

Contétlez Revilla:

Derecho mereantil, 69

Hipoteca naval, $z s$.

Manual naval, 78 .

Gorosacal, 39.

Goths, 27 ff.

Gracian, 2I.

Grain, 61.

Grand jury, tor.

Groizard. 95.

Ground rents, to

Gual Villalbi, 6o.

Guaratty (Bk. II, Conn. Code), 65.

Guardia, 13 .

Guardianship (Bk. I, Civ. Cods), $46,52 \mathrm{ff}$.

Girticreze-Cañas, só.

Gutierrez lemindez, 92.

Guitierrez, Firancisco, 5.

Gutiérsez-Gancro, 122, 129.

Gutiérrez-Jinlenez, ss.

Habeas corpus, 10?.

Habitation (Bk, 11. Civ, Colk), 46.

Huciencla priblica, its fi.

Iracnel. 27.

Handelsgesctze des lirdballs, 65.

If apsburg period, 34.

Hartwig, 93

Harvey, 8 -

Hermur Espitosa, i:

I Iernández Jinteño, 1 18.

Hersero Martinez, 99.

Il idalgo García, 95.

Hijos de Reus, 9. IR.

Hill, 136 .

Hinojosa:

Estudios, 37.

Cemmanische element, 27.

Historia general, 37 .

Influencia, 108 .

Hipoteca, to ff.

Hipoteca, naval, 64, is ff.

History, legal, $26 \mathrm{ff}$.

Huguet, 76 .

Huntiug laws, iro.

Indust rial a 1 urts, 12\% ff.

Indust rial propert $y^{\circ}, 55$ ff., 112

Infants, 52 ff.

Infant s' cont racts, 59 .

Inguisition, The, 141 .

Insanity, defense of, 100 .

Insolvency (Bk. IV, Cons. Code), 65

Institutu de Ibcro-Americane, zo.

Instituto nacional de prevision, $1=0$.

Instituto the reformas sociales, izo ff.

Int numcrotos piblicos, so.

Insurance (13k. I1, Cont. Corle), is ff.:

Accident, $\mathrm{I}=3 \mathrm{ff}$

litelustrial, :o. 
Insurance-Continued.

Iive, 75 .

Land transportation, 75 .

Life, 75.

Maritime, $7 z$

Old-age, 127 .

Sickness, 126 .

Workmen, 123 ff.

Intellectual property, 55 fi., 112.

Interiational law:

Public int. law, $130 \mathrm{ff}$

Conflict of laws, r3.3. $\mathrm{ff}$.

Intestate succession (Bk. 111, Civ, Cinde) , 46.

Itrigation, 1 I5

I cabella, 33.

Jacobs, 7.

Janer, 130 .

Jeronimo Feijo, 22.

Joint owners (Bk. II, Civ. Cude), $4^{\text {h }}$

Jolnuston, 50

Jovellanos, 2 r.

Judicial decisions, I 2 ff

Judiciary act, $8_{3}, 8_{7} \mathrm{fr} ., 97$.

Juicios athit rales, 8.4 .

Juris, 17 .

Jurispridence, is ff.

Jurispnudencia, $12 \mathrm{ff}$., in ff.

Jurisprudencia del Día, La, I4.

Jury, $97,100 \mathrm{ff}$.

Justinian law, 33 .

Kindasvinth, 25 .

Kirchevlueim, s,

Kuletrann, 128 .

Labor contract, 121 .

I.abur disputes, 127 ff.

I abor legislation, I2o ff

I rabor organizations, $I \geq 8 \mathrm{fi}$.

Labra:

Cuestiones, 138 .

Instituto de der. int., $13 \mathrm{r}$.

Reforna politica, 238 .

I. a Coste, 58

I.a Fuente, I4I

Laget, L. and $\mathrm{V} ., 94$.

I,and registration, is

Landa, 132 .

I.ands, colonial, 139

I.ands, waste, 63.

Langle, Rubio, 96.

1, a Publicidad. 3.3

I.ast res:

Actos fle comercio, :o

Filiacion, 52 ,

Foreign corporations, 135

Matrintonio, 52 .

Operaciones de bolsa, , $r$.

Penitenciarios, 108.

Procedimientos, 86, 99.

'Tuteta y' coinsejo de familia, 52 Law reviews, 17 .

Law schools, 10

Lawyers, 19 .

I,ea, 118 .

Leases, 60 .

Leases, contract of (Bk. IV, Civ. Code), $4 \%$

Lecanda, 43

I. cgal education, ro.

Legal history, $26 \mathrm{ff}$.

I.iger, $1 \geq 4$.

Legislation, $9 \mathrm{ff}$.

Lelir, so.

I,eve;, 3 s, 4 s.

Lex romana visigotlurunt, 27

Lex wisigothorm, 28 .

Ley hipotecaria, $60 \mathrm{ff}$.

Leyes del estilo, 3 I.

l,eyes de Indias, $34,136,737$.

Leyes nuevas, 31

Liber gothorum, 28

Liber judicum, 28 .

I.ibtu de las leyes, 32 ff.

I imitations, statute of ( Bk. IV, Civ. Code: Bk. IV, Com. Cole) $47,65,81,100$ (crimes).

Linares, 113 .

Literary ptoperty', $55 \mathrm{ff}$.

I, lamas, 33 .

Llanas Aguilaniedo, 10\$.

Loans (Bk, IV, Civ. Code; Bk. II, Com (ide), 47,60,65.

Loans on real estatc,

Lobingier:

Breach of promise, 52.

Fueso juzgo, 29

Siete partidas, 32

Sparish object lesson in code making, 38 .

Lombroso, 107

Lopez, F. I 28

López, G., 32

Iópez, I niantes, roo.

I,opez de Lago, 43

I,ópez Medina, 116 .

Iopez Muran, 45.

I.ópez Moreno, \$6, 99

Iópez Nunez:

Infancia, 126.

Previsión, 229

Iópez de la Osa, 45

Iónez Pálaez, r4o.

Lnlio. 20.

Majority (Bk. I, Civ, Code), 46.

Malloy's Treaties, $8,131,135$.

Miluquer y" Salvaclor, 79.

Naluquer $y$ Viladot, $7 \mathrm{r}$.

Malldvatto, I 7

Manjoin, 1.70

Manresa:

Comentarios al cioligo civil, to

Conentarios a la ley enjuicianiento civil, 85 
Manrichulatr, 30, $3^{8}$.

Minriqua, $30,3 \mathrm{~K}$.

Manuel y Rexlrignes:

fiuese viejo y otros cidifos, 30, 32. Institutes, 50

Maps, 5.5 .

Maraniot:

Collections of laws. 18.

Hacienda priblica, as

leyes andminist retivas, $1 \mathrm{r}$.

I.ejos civiles, 4 , 60 .

Lezes notariales, 90.

leyes punales, $24,98,104$.

Mirfi, 20.

Maria cumbrontero, 39.

Mariana, so.

Mariu, 132

Maritune int. law, $; 9,133$.

Maritimc law (Bk.11t, Com. Cole), 05,7717 .

Maritime nortgage, $64.77 \mathrm{fT}$.

Market-overt, 7o.

Marriage ( $\mathrm{Rk}, \mathrm{I}, \mathrm{Civ}$. Corle), $4^{\mathrm{h}}, 52 \mathrm{ff}, \mathrm{iq1}$, 142.

Marvaud, izs.

Martin-Cramero, 75.

Martinez Acacio, 52.

Martinez Alcubilla:

Códigos antiguos, 35 .

Código civil, $4^{\text {s. }}$

Diccionario, 10, II2,

Martincz Marina:

Ensayo historico, $30,3 \%$.

Teoria de los cortes, $2 \mathrm{I}$.

Martinez Moreda:

Diccionario, 10.

Levislacion hipotecaria. 62

Martinez Ruiz, 107.

Nartorcll, so.

Mas, IAI,

Mascarell, I28.

Maura:

Legislacion fortil, .4.

Propiedad de rersonas juridicas, 55.

Maurtua, 13s.

Medina liernáudez, tr.

Medinal, I..:

Collection of titws, Is.

Haciendis publica, I Is.

rejes administrativas, i it.

Leyes civiles, 49,00 .

Lejes notarjales, 90.

Leyes penales, 94, 95, 104

M ejora, 58

Melgat, $5 \mathrm{~s}$

Melgares Marin, I.4I.

Mendez de Vigo, ItS.

Mentez, 45 .

Mercantile register, of. oy.

Mercluants marine, $0_{3}$.
Merchints, 0,4

Metholology, 25.

Minul Morcho. so.

Military eriminal lak 103 ff

Military service. 105.

Miñanı y Vill.ı: ta\a:

Codigus de comercios, 68.

Códino de comercio espanol, $f(x$,

Minerals (13k. 11, Civ. Code), $4^{\text {f. }}$

Mines, $112,110 \pi$

Minors, : 2 fT.

Miracle de Curlonell, I4I.

Misemeanors, oz.

Models, sfo.

Montero, $\mathrm{ir}$.

Moutes, $10 ;$

Mora. $7 \%$.

Morales y Alonso, r.so.

Morales y Cónucz, 43.

Morejo y Lorenzo, 7h, 105.

Moret, $x=0$.

Murtgage lnank, 64, 72 .

Mortgage, maritime, 6.4.

Mortgayes, 60 ff.

Mortmain, 54.

Moses, 136 .

Moslem rule, 20.

Moutón:

Diccionario, 44 -

Fertocarriles, 74 .

Mühlbrecht, $s$.

Municipal adninistration, :13 fr.

Municipal justice, law of, 87 .

Murillo, 13\%.

Musical works, 55 .

Mutuil benefit societies, $12 \%$

Narregui. 43 .

Nationality", 13..

Naval courts, jo $\mathrm{ff}^{\mathrm{f}}$.

Negutiable instruments (Bk. II, Cinn.

Coile) $65.76 \mathrm{ff}$.

Negrin, :9, 133.

Neokintian pluilusoplyy of liaw, 26 .

Nidu:

Accilentes de trabajo, 12to.

Justicia milit.ır, I 14

Noguer, : $:$

Nogutes, so.

Doncontentions jurivliction, \& $\mathrm{ft}^{\circ}$

Nontesident litivants, $2 \pi$.

Notarivl luw, suff.

Nitary public, so, ff.

Novarro Filures, 26 .

Novisima recergilation, $31,34 \mathrm{fr}$.

Noyoa, go.

Nueva tecopilacion, $31,33 \mathrm{ft}$.

Nys, 131.

Obligations (Bk. IV, Civ, Conle), $4 \%, 47,54 \mathrm{ff}$,

Odriozula, 6. 
Olivart:

Bibliographic, I3I.

Derecho int. priblico, 133 .

Revista de der, int., ${ }_{33}$.

Treaties, $8_{3}, 130$.

Oliver Estellar, 62.

Oliver Rodriguez, io.

Olmeda, 132 .

Ordenamiento de Alcalá, 30, 32.

Ordenamiento real, 33,35 .

Ordenanza de Bilbao, 32,63 .

Ordenanza de Castilla, 3 r.

Orti y Lara, 23

Otcro, 59 .

Ouwerx, 7

Ow nership (Bk. II, Civ. Code), 46.

Oy'uelos:

Accidcutes de trabajo, I 26.

Association for legal protcction of laborers, $1 \geq 2$.

Pachicco:

Cörligo penal, 95.

Comentarios de las leyes de lori, 33 . Jurado, ror.

Faintings, 55.

Pantoja:

Jurispntdencia adm., 15

Iurisprudencia civil, 14.

Jurisprudencia criminal, I5.

Paraplsema (Bt. IV, Civ. Code), 47.

Parcel post, 73 .

Parent and thild (Bk. I, Civ. Code), 46, 52 ff.

Parral, 42.

Parreño, 78 .

Partidas, siete, $3 \mathrm{I}$ fi, 35.

Partnership (Bk. IV, Cir. Code; Bk. II,

Cum. Corle), $47,64,72 \mathrm{ff}$.

Passcugers, 73.

Pastor y Bustos, 67 .

Patents, 55 ff, 83 .

Patcraity (Bk. I, Civ. Code), $4^{\text {th, }}, 2_{2}$ fit.

Pedregal:

Consuctudinario Dercho, 45 .

Mrmicipal Lerecho, I13.

Pedict, i6.

Pella:

Los fueros de Cataluina, 43 .

Patentes, 57.

Pellicer, 18 .

Penal corle, $92 \mathrm{fi}$.

Ponichet, 54.

Penitenciaria, revista, 108.

I'ensions, 105, 127.

Peral, II8.

Periodicals, legal, I.

Perkins, 121 .

Persons (Bk. J, Civ, Code), 4 h, 52 ff.

I'essina, 96 .

Philip II, 33.
Philosophy of law, $x_{9} \mathrm{ff}$.

Pieralas Hurtado:

Consuctudinario, 45.

Hacienda pública, irs.

I'icruas $y$ de 'Tineo, 58.

I'ipoll, 43 .

Pirquer, 104.

l'ledge (Bk, IV, Civ, Code), 47.

Pons, III.

Peor laws, ing, Izo.

I'ort of refuge, 77

Ports, ir2.

I'osada:

Dercclio administrativo, I10, 112 .

Derecho politico, I Io.

Derecho politico comparado, ro.

Derecho usual, 8, 18, 121 .

Gría, r1o.

Jurisprudence, 26 .

Regiment local, 114 .

Spanisches staatsreelit, itr.

Possession (Bk. II, Civ, Code), $4^{\text {ho. }}$

Irats, ins.

Preceilents, 12 .

I'refercuce (Bk. IV, Civ, Code), th.

Prescription (I3k. IV, Civ. Cude; IBk. IV,

Com. Code), $4 \% 65$.

Press, Association of the, 55 .

I'robation, 102.

l'rocedure:

Bankruptcy, 8 .

Civil, 83 ff.

Commercial cases, 84 .

Criminal, $97 \mathrm{ff}$.

Ecclesiastical courts, 86.

Military courts, 86, $103 \mathrm{ff}$.

Senado Trials, S6.

I'roperty (Bk. II, Civ. Code), $46,54 \mathrm{ff}$.

Froperty, registration, ug.

Protection of ind ust rial prizes, 56

Provincial administ ration, I 33 .

I'rudhomme, 66.

Fublic charities, 112.

Fublic law, $109 \mathrm{ff}$.

I'ublic service companies (Bk. 1I, Com.

Code) $, 65,73 \mathrm{ff}$.

Public works, 11\%.

Fuig Martínez, Iz8.

Purchase of foreign ships, 63.

Puyol, 123.

Quasi contracts (Bk. IV, Civ. Corc), 47, $59 \mathrm{fi}$.

Raikes, 77.

Railroad police regulations, $73 \mathrm{ff}$.

Railway's (Bk, 1I, Conl. Corle), 65, 73 ff., II2.

Ramclki, 5 \%.

Ranus:

Contratus de menores, 5.3. 59

Crélituagricolo, i2. 
Ramos-Continued.

1.c.islaciin, ir.

I'renda agricula, 62

Siucesiones, $5^{8}$.

Recopilación de Indias, 136,137

Recolvilación, novisima, $3 \mathrm{I}, 34 \mathrm{ff}$

Recopilletion, nueva, $34,33 \mathrm{ff}$.

Recurding of property, 1 ing.

R. IV. V.., 98

Redondo, st

Refonns of criminal haw, 9z, 106 ff

Re'pist ration of property (13k.11, Civ. Code), $4^{6,119}$.

Registo (I3k, 1, Conn. Cole) $64,68$.

Rexistry of civil status (Bk. I, Civ. Corle), 46,54 .

Relatives, mantenance of (Bk. I. Civ.

(ioje), $46,5=\mathrm{ff}$

Reniolifue, 78 .

Renaissance, zo.

Rents (Bk. IV, Civ. Colc), 47,60 .

Rcus, 86.

Revista de derecho intemacional, $\mathrm{r} 33$.

Revista de dereche privado, 8,17

Revista gemeral de legislación y jurispru-

dencia, $8,12,13,17$.

Revista de los tribunales, $18,1.4,17$.

Ribera Cuñizares, 54 .

Rius, C., 56 .

Rios Urruti, 26

Riquelue, 132.

Rives:

Acreedores, $\mathbf{S}_{\mathbf{I}}, 86$

Fnjuiciamiento civil, $8_{5}$

Juzgados municipales, 88.

Rodriguez, A., SS.

Rodriguez Jiménez, 10.4

Rolriguez Alartin, 114.

Rodriguez l'inilla, ror.

Rodriguez San Pedro, 137.

Rodrigucz Serra, in.

Roman rule, 27.

Romero y Delgado, go.

Runcro y Girón, $x 7$

Romero Villanucva, s05.

Ruscher, 136

Rosscllo, 57

Rovirit, 90

koyo Villanovas, 112

Rubita, 134

Ruie y Gil, 78 .

Ruiz (Max Bembo), 108.

Sauvedra Fajarto, zx.

Sacoz-11 urmüa, 15.

Sainz de Andino, 63

Saiz y Gümez, 102

Silillas, 108,123

Sánchez y Jiménez, 116
Sunchez de Ocaña:

Censos, 60.

Jurado, ror.

Justicia niilitar, so.4.

Minera, 117

Organizacion judicial, 88

Sántcluez kirna:n, 40, 50 ff, 59.

Sant Isidero, zo.

Santunaria de Paredes:

Jerecho arlninistrativo, 112

Derccho consuetudinario, 45

Derccho politico, no.

Jurispradence, 26 .

Sanz 3 Caminalo, I15.

Sanz y Escarta, rzz.

Sinz elel Rio, 23.

Sastre, 75 .

Seaevola:

Cúdizo civil comentado, 49.

Jurisprudencia, $5 \mathbf{r}$

Schmidt, 8, 37. 50 .

Schofictul, 103.

Schools, law, 19.

scutt:

Criminal law, 93

Penal code, 93.

Siete partidas, 32

Visigothic corle, 29.

Security (Bk, IV, Civ. Cole), 4 .

Scla, IS, 12s.

Sempere, 37.

Sentence, suspended, roz.

Sentencias, iz ff.

Septenario, 3 r.

Serrano, 45.

Service of judicial process, 9I.

Servitules (Bk. II, Civ. Codle), 46.

Shippint (Bk. Ill, Com. Cule), 65.

Shipwrecks, 77.

Sickness insurance, 126

Sicte particlas, 3 I ff.

Silvela, F., 40.

Silvcla, I., 95.

Silvela, Loring, \$6, 99.

Simancas, 121 .

Singer, 56 .

Smith, 13 ho.

Secicty of authors, 55 .

Solcr, Is

Sulozano, ${ }^{3}$ s

Soriano, 45

Suto, D., 131 .

Sinto yernindez, 55 .

Status, civil (Bk. I, Civ. Code), $4^{6}, 54$.

Statute of limitations, $47.65,81,100$ (crimes).

Strock exchanges, 68, ;o ff.

Stwequart, 52

Strikes, 128 .

Suarez, F., 20, 131. 
Suarez, Victoriano, 8. Succession of property (Bk. III, Civ. Code) $46.58 \mathrm{fl}$.

Sucesiones (Bk. IfI, Civ. Code), 4 ti, $55^{8}$ if Sumario (Bk. I1, Crinl. proc.) 97, ror 1 . Sunday labor law, rzg.

Support of relatives (Bk. I, Civ. Corle), $4^{t}$, $52 \mathrm{fl}$.

Supreme colurt, 12.

Supercargoes, 77 .

Suspended sentence, ro:

Suspension of payment (Bk. IV, Com. Code), $65,79 \mathrm{fl}$.

Tapia, 78 .

'Taritis, I 8 ff.

Taxes, $118 \mathrm{ff}$.

Telegraph, 73,83

Telephone, 73 .

Teufilo, 67.

Testamentary succession (Bk. III, Civ. Code), 46 .

Theurault, 98

Tickets, r. r., 73.

Torino, 74.

Torre y Iyquierdo, 9 .

'Torres y' Aguilar, 38.

Torres Ballasté, $\mathbf{6} 6$.

Torres Campos:

Bibliografia, 7 .

Derecho int. privado, 134.

Derecho int. público, 133.

Foreigners, I34.

Pena de mueste, 102.

Staatsrecht, iा I.

Towage, 78 .

Trade-marks, $55 \mathrm{f} ., 8_{3}$.

Trade names. 56,68.

Tranvias, it ff.

Trapaga

Justicia militar, $\mathrm{r}_{4}$.

Servicio militar, 105.

'Traveling salesmen, zo.

Treaties, $130 \mathrm{ff}$.

'Trias, 42.

Tribunal supremo, 12.

'Tridon, rqo.

Ubierna, 12 .

Ugate, 88 .

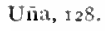

Unamuno, $\dot{q}$

Unfair competition, 56 .

Unions, labor, I 28 .
Universal conventions, 83 .

Ureña:

Historia de la literature juridica, $\because, 30$

La influencia semita, 29.

Use (Bk. II. Civ. Code), $4^{6 .}$

Useful models, 56 .

Usuiruct ( $\mathrm{Bk}$. II, Civ. Code), 40.

Valdés Rubio, 96.

Vallés, :o.

Valverde, $5 \mathrm{I}$

I. A. AI. 5 I.

Varón y Caballero, 108.

Vazquez y López, I4t.

Vazquez Manchaca, 21.

Verdegay, 75 .

Verdier, 98, 101.

Viada, 95.

Viceroy, 136 .

Vila Serra:

Collection of laws, 18 .

Hacienda puibluca, IIs.

Hipotacarios, 61.

'r rabajo, 122 .

Villa, is 8 .

Vallalobos Iópez, 58 .

Villa y Peralta, 53.

Villar Grangel, I $_{3}$.

Vipegon, ror.

Visigoths, 27.

Vitoria, 20, I3 1 .

Vives, 20.

Voluntary jurisdiction, $s_{4} \pi$.

Von Tbót, 92.

Walls, 35 .

Walton:

Civil code, 47.

Civil law, $36,50,199,137$.

Leyes comerciales, 66 .

War, rishts of, $130 \mathrm{fl}$.

Wraters (Bh. II, Civ. Cule), $46, t_{2}, \mathrm{rr}_{5} \mathrm{fl}$.

Wistlake, 132.

White, I 19,139

Nidows, 105.

Wills, $58 \mathrm{ff} ., \mathrm{r}_{4} \mathrm{r}$.

Women, 53.96, 129

Workmen's compensation act, I $23 \mathrm{ff}$.

Workmen's insurance, $\mathrm{I}_{23} \mathrm{ff}$.

Yanguas, 43.

Zaragoza, 88 .

Zarzoso, 90.

Zeumer, 29 .

Zurita, Nicto, yo. 




DATE DUE

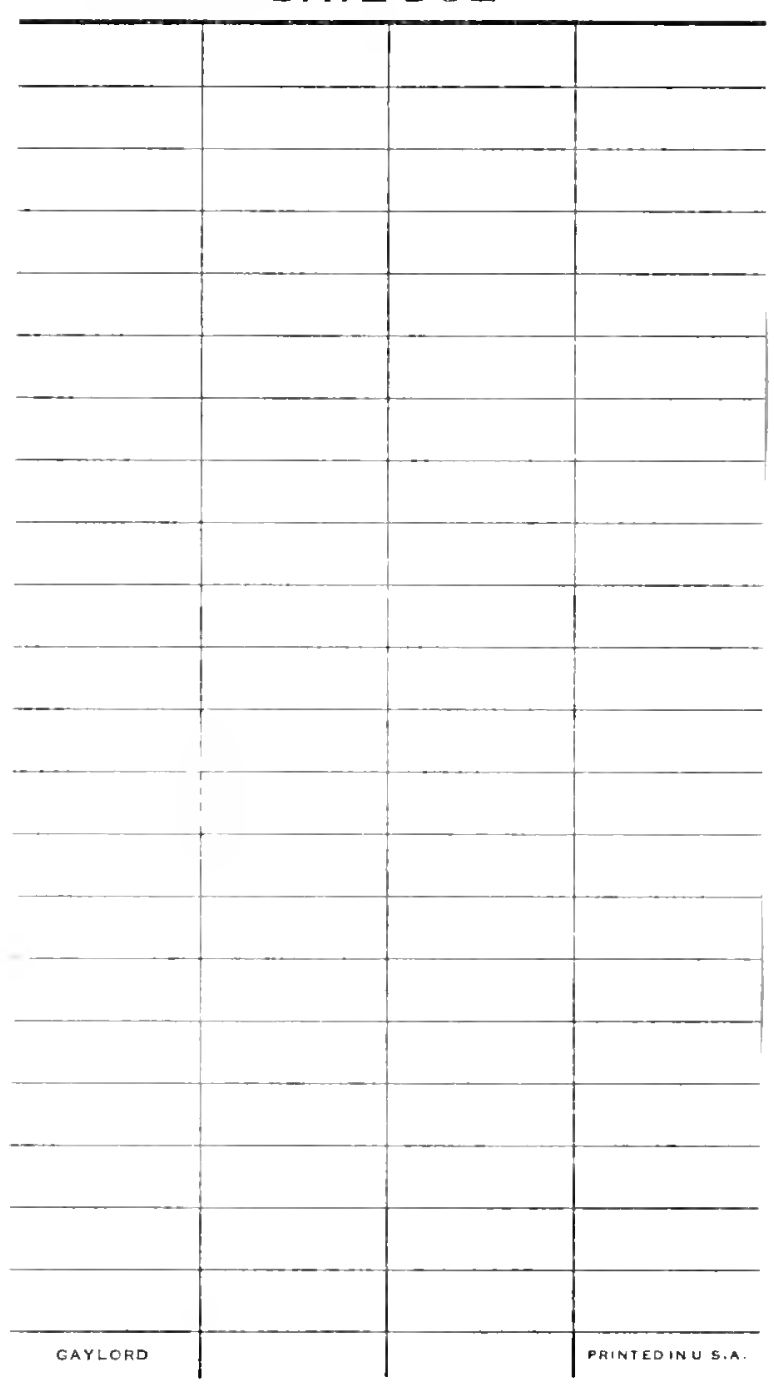




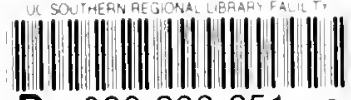

D 0003986510 
